\title{
TWENTY-ONE THESES ON THE LEGAL LEGACY OF THE FRENCH REVOLUTION IN LATIN AMERICA
}

\author{
Dante Figueroa*
}

\section{TABLE OF CONTENTS}

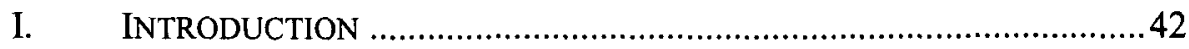

II. A TWISTED NOTION OF NATURAL LAW …………..........................48

A. Elimination of Divine Law from the Hierarchical Pyramid Presented by Thomas of Aquinas ...............................................5 50

B. Natural Law Is No Longer Unchangeable, Universal, or Permanent

C. Elitist, Moralistic, and Moralizing Ethos Tainted the Concept of Natural Law....

D. The People Do Not Reserve Any Powers: All Are Transferred to the Majority As Represented by the Legislature

III. A Total AND Rigid SEParation Of RELIGION AND State...........54

A. Religion Has No Role in the Public Square ................................54

B. Social Justice Is a Secular Concept to Which Religious Views Are Alien .56

IV. Positivism AS A MORALLY-NeUtRal LegisLative SYSTEM .........57

A. No Role for Stare Decisis ......................................................57

B. The Truncated Role of Custom .................................................5

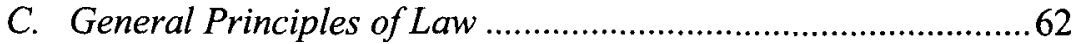

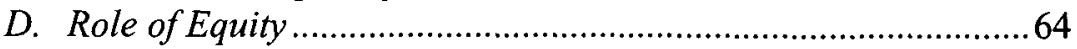

V. Promotion of THE DEMOCRATIC SYSTEM OF GOVERNMENT AS THE SUPREME FORM OF GOVERNMENT....................................66

* Dante Figueroa is an Adjunct Professor at the Georgetown Law Center and the American University Washington College of Law. He holds LL.M. degrees from American University and University of Chile law schools. He can be reached at df257@georgetown.edu. 
VI. CONCEPT OF ABSOLUTE STATE SOVEREIGNTY AND EXALTATION OF NATIONALISM 70

VII. DOCTRINE OF STRONG SEPARATION OF POWERS 71

VIII. ABSOLUTE SUPREMACY AND MONOPOLY OF THE STATE CONCERNING LEGISLATION 73

IX. LACK of CONSTITUTIONAL EMERGENCY POWERS .75

X. DIMINISHED ROLE OF THE JUDICIARY .80

XI. WeAK AND TROUBLED SySTEM OF JUdiCIAL REVIEW. .82

XII. Legislative Process Conceived As a Rational AND SCIENTIFIC ENDEAVOR DETACHED FROM PRACTICAL CONSIDERATIONS. 84

XIII. CODIFICATION AS AN INSTRUMENT FOR BROAD GOVERNMENTAL CONTROL OF SOCIETY .86

XIV. PROMOTION OF A DYSFUNCTIONAL SYSTEM OF CRIMINAL LAW AND PROCEDURE. .88

XV. A CiVIL Procedure MESHED WITH Rigidities AND INCONSISTENCIES. .95

XVI. A CIVIL CODE MARRED WITH INCONSISTENCIES AND INSTRUMENTAL TO A NOTION OF SOCIETY THAT BENEFITS THE FEW TO THE DETRIMENT OF THE MANY

XVII. Promotion OF THE INDIVIDUAL As THE MEASURE OF ALL THINGS

XVIII. L'ORDRE BOURGEOIS: MUCH FOR THE FEW, LITTLE FOR THE MANY

XIX. Unleashing the Idea That THE SeXual Conduct of THE Citizen Is a Purely Private MATTER

XX. ABolition of INHERITANCE SCheme Facilitated DeEP RESENTMENTS AT THE FAMILY AND SOCIETAL LEVELS 
XXI. Imposition Of A STATE Doctrine BaSEd ON THE PRINCIPLE OF UNIVERSALLY-MANDATED GOVERNMENT EDUCATION

XXII. A LEgaL PROFESSION WITH LOOSE ETHICAL STANDARDS AND LAX ETHICS CONTROL MECHANISMS.....................................115

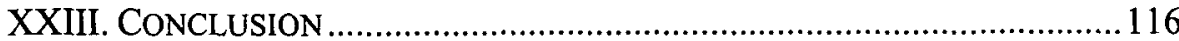


Terror is nought but prompt, severe, inflexible justice; it is therefore an emanation of virtue; it is less a particular principle than a consequence of the general principle of democracy applied to the most pressing needs of the fatherland.

-Maximilien Marie Isidore de Robespierre ${ }^{1}$

\section{INTRODUCTION}

The purpose of this Article is to present twenty-one theses involving the negative influences, in the view of the author, that the French Revolution has had on Latin American legal systems since the time of their independence. These propositions do not exhaust the respective topics, since each of them could be the object of a standalone tractatus (treatise). Instead, these propositions aim at motivating further academic discussion on the positions presented.

The methodology chosen consists of the proposition of twenty-one theses, each presenting a negative diagnostic of the effects triggered by the French Revolution's legal legacy in the life, organization, and essentials of Latin American legal systems. These theses revolve around five areas of impact: the ethical and philosophical substratum of the political system, the fundamentals of the democratic regime, the organization of the branches of government, the paradigms of fairness, justice, and axiology, and the shaping of family life, public morals, and the legal profession.

The Enlightenment and the French Revolution of 1789 were crucial historical and political phenomena that have significantly impacted European life $^{2}$ from the nineteenth century onwards. ${ }^{3}$ France was the epicenter of this philosophical, economical, and political cataclysm. The Enlightenment and the French Revolution served as powerful movements that embodied philosophical ideas that shaped societies and legal systems around the world. Even the American Revolution has been counted among the French

\footnotetext{
${ }^{1}$ See generally Maximilien Robespierre, Speech to the National Convention: The Political Philosophy of Terror (Feb. 5, 1794), available at http://www.worldfuturefund.org/wffmaster/ Reading/Communism/ROBESPIERRE\%27S\%20SPEECH.htm.

${ }^{2}$ See H.G. Koenigsberger \& Asa Briggs, a History of Europe: Early Modern EUROPE 1500-1789, at 315-31 (1987) (reviewing the immediate historical events leading toward the French Revolution).

3 James G. APPle \& Robert P. Deyling, A Primer on the Civil-Law System 13 (1995),

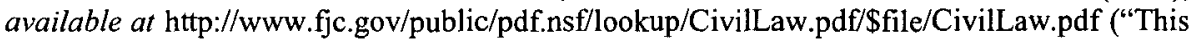
intellectual movement included the French Revolution and contained the near origins of the modern European codes.").
} 
Revolution's progenies. ${ }^{4}$ This influence had a particularly strong impact on the design, organization, implementation, and ongoing status of Latin American legal systems ${ }^{5}$ since the wars of independence. ${ }^{6}$ Many people generally recognize that the French Revolution changed the world, and that we are still living under its massive philosophical, intellectual, and legal influence, especially in Latin America. ${ }^{7}$ French revolutionary ideas are still profusely quoted in judicial decisions throughout the region. ${ }^{8}$

In effect, when the new Latin American republics gained their independence, they needed models on which to base their new societies. ${ }^{9}$ The fathers of the new Latin American nations were well aware that they were building on the remains of three hundred years of lberian influence, which was paramount in every sphere of colonial life. The Latin American liberators strongly rejected the Iberian legacy, even though most of them had obtained their education and training in the continent. ${ }^{10}$ They were quick to

${ }^{4}$ The resemblance of many provisions of the French Revolutionary Constitution of 1791 to the U.S. Constitution is noteworthy. Compare 1791 Const. tit. III, ch. V, para. 9 (Fr.) (providing that "[n]o citizen may be tried in criminal matters except upon an indictment received by the jurors"), with U.S. CONST. art. III, $\S 2$ (stating that "[t] he trial of all crimes ... shall be by jury"). Many other provisions of both constitutions show a striking resemblance, including the provisions on impeachment. Compare 1791 Const. tit. III, ch. III, $\S 1$ para. 10 (Fr.) (delegating the legislative body with "[p]rosecution, before the National High Court, of the responsibility of ministers and of the principle agents of the power"), with U.S. CONST. art. I, $\S 3$ ("The Senate shall have the sole Power to try all Impeachments."). Also notice Title III of the Constitution of 1791, where, "[o]f Public Powers" first regulates the "National Legislative Assembly." Article I of the U.S. Constitution follows suit by referring to "[t]he Legislative Branch."

5 Robert S. Barker, Judicial Review in Costa Rica: Evolution and Recent Developments, 7 Sw. J.L. \& TrADE AM. 267, 269 (2000) ("The independence movements in Spanish America were strongly influenced by the French Revolution.").

${ }^{6}$ IVÁN JAKSIĆ, ANDRÉS Bello: SCHOlarship AND NATION-BUILdING IN NINETEenthCENTURY LATIN AMERICA 156 (2001) (recalling that the Chilean Liberator, Bernardo O'Higgins, proposed the wholesale adoption of the Code Napoleon in 1822 to the Chilean Congress, accompanying his proposal with the following exhortation: "Let us forever erase the institutions built under colonialism and eradicate ignorance!").

7 Apple \& DeYling, supra note 3, at 18 (referring to the Civil Code of Brazil as the "greatest monument to legal thought and codification in Latin America" and also pointing out that "[t]he greatest influence on this code's substantive provisions was the Code Civil of France").

${ }^{8}$ See Sentencia [S.] No. 504, de las 5:00 p.m., 19 Oct. 2009, Boletín JudiCial [B.J.] [Supreme Court of Justice] pp. 1-23, Cons. VIII (Nicar.), available at http://www.glin.gov/vi ew.action?glinID=224071 (allowing the President of the Republic and other public officials to run for reelection).

9 Dale Beck Furnish, Judicial Review in Mexico, 7 Sw. J.L. \& TRADE AM. 235, 237 (2000) ("Mexico's legal system traces its lineage from the Romano-European traditions of the Civil Law, through the French Civil Code of 1804.").

${ }^{10}$ See generally allan R. Brewer-Carías, Reflexiones sobre la Revolución NORTEAMERICANA (1776), LA REVOLUCIÓN FRANCESA (1789) Y LA REVOLUCIÓN 
reject the Spanish influence, and gladly embraced French revolutionary ideas $^{11}$ that ended up shaping the new Latin American legal systems. ${ }^{12}$ The French Revolution had a great impact not only on private law (civil law), but also on public law, as it became the intellectual mother of the Latin American independence movement.

More than two hundred years have helped to assess the impact of the French Revolution in the Latin American legal field. The common claim that it constituted a grassroots movement directed by, and for the benefit of, the people has greatly receded. A quick glimpse of Delacroix's Liberté Guidant le Peuple (Liberty Leading the People) - even though painted forty years after the Revolution-clearly reveals the truth behind the July cataclysm: ferocious bourgeois faces trampling upon the fresh cadavers of scantly dressed, destitute people. ${ }^{13}$ The true owners and harvesters of the revolutionary horrors were the leaders of the aristocracy and the nobility. No independent and learned observer in his compos mentis (sound mind) may deny the outright connection between the Revolution, the Reign of Terror, ${ }^{14}$ and the Napoleonic imperial experiment. ${ }^{15}$ The real forces behind the Revolution appealed to the liberal idea of representative democracy to cloak their efforts with a blanket of legitimacy. However, what really happened is that the enlightened and despotic government of the bourgeoisie replaced monarchical government. ${ }^{16}$

HISPANOAMERICANA (1810-1830) Y SUS APORTES AL CONSTITUCIONALISMO MODERNO 155202 (2008) (analyzing the institutional crisis that led to the French Revolution prior to 1789, and its impact on Latin American early constitutionalism).

11 M.C. Mirow, The Code Napoleón: Buried But Ruling in Latin America, 33 DENV. J. INT'L L. \& POL'Y 179, 183 (2005) (stating that '[a]part from the intrinsic appeal of the Code and its widespread acceptance within world legal circles, its Frenchness made it particularly attractive to Latin Americans in this crucial period of Latin American codification").

${ }^{12}$ Id. at 181 (stating that " $[\mathrm{t}]$ he fundamental influence of the Code Napoléon on Latin America's legal development is unquestionable and clearly evident from contemporary sources").

${ }^{13}$ Eugéne Delacrodx, July 28: Liberty Leadng the PeOPle (1833), available at http:// www.louvre.fr/llv/oeuvres/detail notice.jsp?CONTENT\%3C $\% 3$ Ecnt id $=10134198673237674$ \&CURRENT_LLV NOTICE\%3C\%3Ecnt_id=10134198673237674\&FOLDER\%3C\%3Efolder id=9852723696500815\&bmLocale=en; see also CHARLES BAUDELAIRE, EUGËNE DELACROIX: HIS LIFE AND WORK 30 (1979) (mentioning that Delacroix called himself "a realist" in the presentation of his own art; "Je veux représenter les choses telles qu'elles sont") ("I want to portray things such as they are." (author's translation)).

14 Charles Hill, Grand Strategies: Literature, Statecraft, and World Order 24 (2010) ("The French Revolution ideologically legitimized terror."). For a further analysis of the terror, see generally Hugh GOUGH, THE TERROR IN THE FRENCH REVOLUTION (1998).

15 See generally Napoléon Bonaparte 1769-1795, FRENCH-AT-A-TOUCH.COM, http://www.fr ench-at-a-touch.com/French_History/napoleon_i_1769-1795.htm (last visited Mar. 20, 2011) (providing a chronology of French History).

${ }^{16} \mathrm{Id}$. 
This Article argues that the legal ideas advanced by the Enlightenment and the French Revolution, which influenced the new Latin American nations during the nineteenth century, were not random, unsystematic, or haphazard. To the contrary, the premise is that those ideas were materialized by, and in turn coherently advanced by, a fully coordinated philosophic thinking that was (and is) consistent and compact. The beheading of King Louis $\mathrm{XVI}^{17}$ by the National Assembly in 1793 set the tone for the guillotining of about forty thousand under the Reign of Terror. ${ }^{18}$ As a consequence of the influence of the French Revolution, many more perished during the subsequent Latin American political experiments. ${ }^{19}$ All things considered, the Revolution was true to itself - blood is what it got:

To arms, citizens!

Form your battalions!

Let us march, Let us march!

May an impure blood

Water our furrows! ${ }^{20}$

This Article asserts that many of the chaotic consequences that plague Latin American legal systems in the eyes of common law observers were avoided in England, since England "steadfastly steered its traditional course." 21 That is, England did not have an event equivalent to the French Revolution. $^{22}$

The key legal notions brought about by the Revolution include: the absolute separation and antagonism between religion and the State, ${ }^{23}$

17 André Tunc, The Grand Outlines of the Code Napoleon, 29 TuL. L. REV. 431, 431 (1955) (noting that "if there was great confidence in the justice of the King, the confidence was often less in the royal officers and even in the royal judges").

18 See generally RoSe MCCARTHY, DICTATORSHIP: A PRIMARY SOURCE ANALYSIS 18 (2005) ("Eighteen thousand people were executed at the guillotine, and more than 20,000 were killed by other means."); see also ANNE MARIE DUPORT, TERREUR ET REVOLUTION: NîMES EN L'AN II 1793-1794, at 245-84 (1987) (referring to Chapter II (A): "[l]es victims des lois révolutionnaires") ("the victims of revolutionary laws" (author's translation)); id. at 285-87 (containing bibliography on the subject).

19 See generally BENJamin KeEn \& KeITH Haynes, A History OF LATIN AMERICA 178-592 (8th ed., Cengage Learning 2008) (analyzing the bloody consequences that the multiples coups and dictatorships have caused in Latin American countries from the nineteenth century).

${ }^{20}$ Clause Joseph Rouget de Lisle, La Marseillaise (1792), available at http://www. ford ham.edu/halsall/mod/marseill.html.

21 R.C. VAN CaEnegem, AN Historical Introduction to Private Law 134 (D.E.L. Johnston trans., 1992) (1988).

${ }_{22}$ See id. at 137 (recalling that Latin was the official language of law in England until 1731).

${ }^{23} 1791$ CONST. pmbl. (Fr.) ("The law no longer recognizes religious vows or any other 
sovereignty of the State, ${ }^{24}$ the privileged and virtually unchecked legislative powers of the government, ${ }^{25}$ the unrestricted supremacy of statutory law, ${ }^{26}$ the restrictive role assigned to legal sources (custom, general principles of law, and equity) other than statutory (positive) law, ${ }^{27}$ the unification of civil laws in one legal body (the Civil Code) universally applicable to the whole nation, ${ }^{28}$ a diminished judiciary, ${ }^{29}$ the abolition of the intermediate corporate bodies of society represented by the guilds, ${ }^{30}$ the imposition of universallymandated government instruction, ${ }^{31}$ the abolition of the fundamental institution of Western family law ${ }^{32}$ and the consecration of a legal system guaranteeing privileges for the few to the detriment of the many. ${ }^{33}$

In light of these legal notions, this Article proposes that the twisted notion of natural law championed by the French Revolution-coupled with its ideas of authoritarian democracy, paternalist state, legislative monopoly and supremacy ${ }^{34}$ and the lack of an effective check and balances system-have all contributed to the systematic degradation and delayed demise of Latin American democratic systems. In turn, this Article sustains that these phenomena facilitated a poor human rights record throughout the region in the last two centuries.

obligation contrary to ... the Constitution."); $i d$. tit. I, $\S 3$, para. 9 (providing for the right to elect religious ministers, contrary to the Catholic Church's millenary clerical appointment process).

${ }^{24}$ Id. tit. III, para. 1 ("Sovereignty is one, indivisible, inalienable, and imprescriptible. It appertains to the nation; no section of the people nor any individual may assume the exercise thereof.").

${ }^{25}$ Id. pmbl. (remarking that all citizens are equal, and that there is no "superiority other than that of public functionaries").

${ }^{26}$ Id. tit. III, ch. II, $\S 1$, para. 3 ("There is no authority in France superior to that of the law.").

${ }^{27}$ See id. para. 6 ("If the King places himself at the head of an army and directs the forces thereof against the nation, or if he does not, by a formal statement, oppose any such undertaking carried on in his name, he shall be deemed to have abdicated the throne.").

${ }^{28}$ Id. tit. I, § 3, para. 13 (" $[\mathrm{A}]$ code of civil law common to the entire kingdom shall be drafted.").

${ }^{29}$ Id. tit. III, ch. V, para. 3 (manifesting that "the courts may not interfere with the exercise of the legislative power, suspend the execution of laws, encroach upon administrative functions").

${ }^{30}$ Id. pmbl. (" $[\mathrm{N}]$ either jurandes nor corporations of professions, arts, and crafts any longer exist.").

${ }^{31}$ Id. tit. I (mandating public instruction for all citizens).

${ }^{32}$ Id. tit. II, para. 7 ("The law considers marriage only as a civil contract.").

33 Id. tit. III, ch. I, \& 2, para. 2 (establishing requirements related to age, birthplace, and social position for the exercise of civil rights).

${ }^{34}$ Tom Farer, Consolidating Democracy in Latin America: Law, Legal Institutions and Constitutional Structure, 10 AM. U. J. INT'L L. \& POL'Y 1295, 1315 (1995) (observing the French origin of "legislative supremacy"). 
In the area of government organization, for example, this Article states that the revolutionary concepts of strong separation of religion and State, absolute sovereignty of the State, and unfettered nationalism all contributed to the shaping of endemically weak and conflicted constitutional systems in Latin America from the very beginning. In addition, this Article asserts that the recent Latin American reforms in the area of judicial review-some of them borrowed from France-have not removed the original stain of incongruence and insufficiency present in the initial borrowing from French revolutionary law.

The Civil Code of 1804 is said to "enshrine the principles of the French Revolution." 35 This Article explains that the political and legal notions that were written into the Code are essentially authoritarian. Consequently, these legal ideas produced a legal instrument-lofty in its pretensions of universality, flawed in its combination of diverse philosophical approaches, and filled with unsubstantiated commitments. These features created a $\operatorname{code}^{36}$ plagued with inconsistencies, and, contrary to its pretensions, wholly unholistic. These flaws have greatly contributed to a situation of legal confusion and, in many ways, an undeclared motivation to walk away from law and justice in broad sections of Latin American societies.

This Article sustains that the French Civil Code's merits-as they areare found in sections borrowed from Roman law $^{37}$ and the European ius commune (common law), as it was, through $1789 .^{38}$ Furthermore, this

35 James Gordley, Myths of the French Civil Code, 42 AM. J. CoMP. L. 459, 459 (1994).

36 David Gruning, Codifying Civil Law: Principle and Practice, 51 LoY. L. REv. 57, 57 (2005) (commenting that, for some, the Civil Code "represents the culmination of the Enlightenment's view of the law and of legislation").

${ }_{37}$ Raúl Lozano Merino, Address at the Proceedings of the Ninth Annual Conference on Legal Aspects of Doing Business in Latin America: New Approaches: Looking to the TwentyFirst Century, in Successfully Financing Operations and Projects, 11 FLA. J. INT'L L. 72, 77 (1996) ("The Napoleonic Code is often recognized as the paramount synthesis of the Romanist tradition, originating from the oldest tradition and then molded by the above mentioned schools and the liberal principles that marked a new era in the history of thought.").

${ }^{38}$ For a review of the influence of Roman Law in Europe and the emergence of the ius commune, which the French Revolution aimed to abolish, see generally MANLIO BELlOMO, The Common Legal Past of Europe 1000-1800 (1995); H.G. Keonigsberger, Medieval Europe 400-1500 (1987); EnNio Cortese, Le Grandi Linee Della Storia Giuridica Medievale (2000); Laura Solidoro Maruotti, La Tradizione Romanistica Nel Diritto EUROPEO (2001); BARRY NiCHOLAS, AN INTRODUCTION TO ROMAN LAW (1962); H.F. JOLOWICZ \& BARRY NiCHOLAS, HISTORICAL INTRODUCTION TO THE STUDY OF ROMAN LAW (3d ed. 1972); Charles M. Radding, The Origins of Medieval Jurisprudence: Pavia and Bologna 850-1150 (1988); Kenneth Pennington, The Prince and the Law, 1200-1600: Sovereignty and Rights in the Western Legal Tradition (1993); James MuldoOn, PoPes, LaWyers, aND INFIDELS: The ChURCH AND the NON-Christian WoRld 1250-1550 (1979); R.H. Helmolz, The IUS COMmune in England: Four Studies (2001); van CAENEGEM, supra note 21. 
Article proposes that additions after 1789 have not or will not withstand the passage of time-in spite of widespread statements to the contrary-as two hundred years of history demonstrate.

Finally, this Article argues that traditional Latin American civil and criminal procedures, insofar as they borrowed from French revolutionary law, were inspired by the same flawed ideas as the Civil Code. Accordingly, these notions have contributed to promoting the widespread perception that Latin American civil and criminal procedures are utterly dysfunctional.

\section{A TWISTED NOTION OF NATURAL LAW ${ }^{39}$}

The concept of natural law ${ }^{40}$ was first proposed in the Western world by St. Thomas of Aquinas during the thirteenth century. ${ }^{41}$ The intellectual foundations of the West may only be understood by making a reference to the works of Aquinas, the great Catholic philosopher and theologian. He was the first to explain the triad constituting the foundation of all legal systems in the form of divine law, natural law, and positive (or human) law. ${ }^{42}$ Doctor Angelicus ${ }^{43}$ taught that divine law is the permanent set of rules emanating from God Himself through Revelation, mainly in the Sacred Scriptures. $^{44}$ Divine law is, therefore, eternal, wise, incorruptible, and possessing all the attributes of Eternal God. ${ }^{45}$

39 William May, Contemporary Perspectives on Thomistic Natural Law, in ST. THOMAS aquinas \& The Natural Law Tradition: Contemporary Perspectives 113, 124 (John Goyette et al. eds., 2004) (referring to the distortion of natural law "in some times and cultures").

${ }^{40}$ See van CAENEGEM, supra note 21 , at 115-21 (discussing the historical origins of the idea of "natural law").

41 Gordley, supra note 35, at 463-64.

42 See Peter J. Stanlis, Edmund Burke and the Natural Law, at xvii (2003) (explaining the Thomistic context of natural law as follows: "God as the external principle of good acts in two ways: he instructs us by His law and assists us by His grace. Law as one of the ways that God is a principle of action is the immediate context of Aquinas's treatment of natural law.") (citation omitted).

${ }^{43}$ William Edward Addis \& Thomas ARnold, A Catholic Dictionary 269 (1884) (stating that "Doctor Angelicus" is the "name given to St. Thomas of Aquin [sic]").

${ }^{44}$ Christopher DawsOn, Religion AND THE RISE OF WESTERN CULTURE 205 (1950) (mentioning the fundamental role of divine law since the times of European medieval political philosophy).

${ }^{45}$ See David Novak, Maimonides and Aquinas on Natural Law, in ST. ThOMAS AQUNAS \& THE NATURAL LAW TRADITION, supra note 39, at 43, 61 ("Therefore, there is some divine law that is perpetual because it is identical with either natural law or the supernatural reality of Christian revelation."). 
As Aquinas explained, natural law is the reflection of divine law in the human conscience. ${ }^{46}$ When properly discerned, natural law encompasses the features of divine law, to wit, its universal application, and trumps any other factors influencing the temporal realm. Two main consequences ensue from this premise: first, natural law embodies what is just, good, and desirable in every human society, and second, natural law may not vary according to time, location, or majoritarianism (the temporary expressions of the majority). ${ }^{47}$

The third level of the Aquinean legal pyramid is human law, the law of the polis (political community). ${ }^{48}$ It may be written on the books (positive law) or practiced by the community (customary law). Aquinas taught that human law is a derivative legal product. ${ }^{49}$ Therefore, to achieve legitimacy, it must be subordinated to natural law. To be valid and to serve as a foundation of the sovereignty claimed by those exercising auctoritas (authority), natural law must conform to divine law.

This pyramidal structure entails a hierarchy, where one level is subject to the other. Human law is subject to natural law, which shows what is good and just in society. Natural law is subject to divine law, which is the law of Revelation-the law that mandates not to murder, hurt, or lie to one's neighbor. ${ }^{50}$

This structure of legitimacy and organization has permeated the arrangement of legal systems in the Western world since the thirteenth century, based on outstanding intellectual efforts by the expositors of natural law. However, in the years prior to the Revolution, many ideologues advanced a coordinated philosophical discourse, used by the forthcoming political movement. In that vein, revolutionary ideologues presented a colossal, schematic, and systematic distortion-a suppressio veri (suppression of truth) — of the core certainties presented by the school of

\footnotetext{
46 See STANLIS, supra note 42 ("Divine law refers specifically to God's law as explicitly revealed to man.").

47 Steven A. Long, Natural Law or Autonomous Practical Reason: Problems for the New Natural Law Theory, in St. Thomas AQUINAS \& THE NATURAL LaW Tradition, supra note 39 , at 165,179 (referring to the "immutable divine" will-eternal law-that is the source of natural law).

${ }^{48}$ See StANLIS, supra note 42 (recalling that according to Aquinas the law is defined generally as "an ordinance of reason directed to the common good by those who have care of the community and promulgated").

${ }^{49}$ See id. (sustaining that "human law refers to what we understand as law in the ordinary sense and including custom") (emphasis added).

${ }^{50}$ See generally Natural Law and Sir William Blacktone, All ABOUT PHILOSOPHY, http:// www.allaboutphilosophy.org/natural-law-and-sir-william-blackstone-faq.htm (last visited Mar. 20, 2011) (discussing natural law).
} 
natural law, as Aquinas first presented. A quick review of these distortions is outlined below.

\section{A. Elimination of Divine Law from the Hierarchical Pyramid Presented by Thomas of Aquinas}

The French revolutionary ideologues kept the concept of natural law, but obliterated the belief of its foundation on divine, eternal law. ${ }^{51}$ They said that natural law was no longer based on divine law, but instead on human law - on human reason. ${ }^{52}$ Thus, the dogma of the social compact (political society) was born. ${ }^{53}$ The modern notion of democratic majoritarianism succeeded the ideology of the social compact, which founded its ontological support on the secular notion of natural law. Ultimately, the polis was no longer subject to any spiritual or divine power, but to itself, to the accord of the majority. ${ }^{54}$

The French Revolution moved away from the concept of natural law's validity in every location and time. In doing so, it embraced the idea of a natural law that depends on the mores of transitory and circumstantial majorities. Thus, natural law was divested of its claim to universality and uniformity. It became an idea nurtured in, and embraced by, relativism. This Article proposes that the combination of the secularized notion of natural law and the inordinate forces existing at the time of the Latin American independence triggered a malum praecessi (an evil result) - the legal, constitutional, and moral consequences of which are still present in the region.

\footnotetext{
51 Brigitte Basdevant-Gaudemet \& Jean Gaudemet, Introduction Historique au DRoIT XIIIE-XXE SIĖCLES 323 (2000) (referring to the new revolutionary concept of natural law as "indépendantes de Dieu") ("independent from God" (author's translation)).

${ }^{52} \mathrm{Id}$. at 322 ("Dans le domaine juridique, cela implique élaboration d'un droit nouveau, librement conçu par l'homme, dont le fondement soit la raison, qui soit au service du people et compris par lui.") ("In the legal field, this means developing a new law, freely designed by man, whose foundation is reason, that is at the service of the people, and is understood by him." (author's translation)).

53 See Richard John Neuhaus, The Naked Public Square: Religion and Democracy in AMERICA 38 (2d ed. 1984) (discussing the spiritual and religious underpinnings of the Revolutionary spirited agenda and commenting, "The 'scientific' approach of the secular Enlightenment is similar to the 'primitive' world views of ancient times. There is finally no real history, no real contingency, no real change; the world is either composed of static entities or what looks like change implies a cyclical recurrence of the same old thing. Judeo-Christian tradition, however, is premised upon the concept of real history, real change, and happening in an incomplete universe that is still awaiting its promised fulfillment.").

${ }^{54}$ Long, supra note 47, at 179 (referring to the "immutable divine" will-eternal law-as the source of natural law).
} 
The effect of a concept of natural law determined exclusively by the social compact implies that no further search into the metaphysical foundations of the law is necessary. According to the revolutionary democratic principle, it is the majorities who decide their own destiny, and the majorities also decide the content of natural law. ${ }^{55}$ In sum, the ultimate revolutionary idea concerning natural law is that once a society rids itself of the shackles of divine law, only positive law subsists as the source of all democratic legitimacy.

But even French revolutionary ideologues understood that leaving the majorities unrestrained would bring about dire consequences to their new society. Hence, they proposed the notion of public policy as a set of ethical principles that would act as a deterrent to positive law, counteracting the whims of the majorities. ${ }^{56}$ However, they could not avoid the fact that by debasing the Aquinean pyramid, they had to necessarily default to majoritarianism as a political rule. This view had to ultimately accept thatsince there is no longer an ultimate divine notion of what is right and wrong - it is up to majorities and, ultimately, the government, to determine restrictions on the exercise of power.

Another effect of the laicization of natural law is that any claims or attempts to detach the foundations of natural law from the will of the majority, whether permanent or temporary, are considered violations of the separation of religion and State. God's law, consequently, has no place in civil society. Man is sufficient to himself, and he should have emerged from the Enlightenment as the ultimate ruler of his own world.

\section{B. Natural Law Is No Longer Unchangeable, Universal, or Permanent}

Since the mores of the moment change, the new ideal of natural law is also open to change. According to this view, nothing wrong or inadequate should be perceived in this new arrangement of things. ${ }^{57}$ Human reason acts

55 Edmund Burke, Reflections on the Revolution in France 290 (The Temple Press Letchworth 1910) (affirming that "[t] he political dogma, which, upon the new French system is to unite the factions of different nations, is this, 'That the majority, told by the head, of the taxable people in every country, is the perpetual, natural, unceasing, indefeasible sovereign; that this majority is perfectly master of the form, as well as the administration, of the state.... that this is the only natural government; that all others are tyranny and usurpation" ").

56 INTRODUCTION TO COMPARATIVE LAW 95 (Konrad Zweigert \& Hans-Jürgen Kötz eds., 2d ed. 1987) (mentioning that "[f]reedom of contract is therefore the principle which dominates the law of obligations in the Code civil, restricted as little as possible by mandatory rules of law, called in France 'lois d'ordre public' [public policy laws]").

${ }^{57}$ See STANLIS, supra note 42, at 122 ("Neither 'abstract right' nor metaphysical 'truth' nor 'general will' nor 'utility,' nor anything else could replace or justify transgressions against the 
as the insuperably corrective element of undesirable constructions or applications of the new concept of natural law. If humans are reasonable beings, as the enlightened belief purports, there is nothing to fear from a rational exposition and molding of natural law. ${ }^{58}$

The revolutionary substitution of the will of the people for the millenary concept of divine law as the foundation of democratic legitimacy rested on the idea that majoritarian expressions of the people would act as a supreme check over irrational ideas and elements. However, this expectation has been tested against reality during the last two centuries. In fact, the last century alone saw millions and millions march to their deaths, forced by the will of "legal" regimes based on the majoritarian concept. ${ }^{59}$ As it stands today, the French revolutionary distortion of natural law is ontologically empty, morally bankrupt, and politically debased.

\section{Elitist, Moralistic, and Moralizing Ethos Tainted the Concept of Natural Law}

The proposition that a transitory majority can provide universal legal and moral legitimacy to the legal order at a given time was assured to rest on well-founded ground. However, truth and experience show that, without resorting to a foundational force, the soft, volatile, and compromising concepts of public policy ${ }^{60}$ and good morals advanced by the revolutionary codifiers as powers to overrule statutory law, will always be defined by the majority. ${ }^{61}$ A curious and empty moralist overtone replaced the prior religious foundations of natural law. The idea of moral restoration of society after the Revolution was coupled with the political elitism bred by the movement. In other words, the few enlightened men of the Revolution thought of themselves as the moral bastions of the political schemes that

ethical norms of the Natural Law.").

${ }_{58}$ See Tunc, supra note 17 , at 441 (noting the deification of reason by the French Revolution).

59 See, e.g., Alan Bullock, Hitler and Stalin: Parallel Lives (1993); see also RICHARD OVERY, THE DICTATORS: HITLER's GERMANY, AND STALIN's RUSSIA 192 (2004) ("In both regimes the security apparatus slowly accumulated legal instruments that allowed it to bypass the existing justice system... The Soviet system operated on an agreed legal foundation.").

${ }^{60}$ See James L. Dennis, Interpretation and Application of the Civil Code and the Evaluation of Judicial Precedent, 54 LA. L. REV. 1, 12 (1993) (referring to the daunting task of civil law judges when it comes to defining loose concepts, such as, "public policy").

${ }^{61}$ Heinrich A. Rommen, The Natural Law 141 (1979) ("In actual practice, the general will, because representative government is almost necessarily party government, is always best a majority decision against which the minority will ever claim the protection of the law."). 
developed. Recent history shows that many political experiments that clothed themselves in morality were a pretext for the repression and elimination of political dissidents. ${ }^{62}$

\section{The People Do Not Reserve Any Powers: All Are Transferred to the Majority As Represented by the Legislature}

The crooked notion of secular natural law preached by the Revolution entailed the legal principle that there is no longer a limit to the areas of life where the majority can govern. The foundation of this proposal lays in the concept that all the power and sovereignty are transferred from the majority of citizens to the legislature. ${ }^{63}$ However, this total-transfer of sovereignty within the revolutionary Constitution of $1791^{64}$ runs counter to the contemporary notion of democracy, and has fueled many important debates, for example, in the United States since its inception. ${ }^{65}$

Every political revolution needs an ideology ${ }^{66}$ The bourgeois Revolution was not an exception and, accordingly, chose nationalism as the cornerstone of its philosophy. ${ }^{67}$ Sovereignty, therefore, became the legal expression of nationalism ${ }^{68}$ - both internally with respect to its subjects, and externally

${ }^{62}$ Conan Fischer, Europe Between Democracy and Dictatorship: 1900-1945, in IV BLACKWELL HISTORY OF EUROPE 284 (2010) ("Hitler's protestations of peace needed to be taken seriously, but only alongside 'a moral renewal and the rapid and rigorous perfecting of [France's] military forces.' ").

${ }_{63}$ See John H. Merryman, On the Convergence (and Divergence) of the Civil Law and the Common Law, 17 STAN. J. INT'L L. 357, 359 (1981) ("Many view the rise of the nation-state and the emphasis on state sovereignty as an exaggeration, as one of those periods of history in which the pendulum has swung too far ....").

${ }^{64} 1791$ CONST, tit. III, para. 2 (Fr.) (affirming that sovereign powers may be exercised by the nation, "from which alone all powers emanate ... only by delegation").

${ }^{65}$ See generally Martin A. Rogoff, A Comparison of Constitutionalism in France and the United States, 49 ME. L. REV. 21, 58 (1997) (discussing Carré de Malberg's rejection of the "Rousseauian equation of la souveraineté nationale [national sovereignty] with direct democracy," as an example contrasting the differences between the American and French notions of representative democracy).

${ }_{66}$ ANTONIO Rosmini, 39 Filosofia DEL Diritto 1401 (1967) ("Il movimento del 1789 fu movimento d'irritazione . . . le idee dovevano dunque essere e furono orribilmente confuse.") ("The movement of 1789 was the movement of irritation . . . the ideas had to be and were so horribly confused." (author's translation)).

${ }^{67}$ See Louis Henkin, Revolutions and Constitutions, 49 LA. L. REv. 1023, 1030 (1989) ("In a radical sweep, the [French] Revolution replaced sovereignty in the king with sovereignty in the Nation.").

${ }^{68}$ See Julie Chi-hye Suk, Equal by Comparison: Unsettling Assumptions of Antidiscrimination Law, 55 AM. J. CoMP. L. 295, 300 (2007) ("The French Revolution also enshrined a republican conception of sovereignty which has endured in the constitution presently in force. The Declaration stated, 'The principle of all sovereignty resides essentially in the nation. No body nor individual may exercise any authority which does not proceed 
with reference to other states. ${ }^{69}$ It is precisely here where the explanation of the expansion of colonial powers in the epoch after the Revolution finds its foundations. $^{70}$

\section{A TOTAL AND Rigid SEPARATION OF RELIGION AND STATE}

Nowhere was the Revolution more blatant than in its attempts at obliterating the Catholic religion. ${ }^{71}$ To achieve this goal, the revolutionary ideologues advanced the red herring concept of "separation" between religion and State. ${ }^{72}$ This "wall" of separation brought about some specific consequences, some of which are presented below.

\section{A. Religion Has No Role in the Public Square}

Montesquieu, the high priest of the Revolutionary philosophical advance, stated it clearly: "Thus, venerable as those ideas are which immediately spring from religion, they ought not always to serve as a first principle to the civil laws; because these have another, the general welfare of society."73

From "not always" "7 to "not ever" there is a simple, short walk. The denial of religion's role in the public square subsequently led to its seclusion in the private realm. As an expression of the majority, the belief that government action prevails over religion denies religion's role once a government renders religion's exercise a "concession" or an act of government tolerance. In that sense, religion-the utmost expression of human reason and faith in search of the infinite and consequential moral codes that emerge therefrom ${ }^{75}$-is deprived of its core element of religare

directly from the nation.' ").

69 See generally John Henry Merryman \& Rogelio Pérez-Perdomo, The Civil Law TRADITION: AN INTRODUCTION TO THE LEGAL SYSTEMS OF EUROPE AND LATIN AMERICA 20 (3d ed. 2007) (referring to the concept of "internal sovereignty" advanced by the French Jean Bodin and the English Thomas Hobbes, and to that of external sovereignty proposed by Hugh Grotius, which "looked more to the relation among states").

${ }_{70} I d$.

${ }^{71}$ See infra note 191 .

72 See Jennifer M. Westerfield, Behind the Veil: An American Legal Perspective on the European Headscarf Debate, 54 AM. J. CoMP. L. 637, 646-47 (2006) ("The history of secularism begins with the rise of the French idea of laïcité, which in turn finds its roots in the anticlericalism that developed during the French Revolution....'[I]t is a political notion involving the separation of civil and religious society, the State exercising no religious power and the churches exercising no political power." "(citations omitted)).

731 CHARLES DE SECONDAT, THE SPIRIT OF LAWS 65 (1748).

${ }^{74} \mathrm{Id}$.

${ }^{75}$ See, e.g., Jeffrey Omar Usman, Defining Religion: The Struggle to Define Religion Under the First Amendment and the Contributions and Insights of Other Disciplines of Study 
(binding the community together). ${ }^{76}$ Instead, the revolutionary attitude toward religion was to relegate it to a subordinate role. Finally, the French Revolution was lofty to affirm that Caesar had prevailed over God. ${ }^{77}$

The public role of religion in the West was for millennia, accepted as a necessary force for good in society. ${ }^{78}$ Tension between religion and State existed, and much has been written about it. However, the discussion has focused more on the jurisdictions of each field; texts have examined the spiritual versus the temporal, ${ }^{79}$ rather than the participation of religion in the shaping of temporal societies. History depicts religion building Western European legal culture. $^{80}$ In denying the role of religion, the French Revolution attempted to demolish the European legal culture.

Including Theology, Psychology, Sociology, the Arts, and Anthropology, 83 N.D. L. REv. 123, 201 (2007) (describing "humanity's attempt to create a constrained and conditioned finite understanding of the infinite").

${ }^{76}$ C. John Sommerville, Defining Religion and the Present Supreme Court, 6 U. FLA. J.L. \& PuB. POL'Y 167, 172 (1994) ("'[R]eligion' comes from the Latin religare, which means to hold back or bind fast.").

77 RoMmEN, supra note 61, at 89 (alluding to "Locke substitutes for the traditional idea of natural law ... as a moral reflex of the metaphysical order of the universe revealed to human reason in the creation of God's will, the conception of natural law as a rather nominalistic symbol for a catalogue or bundle of individual rights that stem from individual self-interest").

${ }_{78}$ See, e.g., Paul B. Rasor, Biblical Roots of Modern Consumer Credit Law, 10 J.L. \& RELIGION 157, 192 (1993) ("As religion became intertwined through narrative with moral norms and social concerns, it became more than cult and ritual... . Both religion and law became blended into covenant, which formed the guiding moral and ethical principles of the society. These principles have become so deeply ingrained that they have permanently affected the way we think about law.").

${ }^{79}$ See, e.g., Steven D. Smith, Is A Coherent Theory of Religious Freedom Possible?, 15 CONST. COMMENT. 73, 74 (1998) ("The enduring problem is to determine how these matters stand in relation to each other. Does the spiritual take priority over the temporal, or vice versa? Is the spiritual more real, or more authoritative, than the temporal ...?"); see also Ira C. Lupu, The Distinctive Place of Religious Entities in Our Constitutional Order, 47 VILL. L. REV. 37, 84 (2002) ("Seen in political terms, 'religion' represents that which the new order disclaims: jurisdiction over ultimate truths, a comprehensive claim to undivided loyalty, and a command to worship. Separationism, then, depends on articulation of this political concept of sacredness and on some attempt to identify what particular aspects of the behavior of religious institutions are bound up with the sacred.").

${ }^{80}$ DAwson, supra note 44 , at 14 (stressing that during the later centuries of the Middle Ages, "everywhere we see the co-operation of men and movements of diverse national origins which tended towards the creation of a common but highly variegated pattern of culture throughout Western Christendom"); see also HILAIRE BELlOC, THE CRISIS OF CIVILIZATION 1 (1937) (offering that "the culture and civilization of Christendom-what was called for centuries in general terms 'Europe,' was made by the Catholic Church gathering up the social traditions of the Grœco-Roman Empire, inspiring them and giving the whole of that great body a new life"). 


\section{B. Social Justice Is a Secular Concept to Which Religious Views Are Alien}

The secularization of law brought together other "collateral" damage as well. For example, the idea of "social justice" became an entirely secular concept devoid of religion. ${ }^{81}$ The Revolution affirmed the duty of the State (as representative of the majorities) to determine what is aequo et bono (equitable and good) in society. Because the will and priorities of a State change depending on place and circumstance, the relativization of goodness, beauty, and justice implies a flat denial of any universal truths - that is, those applicable to all men, at all times, and in all places and circumstances. ${ }^{82}$

As a result, truth becomes a relative concept that is dependent on the hearts or minds of members of a society at a given time. In this view, the majority of a society defines the nature, content, and consequences of social justice. Members of a collective are not impeded from professing a definition of social justice grounded on religious belief, as long as their perspectives do not conflict with the majority. In a nutshell, the French Revolution's message concerning the role of religion in public life is: if you have religious ideas, you may hold them, but do not bring them into society. Ultimately, religion created the culture that the revolutionaries attempted to undermine and destroy.

During the twentieth century alone, majorities, whether real or artificial, have in many cases either actively promoted or tolerated the worst genocides humanity has ever witnessed. An author masterfully stated: "majority rule is no sure guarantee of freedom." ${ }^{\prime 83}$ In other words, the majority does need a system of checks and balances. The authentic concept of natural, universal law provides this system, which was denied by the French Revolution.

${ }^{81}$ ROMMEN, supra note 61, at 107 (mentioning that "[t]he individualist natural law of rationalism . . . owed [its] significance to its ethical and politico-economic aims, which were raised to the sublime dignity of natural justice").

${ }^{82}$ See Pope Benedict XVI, EnCYClical LeTter Caritas In Veritate $\$ 59$ (2009), available

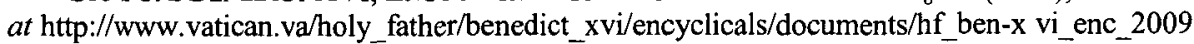
0629_caritas-in-veritate_en.html ("In all cultures there are examples of ethical convergence, some isolated, some interrelated, as an expression of the one human nature, willed by the Creator; the tradition of ethical wisdom knows this as the natural law. This universal moral law provides a sound basis for all cultural, religious and political dialogue, and it ensures that the multi-faceted pluralism of cultural diversity does not detach itself from the common quest for truth, goodness and God." (citations omitted)).

${ }^{83}$ NeuHaus, supra note 53 , at 30 (also stating that "in the century of Hitler, Stalin, and Mao, however, it is hard to understand how anyone could think the threat of totalitarianism to be bogus"). 


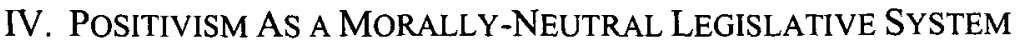

In the revolutionary juridical paradigm, the law becomes the highest and supreme norm ${ }^{84}$ - the voice of the status quo. Positive law only recognizes limitations imposed by a secular notion of natural law as its external boundaries. As the new revolutionary paradigm denied the immutability of natural law, as it had been explained by the traditional scholastic doctrine more than a millennia before, the logical consequence was that natural law came to be conceived as a changing element according to time and location. The logical effect of this misconception is that in the absence of a subordination of positive law to natural law, the former was understood as owing no allegiance to any higher value other than itself. ${ }^{85}$ In other words, if alleged democratic majorities determine the substance of both positive law and natural law, they also divide or unite the pathways between them. In this context, it could be said that the unrestricted confidence that the French revolutionaries placed in the supremacy of positive, written law, for the first time in history, put into actual practice the notions of legal positivism. ${ }^{86}$

The Revolution's adoption of positivism resulted in a series of legal consequences, some of which are analyzed below.

\section{A. No Role for Stare Decisis}

Revolutionary sectarianism meant that some attempted to eliminate jurisprudence as a source of law altogether ${ }^{87}$ Fortunately, the revolutionaries did not take this step. Since, in the revolutionary creed, natural law no longer derived its foundations from divine law, only positive law could establish what is good and fair in society. ${ }^{88}$ The foremost

\footnotetext{
${ }^{84}$ BASDEVANT-GAudemET \& GAUdEMET, supra note 51, at 393 ("La loi demeure la norme supérieure.") ("The law remains the highest norm." (author's translation)); id. at 425 ("Depuis la Révolution, la loi est toujours considérée comme la source supérieure en droit interne.") ("Since the Revolution, the law is still considered the highest source of law in domestic law." (author's translation)).

${ }^{85}$ VAN CAENEGEM, supra note 21, at 118 (stating that the School of Natural Law bred by the French Revolution "conceived natural law as a body of basic principles from which positive law ought to be directly derived: it was an applied natural law [and it] refused to derive its principles from external systems such as divine law or the corpus iuris").

${ }^{86}$ BASDEVANT-GAUDEMET \& GAUDEMET, supra note 51, at 330 (mentioning the "triomphe du légalisme") ("triumph of legalism" (author's translation)).

${ }^{87}$ Id. at 425 ("On sait que Robespierre aurait voulu éliminer la jurisprudence .....") ("It is said that Robespierre wanted to eliminate jurisprudence ...." (author's translation)).

${ }_{88}$ RoMmen, supra note 61 , at 118 (referring to the ideas expounded by F.J. Stahl, philosopher of the historical school (1802-1861), for whom "the highest principles touching the binding force of the positive law-that one must obey the public authorities; whether there
} 
consequence results in no stare decisis ${ }^{89}$ - that is, no "allegiance" to previous positive law or existing case law. This attitude prompted the demise of stare decisis in civil law. ${ }^{90}$

Since, in every case, the adjudicatory procedure must start from scratch without referencing past decisions, stare decisis became obsolete in Latin America, France, and elsewhere. ${ }^{91}$ Laws dictated what was good, without referencing any prior judicial decision. Stare decisis, on the other hand, involves a certain amount of certainty and predictability-that like cases should be treated alike, and that "justice should not only be done but should appear to have been done."92 Nevertheless, the French Revolution rejected both the substantive merit and the appearance of justice conceived under stare decisis.

Adjudication became an activity performed ex tabula rasa (absent of preconceived ideas). This approach came from the profound contempt French revolutionaries held toward canon law (the law of the Church) and customary law (thought to be the law of the barbarians). ${ }^{93}$

A recent comparative study by a Swiss scholar effectively illustrates the lasting effect of the revolutionary abolition of stare decisis. ${ }^{94}$ This study demonstrated the considerable difficulty civil law systems have experienced in developing theories and techniques for handling case law. ${ }^{95}$ Civil law jurisdictions have faced hardships when trying to change the revolutionary paradigm, which denied prior judicial decisions any precedential value. Prior decisions were deemed to lack any utility or authority to shape the mainstay of current laws. ${ }^{96}$ Statutory law became the voice of the status quo,

is a limit to this obedience, and what the limit is; whether active resistance is permissible-lie beyond positive law. Yet this pertains not to natural law, but to ethics.").

${ }^{89}$ Dennis, supra note 60 , at 3 ("The Civil Code is the primary source of law, and precedent serves merely as an example of a judge's interpretation and application of legislated law.").

90 VAN CAENEGEM, supra note 21 , at 130 ("Robespierre would actually have been happy to see the term 'case law' disappear from the French language, since 'in a state having a constitution and legislation, the case law of courts is nothing other than statute." ").

91 Bernard Schwartz, The COde Napoleon and THE COMMON-LAw World: The SesquicentenNial Lectures Delivered at the LAw Center of NeW York UNiversity, DECEMBER 13-15, 1954, at 397 (1998) (quoting Professor Lambert of the University of Lyons as saying, "In France, the judicial precedent does not, ipso facto, bind either the tribunals which established it not the lower courts.").

92 John HenRy MERryman et al., The Civil Law Tradition: Europe, Latin America, AND EAST ASIA 208 (1994).

93 VAN CAENEGEM, supra note 21 , at 125 ("The nationalization of law was at the expense both of the cosmopolitan ius commune and of particular local customs.").

94 Thomas Probst, Die ANDERUNG DER REChtSPREChung (1993), cited in MerRyMAN ET AL., supra note 92 , at 209.

95 Id.

96 SCHWARTZ, supra note 91, at 66 (recalling that "the practical effect of stare decisis is that 
and it grew to despise any past precedents. This way positive law achieved supremacy at any given time in societal life.

After World War II, France instituted a Constitutional Council, whose decisions were designed to be final and hold precedential value. ${ }^{97}$ European and Latin American countries also created their own constitutional courts in the last decades, ${ }^{98}$ and empowered the constitutional chambers or their highest courts (usually the Supreme Court) with the power to issue precedential decisions affecting statutory law deemed to be contrary to the constitution." However, these innovations-referred to as the "French Deviation" $" 100$ are but a digression from an original deviation.

\section{B. The Truncated Role of Custom}

A profound contempt for canon law and customary law ${ }^{101}$ was at the root of the legal principles that shaped the Revolution. ${ }^{102}$ Accordingly, as the

of vesting courts with the power to determine in a general manner, and to implement by regulations, as the Code Napoleon states, the contents of statutory provisions").

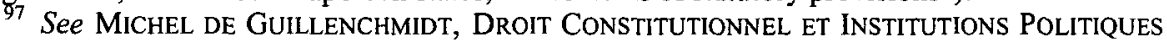
382-85 (2005) (highlighting the lack of constitutional control mechanisms before the Constitution of 1958, the proposals that existed dating back to 1795 to create a "constitutional jury" to that effect, and the creation of the constitutional court was a "considerable novelty" in the French constitutional system); see also Alec StONe, THe BIRTH OF Judicial Politics IN France: The Constitutional Council IN Comparative Perspective (1992); id. at 8 ("[E]ach Council decision necessarily constitutes the final, substantive stage of the policymaking process."); $i d$. at 116 ("[T]he Council is indeed a kind of high juridiction.").

${ }_{98}$ Carl Baudenbacher, Some Remarks on the Method of Civil Law, 34 TEX. INT'L L.J. 333, 355 (1999) ("After World War II, most Continental European countries established constitutional courts with characteristics of common law courts.").

99 See Mauricio Garcia-Villegas, Law as Hope: Constitutions, Courts, and Social Change in Latin America, 16 FLA. J. INT'L L. 133, 137-39 (attributing principles of maximalist judicial activism and militant constitutionalism to the "aspirational" Colombian constitution); id. at 150 (describing the factors of instability and inflexibility that led to the 1990 Constitutional Assembly); David Landau, The Two Discourses in Colombian Constitutional Jurisprudence: A New Approach to Modeling Judicial Behavior in Latin America, 37 GEO. WASH. INT'L L. REV. 687, 726 (2005) (describing the philosophy of the Colombian constitutional court as including "creative judicial work"); Miguel Schor, An Essay on the Emergence of Constitutional Courts: The Cases of Mexico and Colombia, 16 IND. J. Global LEGAL STud. 173, 187-88 (2009) (describing how the 1991 Colombian Constitution permits a constitutional court to review constitutional complaints filed by individuals). But see Manuel González Oropeza, Recent Problems and Developments on the Rule of Law in Mexico, 40 TEX. INT'L L.J. 577, 583 (2005) (noting that the Mexican judiciary has no plenary powers and can only suspend a law's effectiveness between parties but not abrogate it).

${ }^{100}$ Felipe Sáez Garcia, The Nature of Judicial Reform in Latin America and Some Strategic Considerations, 13 AM. U. INT'L L. REV. 1267, 1283 (1998).

${ }_{101}$ Charles Sumner Lobingier, Napoleon and His Code, 32 HARV. L. Rev. 114, 116 (1918) (pointing out that the Convention of 1791 looked upon customary law as a "barbarian and degenerate" system). 
State became the unique source of law, enjoying a sacred, law-making monopoly, custom could no longer be a source of law. ${ }^{103}$ Thus, custom was submerged as a subordinate, secondary source of law based on the predicament that one, uniform law-applicable to everyone in the polismust govern the people. The new understanding of customary law, in due course, abolished the free expressions of the people. ${ }^{104}$ Prior to the Revolution, there was a lively interaction between the European ius commune and customary law. ${ }^{105}$ The latter was rather disorganized and highly local - a chaotic state that the revolutionaries swore to abolish. ${ }^{106}$

The phenomenon - a lack of uniformity-was not going to pass the revolutionary test. Legal homogeny became a goal in and of itself. If some sort of evenness previously existed under the European ius commune, ${ }^{107}$ the Revolution deemed it soft on, and tolerant of, local customs. The Revolution's attitude toward local customary law established prior to 1789 is reflected by Voltaire's observation, "[W]ith the improvements in communications, it became absurd to pass from the domain of one law to that of another every time it was necessary to change horses." 108 Thus, legal uniformity became one of the primary objectives of the revolutionary experiment- to be established fully and irrevocably by the power of the State. However, customary law, which derived from the free expression of

102 VAN CAENEGEM, supra note 21, at 117 (referring to the French Revolution idea that "old customs and books of authority must be replaced by law freely conceived by modern man, and whose sole directing principle was reason").

${ }^{103}$ BASDEVANT-GAUDEMET \& GaUdemET, supra note 51 , at 430 ("Le Code Civil a expressément abrogé l'ancien droit coutumier, dans toutes les matières désormais régies par la loi. Le droit coutumier a définitivement perdu la place qu'il occupait auparavant.") ("The Civil Code has expressly repealed the old customary law, in all of the matters theretofore governed by the law. Customary law has definitively lost the place it had up to that time." (author's translation)).

104 See adolphe Granier de Cassagnac, Histoire des Causes de la RÉvolution FRANÇAISE 189 (Auguste Pagny ed., 1850) (reviewing the protections provided by the old customary law to families and their patrimonial properties).

${ }_{105}$ David J. Ibbetson, COMMON LAW AND IUS COMMUNE 6 (2001) ("[T]he ius commune constituted what has been described by one recent writer as 'a secure point of reference'; it was the background to the operation of local statutes and customs.").

106 See Thomas Glyn Watkin, An Historical InTRoduction to Modern Civil Law 100 02 (1999) ("[C]ivil law had won one victory; French law had surrendered to the advantages of having its laws enshrined in written texts, and this would let in that other feature of civilian learning, the opportunity for reasoned, juristic development of legal doctrine.").

107 BASDEVANT-GAUDEMET \& GAUDEMET, supra note 51, at 408 ("[L]e droit romain es un droit mondial, applicable à toutes les nations.") ("And Roman law is a worldwide law, applicable to all nations." (author's translation)).

${ }^{108}$ Alain Levasseur, Code Napoleon or Code Portalis?, 43 TuL. L. REv. 762, 763 (1968). 
the people, has been "routinely dismissed as of slight practical importance" since the revolutionary days. ${ }^{109}$

Then, customary law retained a supplementary, subordinate role as a source of law that could never abrogate the written law. ${ }^{110}$ The only exception to the downgraded role of customary law in civil law countries applied to the field of commercial law. ${ }^{111}$ The reason for this exception can be attributed to commercial law as lex mercatoria (the law of the merchants) - the law of the business class, the bourgeoisie, and those who provided the heart, soul, hands, and guillotine to the Revolution. The uses, habits, and practices constituting lex mercatoria were kept as a crucial element for the furthering of their businesses. ${ }^{112}$ For custom to maintain a role in revolutionary-inspired commercial law, a good exception had to be found. The use of disenfranchised people, nonetheless, did not result in a better place in the revolutionary pyramid of legal sources. Customary law was circumscribed to a demoted, supplementary role on the scale of legal authorities.

Even in situations where commercial custom is afforded a role in civil law jurisdictions, it is subject to meaningful restraints. Custom is recognized exclusively secundum legem (according to law) ${ }^{113}$-when it accords to

\footnotetext{
109 MERRYMAN ET AL., supra note 92, at 203.

${ }^{110}$ Id. at 203-04.

111 Id. at 204 (stating that "[c]ustom, in the form of trade usage, plays a greater role in commercial ... law than it does in civil law generally"); see also CÓDIGO DE COMERCIO (COMMERcial CODE) [CóD. Com.] art. 4 (Chile) (providing that "commercial custom [can] substitute for the silence of the law, when the facts forming the custom are uniform, public, generally executed in the Republic or in a specific locality, and reiterated for a long period of time" (author's translation)).

112 Felix Dasser, Lex Mercatoria - Critical Comments on a Tricky Topic, JUSLETTER, Jan. 2003, at 5, available at http://www.homburger.ch/fileadmin/publications/LMCRIT.pdf ("This regime [France's] which was held to embrace the revolutionary Lex Mercatoria doctrine .....").

113 Código Civil (Civil CODE) [CóD. Civ.] art. 2 (Chile) ("Custom is not law except in the cases where the law refers to it."), copied verbatim in Articles 2 of the Civil Codes of Ecuador, El Salvador, and Honduras; see also Código Civil [CóD. Civ.] [CIvil CoDE] art. 17 (Arg.) ("Uses and customs may not create rights, except when the laws refer to them, or in situations that are not covered by the law." (author's translation)). Código CiviL [CóD. CIV.] [CIVIL CODE] art. 8 (Colom.) ("In no case may custom have a force contrary to law. Desuetude or lack of practice, even if immemorial and general, may not be sustained as a reason not to comply with the law." (author's translation)); Código CIVIL [CóD. CIV.] [CIVIL CODE] art. 3 (Costa Rica) ("Uses and custom may only apply in the lack of applicable law, provided that their existence has been proven and they are not contrary to the morals or the public order, or to a prohibitive law." (author's translation)); Cóbigo CIVIL FeDERAL [CC] [FEDERAL CIVIL CODE] art. 10 (Mex.) ("No desuetude, custom or practice contrary to a law may be argued as an excuse for noncompliance with a law." (author's translation)); CóDigo CIVIL [CIVIL CODE] art. 7 (Para.) ("The use, custom or practice may not create rights, except when the laws refer to them." (author's translation)); CóDIGO CIVIL DE LA R.O. DEL URUGUAY
} 
positive, statutory law. ${ }^{114}$ In sum, with scant exceptions, after 1789 customary law bid farewell to the pyramid of legal sources in the civil law world.

\section{General Principles of Law}

The general principles of law in post-revolutionary France awaited a similar fate as customary law. Society dictated that the general principles of law had no place in the legal system unless and until positive law expressly accepted it. ${ }^{11}$

Civil law scholars tediously explain the role of general principles of law in civil law systems, oftentimes without much success. At their core, the general principles of law have no persuasive power unless referred to by primary sources of law. However, reality shows that "[E]ntire bodies of law in civil law systems have been built up by judicial decisions in a manner closely resembling the growth of anglo-American common law."116 Thus, people assume that general principles of law create the foundation for case law.

One example contrary to this trend is the principes généraux du droit administrative (general principles of administrative law) developed by the French Council of State ${ }^{17}$ These principles provide an exception to the lack of persuasiveness of the general principles of law, because the Council created new legal institutions without resorting to any primary source of law, namely, statutory law. ${ }^{118}$ Another instance is the creation of certain administrative tort law liability theories, such as the doctrine of the abuse of rights and the doctrine of administrative imprévision (unforeseeability). ${ }^{119}$

[CIVIL CODE] art. 9 ("Laws may only be repealed by other laws; neither desuetude, custom or practice contrary to the laws may be argued as an excuse for noncompliance with the laws." (author's translation)); Código CIVIL [CIVIL CODE] art. 7 (Venez.) ("Laws may not be repealed but by other laws; neither desuetude, custom or practice contrary to the laws, no matter how old or universal, may be argued as an excuse for noncompliance with the laws." (author's translation)).

${ }_{114}$ The Constitution of 1791 abolished the old custom of the right of aubaine; that is, the right of the Crown to acquire ownership over the property of foreigners to the exclusion of testate or intestate heirs. CONST. tit. VI (Fr.) ("Foreigners, established in France or not, may inherit from their French or foreign kinsmen.").

115 MerRyman eT AL., supra note 92, at 204.

116 Id. at 208.

117 Rogoff, supra note 65, at 76 ("Moreover, in interpreting and judging the legality of executive legislation and specific administrative actions, the Conseil d'État applies principes généraux du droit (general principles of law).").

${ }_{118}$ Id. ("These principles are deduced as a matter of statutory interpretation.").

119 Merryman ET AL., supra note 92, at 209. 
On the other hand, Germany, a dubiously pure civil law country, still accepts " 'certain general principles which the legislators have not rendered in the form of positive rules.' ",120

Notwithstanding these examples, the general principles of law from recent case law in France, at least, illustrate the same concept of natural law exhibited prior to the French Revolution. ${ }^{121}$ As a result, the case law only partially resurrects the heritage of the pre-Revolution legal tradition. ${ }^{122}$ Instances of these principles include the theories of fraus omnia corrumpit (fraud corrupts everything), nemo contra factuam proprium venire potest (doctrine of unclean hands), and enrichessement san cause (unjust enrichment). ${ }^{123}$ The revolutionaries looked at the traditional general principles of law with suspicion, as another manifestation of the legal order they sought to abolish. As a result of the slow return of these theories via the general principles of law prior to the Revolution, revolutionary civil law fully subordinated these principles to statutory law. ${ }^{124}$ For example, although the Spanish Civil Code of 1889 includes the general principles of law as a legal source in Spain, the general principles are clearly subordinate to statutory law and customary law. ${ }^{125}$ Generally, Latin American civil codes follow the same approach as the French and the Spanish, securing the general principles as a subsidiary source of law. ${ }^{126}$

\footnotetext{
${ }^{120} I d$. at 206.

121 See STANLIS, supra note 42 , at 80 ("To Burke the Natural Law was so basic to the ancient social order of Europe that its subversion was enough proof that the [French] revolution was the most extensive project ever launched against all religion, law, property, and real civil order and liberty.").

${ }^{122}$ Bernard Schwartz, French Administrative Law and the Common-Law World 270 (2006) ("It is only because the classical notion of sovereignty, accepted without question by the men of the Revolution, has been coming to be repudiated by French legal theory that the principle of State liability has been able to extend itself over the entire field of public law.").

${ }^{123}$ See generally John Bell et AL., Principles of French LaW 433-40 (2d ed., 2008) (analyzing the civil equitable remedy of unjust enrichment); id. at 417-33 (reviewing other jurisprudential equitable remedies in French Law, namely, the gestion d'affaires (unrequested management of another person's affairs); and the repetition de l'Indu (recovery of "undue payments')).

${ }_{124}$ See generally JEAN-MARC MaIllot, LA THÉORIE ADMINISTRATIVISTE DES PRINCIPES GÉNÉRAUX DU DROIT 69 (2003) (highlighting the "valeur infralégislative" [infra-legislative hierarchy] of the general principles of law).

${ }_{125}$ CóDIGo CIVIL [CÓD. CIV.] [CIVIL CODE] art. 1 (Spain), available at http://www.ucm.es/in fo/civil/jgstorch/leyes/ccivil.htm ("Los principios generales del derecho se aplicarán en defecto de ley o costumbre, sin perjuicio de su carácter informador del ordenamiento jurídico.") ("The general principles of law shall be applied in defect of the law or custom, without prejudice of their role in informing the legal system." (author's translation)).

${ }_{126}$ See, e.g., Código CIVIL [CóD. CIV.] [CIVIL CODE] art. 16 (Arg.) (establishing that is conflict may not be decided by resorting to the letter or the spirit of the law, the principles of
} 


\section{Role of Equity}

It has been stated, throughout the centuries, almost ad nauseam, that whereas equity is a source of law in common law systems, ${ }^{127}$ it is denied that same authority in civil law jurisdictions. ${ }^{128}$ As explained elsewhere in this Article, positivism denies the existence of primary sources of law other than written statutes. ${ }^{129}$ Philosophically, at least, the judicial function needs equity as the remedial tool par excellence. The new revolutionary regimen was to inflict an unprecedented capitis diminutio (decrease of head) coup to the judicial function in the West. ${ }^{130}$ To achieve this objective, revolutionaries denied judges equitable powers in post-revolutionary times. ${ }^{131}$ Equitable powers were deemed incompatible with the new role of judges and their duties. ${ }^{132}$

analogous statutes may be used; and that if the doubt persists, the general principles of law must be used); Código Civil [Cón. CIv.] [CIVIL CODE] art. 1 (Costa Rica) (stating that, together with custom and uses, the general principles of law are unwritten sources of private law, used to interpret, delimitate, and integrate the written sources of law); CóDIGo CiviL FEDERAL [CC] [FEDERAL CIVIL CODE] art. 19 (Mex.) (establishing that civil controversies must be decided in accordance with the letter or the legal interpretation of the law, and in the lack thereof, in accordance with the general principles of law); Código CIVIL [CIVIL CODE] art. 6 (Para.) (providing language analogous to Article 17 of the Nicaraguan Civil Code); Cóbigo Civil [CIVIL CODE] art. 8 (Peru) (providing that judges may not excuse themselves from dispensing justice based on a legal lagoon, or a defective law. In these cases, the judges must apply the general principles of law; preferably, those inspiring the Peruvian legal order); Código CIVIL DE LA R.O. DEL URUGUAY [CIVIL CODE] art. 16 (providing language analogous to Article 17 of the Nicaraguan Civil Code, and Article 6 of the Paraguayan Civil Code, respectively); CóDigo CIVIL [Civil CODE] art. 4 (Venez.) (mandating that, when there is no specific law applicable to a case, legal provisions regulating similar cases or analogous matters are to be taken into consideration and, in case of doubt, the general principles of law shall apply). The Chilean Code of Civil Procedure, Article 170, provides that final decisions must show the laws on which the case is decided, and if no laws exist, the equity principles used by the judge to decide the case.

${ }^{127}$ For a review of the basic differences between the core institutions of civil and common law, see F.H. LAWSON, A COMMON LAWYER LOOKS AT THE CIVIL LAW (1953); see also Gino Gorla, Samuel Livermore (1786-1833): An American Forerunner to the Modern "Civil LawCommon Law Dialogue," in COMPARATIVE and PRIVATE INTERNational LaW: EsSays IN HONOR OF JOHN HENRY MERRYMAN ON HIS SEVENTIETH BIRTHDAY 121-37 (David S. Clark ed., 1990).

${ }_{128}$ See John Henry Merryman, On the Convergence (and Divergence) of the Civil Law and the Common Law, 17 STAN. J. INT'L L. 357, 381 (1981) (addressing the "quite different prevailing views of the role of judges in the Civil Law and Common Law," with a specific reference to equity).

${ }^{129}$ See supra note 86 and accompanying text.

130 SCHWARTZ, supra note 122, at 14 ("The judicial function is a more limited one.").

131 A Decree of March 5, 1803, Sec. 5 provided that "[ $[$ ] pronounce, by way of general and legislative determination, on the causes submitted to them."

${ }^{132}$ Levasseur, supra note 108, at 771 (criticizing the strictures of the approach to the role of 
The legislature provided legal solutions to situations which the judicial use of equity previously resolved. ${ }^{133}$ With legislative, statutory solutions to all the legal problems arising in the polis, judicial creativity, or eccentricity, had no role to fulfill. ${ }^{134}$

However, to the Revolution's chagrin, statutory law could not provide for all situations or major issues that needed to be resolved. ${ }^{135}$ The only egress from this dilemma was to allow judges to use equity, but with a decisive modifier: exclusively when no statutory solution for a given case existed. ${ }^{136}$ This solution posed questions, such as, what alternatives did the revolutionary legal minds have for this situation? Was it possible to ask the legislature to legislate vis-à-vis every new situation that required a legal solution? Would that approach transform the essence of the legislative function into one proper of the judicial branch? Ultimately, this alternative was not viable based on the Montesquieuan principle of separation of powers, ${ }^{137}$ as honored by the Revolution. Another solution had to be found.

Thus, the revolutionaries determined that the judiciary could, in rare cases, create law using equitable powers and offer a legal solution where none had been provided. However, judicial equitable powers were substantially restricted and limited to the "non-provided for cases," and were established in default of written law. ${ }^{138}$

This revolutionary concept of equity was codified in Andrés Bello's Civil Code, ${ }^{139}$ which is the source of most Latin American civil codes. Equity

equity in the French legal system, and arguing that what is desirable is that "if there is no particular enactment [in a given case], custom or equity must be consulted").

${ }^{133}$ Eva Steiner, French LaW: A Comparative Approach 71 (2010) ("Equity in France has never been considered a proper source of law.").

${ }^{134} \mathrm{Id}$. at 66 (outlining the "French approach to statutory interpretation," which greatly limits the interpretive role of judges).

${ }_{135}$ SCHWARTz, supra note 122, at 157 (comparing the different perspectives of the French American systems in situations where the legislature had been silent).

${ }_{136}$ See, e.g., Código be Procedimiento Civil [Cod. Proc. Civ.] art. 170 (Chile).

137 Charles de Secondat, supra note 73, at VI ("Montesquieu held that governmental powers should be separated and balanced to guarantee individual rights and freedom.").

${ }_{138}$ Maria Luisa Murillo, The Evolution of Codification in the Civil Law Legal Systems: Towards Decodification and Recodification, 11 FLA. ST. J. TRANSNAT'L L. \& POL'Y 1, 15 (2001) ("[C]ontemporary civil law shows an awareness of the limits of law, avoiding excessive casuistry and introducing general clauses of good faith and equity in the civil codes."); see also id. at 17 (referring to the numerous reforms to the Argentinean Civil Code, restricting its individualistic approach, which show a shift "towards social values introducing provisions about the theory of abuse of law, the rebus sic sanctibus clause and the principle of good faith and equity").

${ }_{139}$ See Códıgo CIviL [CóD. CIV.] art. 24 (Chile) (providing that, where the Civil Code rules on legal interpretation are not applicable, obscure or contradictory passages in the laws must be interpreted in a manner that more resembles the general spirit of legislation and natural equity (author's interpretation)). 
adopted a weakened position in Latin American civil law jurisdictions, as the adoption of revolutionary ideas deprived countries of the wealth that AngloAmerican law had to offer in the form of equitable remedies. ${ }^{140}$ In sum, an intricate communication between the notion of the judicial role in a society and the recognition of judicial powers rooted in equity exists. As the Revolution curtailed the former, Latin America endured a fall from grace for the millenary concept of equity, ${ }^{141}$ where judicial inefficiency and low selfesteem still go hand-in-hand.

\section{PROMOTION OF THE DEMOCRATIC SYSTEM OF GOVERNMENT AS THE SUPREME FORM OF GOVERNMENT}

The Revolution advanced the democratic system, based on the majority rule, as the highest system of human government. This political scheme was clothed with an aura of sacredness such that any attempts at proposing alternative organizational forms for political societies, at least in the West, has amounted to anathema after the Revolution.

The democratic proposition is founded on the notion that the will of the majority defines what is true, just, and good in society. ${ }^{142}$ Therefore, democracies should be the best system of government because they embody the principle of popular representation and a universal vote.

However, a closer look at the democratic principle advanced by the Revolution clearly reveals hidden flaws. Specifically, and counterintuitively, a direct link between the democratic ideal and the notion of authoritarian democracy in Latin America exists. ${ }^{143}$ Once the will of the

140 See Phanor James Eder, A Comparative Survey of Anglo-American and LatinAMERICAN LAW 66-85 (1950) (commenting on the equitable remedies generally available in common law, such as the principle that equity presumes that is done which ought to be done, equitable conversion, laches or unclean hands, estoppel, specific performance, and the broad availability of injunctions); see also Sergio Bermudes, Administration of Civil Justice in Brazil, in CIVIL Justice IN CRisis: Comparative Perspectives of CIVIL Procedure 352 (Adrian A.S. Zuckerman ed., 1999) ("Provisional relief by injunction is not available as a matter of course from the courts in most forms of proceeding.")

${ }_{141}$ See Rolf Knütel, Derecho Romano y Codificación del Derecho Civil, Lecture at the International Congress "Diritto Romano, Diritto Cinese e la Codificazione del Diritto Civile," Beijing 3 (Oct. 3-6, 1994) (affirming the traditional core role that aequitas [equity] fulfilled in traditional Roman Law).

${ }^{142}$ STANLIS, supra note 42, at 239 (referring to the "fundamental dogma of the French Revolution-that the general will of the people at large was the sole legitimate criterion for making changes in society and the only allowable basis for sovereignty in government").

${ }^{143}$ M.C. Mirow, Borrowing Private Law in Latin America: Andrés Bello's Use of the Code Napoleon in Drafting the Chilean Civil Code, 61 LA. L. REv. 291, 306 (2001) (commenting on the authoritarian democratic regimen installed in Chile under the influence of French Revolution-inspired Andrés Bello's Civil Code). 
majority has been established, since it is assumed that it expresses the will of the people at a given time and is based on a secular notion of natural law, it cannot be contested without depriving critics of legitimacy. ${ }^{144}$ From this premise, minorities can be easily excluded, whether for political reasons or otherwise, enjoying no right or voice in the political system in accordance with the original revolutionary ideal of democracy.

These French revolutionary constitutional ideas have had a substantial impact on Latin America since the turn of the nineteenth century. ${ }^{145}$ In fact, Venezuela's 1811 Constitution, for example, "represented one of the first significant documents inspired by French ideology." 146

Later constitutional developments in the Latin American region show a movement toward the inclusion of minorities, whatever their nature or scope, and away from the revolutionary ideals. ${ }^{147}$ Nevertheless, these amendments are tainted by the revolutionary ethos. In other words, to achieve the dual purpose of recognizing minorities while maintaining the democratic goal, the status quo shaped by French revolutionary ideas in Latin America had to change. A revolution against the Revolution raised the banner of minority rights long excluded under the aegis of the cataclysmic movement of 1789 .

The revolutionary constitutional ideas on democratic legitimacy also established the paternalistic state, ${ }^{148}$ which is understood as an omniscient entity that recognizes no limits to its power, simply because it is an expression of the majority. Unsurprisingly, Montesquieu sustained that "democracy has two excesses to avoid: one is the spirit of inequality, which leads to aristocracy or monarchy, and the other is the spirit of extreme equality, which leads to despotic power."149 Indeed, after the end of colonial rule, democratic experiments led to precisely the type of dictatorial power identified by Charles de Secondat. He never explained the exact meaning of

\footnotetext{
144 STANLIS, supra note 42, at 66 ("[F] or [Edmund] Burke 1789 was a 'revolution in dogma'; it was 'a total departure . . . from every one of the ideas and usages, religious, legal, moral, or social, of this civilized world.' ").

${ }^{145}$ Mirow, supra note 11 , at 181 ("[M] any new constitutions made direct references to legal reform, specifically codification.").

146 Roberto Gargarella, The Constitution of Inequality. Constitutionalism in the Americas, 1776-1860, 3 INT'L J. CONST. L. 1, 2 (2005).

147 See generally The Explosive Apex of Evo's Power; Bolivia's Presidential Election, ECONOMIST, Dec. 12, 2009; Frank Bajak, Power of Indian Majority to Shape Bolivia Election, Bos. GloBe, Dec. 5, 2009, at 4; Bret Gustafson, Manipulating Cartographies: Plurinationalism, Autonomy, and Indigenous Resurgence in Bolivia, 32 ANTHROPOLOGICAL Q. 985 (2009).

148 Farer, supra note 34, at 1301 (commenting on the "paternalistic rule" affecting Latin American political systems).

149 CHARLES DE SECONDAT, supra note 73, at 110.
} 
his term "spirit of extreme equality." 150 Thus, as Latin American societies emerged from colonial times based on the concept of class and status, the powerful found the Enlightenment to be the "perfect" political doctrine to keep the masses at a close range. Enlightened Montesquieu, whose legal philosophies literally shaped the West, gave the leaders of the nascent republics exactly what they were looking for.

What lies at the very center of the Montesquieuan concept of the legal order is a deep distrust toward the people. These misgivings were amply shared by the other luminary of the French Revolution, Jean-Jacques Rousseau. ${ }^{151}$ Since the mid-nineteenth century, probably not a day has passed without a Latin American constitutional decision citing the legal theories of the French revolutionary ideologues. ${ }^{152}$ Rousseau is one of the main flag-bearers amongst them.

A scholar neatly summarized Rousseau's constitutional "legacy" in Latin America as:

a statist view of society where the will of the people replaced the will of the monarch; from absolute subjects to absolute citizens without space for private initiative; lack of accommodation for political differences; transition political intolerance expressed in the exile of opponents, and paving the road for insurgence as the only alternative to political participation for those not in power; and an endemic inability to dialogue with political opponents. ${ }^{153}$

Another consequence of the revolutionary democratic model, grounded on the idea of an infallible will of the majority, has been a wide sacrifice of individual rights in the name of collectivity. ${ }^{154}$ The French revolutionaries deeply held the constitutional notion that democratic representatives of the people hold a free mandate, and that the right to suffrage can be restricted on

${ }^{150} I d$.

151 Jean-Jacques Rousseau, The Social Contract 73 (G.D.H. Cole trans., 2005) ("[W]ere there a people of gods, their government would be democratic. So perfect a government is not for men.").

${ }_{152}$ See supra note 8 and accompanying text (sustaining the validity of Jean Jacques Rosseau's definition of national sovereignty as one of the arguments for upholding its decision to repeal a constitutional provision banning the sitting President of the Republic and other representative officers of government to run for reelection).

${ }_{133}$ David Jordan, Latin American Constitutionalism, in THE U.S. Constitution AND THE CONSTITUTIONS OF LATIN AMERICA 37 (Kenneth W. Thompson ed., 1991).

${ }_{154}$ See generally INDIVIDUAL AND COLLECTIVE RESPONSIBILITY 25, 134 (Peter A. French ed., 1998) (analyzing the social compact notions which have permeated some of the massacres committed in the name of the "collectivity" during the twentieth century). 
some basis. ${ }^{155}$ The rationale used by French ideologues seems to have been that, as the nation, to whom all political power belongs by virtue of absolute sovereignty, ${ }^{156}$ is a rather abstract entity, and that the legitimate representatives of the nation assume all absolute power in accordance with their mandate. ${ }^{157}$

Another aberration was included in the brood of the French Revolution's constitutional legacy to Latin America: the institution of the referendum and initiative conceived as "transfers" of lawmaking power from the government to the people. ${ }^{158}$ This transfer "back" may only be explained by a previous "divestment" of the people's sovereignty and its deposit into the coffers of the legislature. ${ }^{159}$ What other monstrous theory-undemocratic in nature-could have triggered so many damaging consequences to the Latin American democratic experiment other than the "elitist" and "enlightened" Revolutionary concept of democratic supremacy?

France has been oftentimes cited as a good example of a functioning constitutional system, and its system of government praised as a model for Latin American nations. ${ }^{160}$ At this point one may only wonder if the institutional flatterers blinked at the fact that France has had at least eleven constitutions since 1791, and it took more than good wishes to liberate la France from the claws of Nazi Germany and its pawn, the Vichy Régime, during World War II.

Contemporary modifications to the revolutionary model of constitutional democracy include the postulates that all citizens are politically equal and exercise their rights through universal suffrage; that political representatives carry out the will of the people; that citizens enjoy a long cadre of second and third generation rights at the constitutional level; that it is the duty of the government to promote social welfare; and that civil society demands an

\footnotetext{
155 Albert S. Golbert \& Yenny Nun, Latin American Laws and Institutions 43 (1982).

156 BASDEVANT-Gaudemet \& Gaudemet, supra note 51, at 328 ("Dans les doctrines révolutionnaires, l'importance donnée au concept the souveraineté demeure aussi fondamentale.") ("In the revolutionary doctrines, the importance given to the concept of sovereignty remains equally fundamental." (author's translation)).

${ }^{157}$ GOLBERT \& NUN, supra note 155 , at 42.

158 MERRYMAN \& PÉREZ-PERDOMO, supra note 69, at 25 ("Another complicating factor is the inclusion of the initiative and the referendum in the constitutions of some civil law countries; this necessarily involves the transfer of some lawmaking power from the legislature to the people, and further weakens the position of the legislature as the sole source of law.").

${ }_{159} 1$ d.

160 See Furnish, supra note 9, at 237 (commenting on Mexico's legal system as tracing "its lineage from the Romano-European traditions of the Civil Law, through the French Civil Code of 1804").
} 
ever-increasing role in the civitas. ${ }^{161}$ Yet these developments have been nothing but the late corrections of a flawed original design.

\section{CONCEPT OF ABSOlute STATE SOVEREIGNTY AND EXALTATION OF NATIONALISM}

The modern concept of the nation-state was not born in Europe until after the Reformation. ${ }^{162}$ This movement rejected the Catholic Church as the universal moral authority, and established the State as the "supreme spiritual and moral, as well as political authority and reality ... [affirming also that] outside this One Sovereign there is nothing." ${ }^{163}$ The denial of a central moral authority in Christendom yielded to the affirmation of the local and national spheres. This divergence from Europe's spiritual background arose alongside with the affirmation that temporal authority belongs to the modern nation-state. Eventually, this highly politicized view of the national sovereignty merged with the Rousseaunian statist view of society. ${ }^{164}$ This Rousseaunian construct of the statist view of society holds that the sovereign (the government, the State) has no counter powers. In other words, the negation of a universal moral authority implies the affirmation of partial authorities, each with its own source of legitimacy and strength. ${ }^{165}$

This view has generated enormous casualties worldwide during the twentieth century alone. Many, if not all, of the devastating wars fought in Europe during the last two hundred years had a nationalistic overtone at their root. From the onset, the modern nation-state recognized no outer limits or restrictions upon its activities, regardless of whether these originated from international law, or customary law, or international legal principles. No external decision, commitment, or influence could be legitimately exerted over the nation without its consent.

By affirming their absolute sovereignty, states have justified massive violations of human rights or even genocides. In fact, governments

\footnotetext{
161 GOLBERT \& NUN, supra note 155 , at 43.

${ }^{162}$ BELLOC, supra note 80 , at 109 (affirming that the "[r]eformation has been called in a biting epigram 'a rising of the rich against the poor' "); see also HILAIRE BELLOC, ESSAYS OF A CATHOLIC 65 (1931) (referring to the enrichment of the English squires during the Reformation).

${ }^{163}$ Neuhaus, supra note 53, at 85 , quoting John C. Murray, The Church and Totalitarian Democracy, 14 THEological STUDies 531 (1952).

${ }^{164}$ See id. at 92 ("Rousseau's mythology of a 'general will' of which the state is the expression.").

165 See generally Patrick Collinson, The Reformation: A History 210 (2003) ("The legacy of the Reformation was two different Protestantisms... the theologically and institutionally distinct Lutheran and Calvinist traditions.").
} 
oftentimes have argued their "sovereign" right to determine what happens within their frontiers, and have denied the right of any other state or international organization to influence their behavior. The extreme concept of national sovereignty, born at the time of the Revolution, gave way, eventually, to extreme nationalism in Europe. The State emerged as a unique source of law, recognized no restrictions based either on natural law, or in international law, without its consent.

Latin American nations followed suit and, also during the last two centuries, have waged wars amongst themselves, based in great measure, upon the revolutionary concept of absolute State sovereignty.

\section{DOCTRINE OF Strong SEPARATION OF POWERS}

One of the main protests of the French revolutionaries, against the ancien régime, was the consolidation of all powers of government into the sovereign; that is, the king. Therefore, while a total separation of governmental powers was advocated from the beginning, the three powers did not emerge as having the same strength. In fact, the French Revolution never advocated for what is known in the American constitutional experiment as a "check-and-balances" system. ${ }^{166}$ This is an American idea. No such a thing as Marbury v. Madison ${ }^{167}$ existed in revolutionary France.

As it is well known, the Latin American wars of independence gave way to legal and political systems often based on, an absolute, personalist ${ }^{168}$ executive branch. As the new regimes sought to consolidate their power, they found in the French revolutionary constitutional ideas, the philosophical and legal substratum for their goals. Latin Americans needed a constitutional system of checks and balances that the French Revolution had not provided. ${ }^{169}$ In due course, executives invoked the principle of strong separation of powers and rejected any encroachments from the other two branches.

${ }^{166}$ Luz Estella Nagle, The Cinderella of Government: Judicial Reform in Latin America, 30 CAL. W. INT'L L.J. 345, 358 (2000) (stating that the constitutions of the new Latin American countries established a rigorous Montesquieuan principle of separation of powers).

167 See Marbury v. Madison, 5 U.S. (1 Cranch) 137 (1803) (providing a foundation for judicial review).

${ }_{168}$ Gargarella, supra note 146, at 12 (describing Bolívar's reaction to a speech delivered in Angostura, at the opening of the second national congress of Venezuela, where Bolivar stated, "[L]et us put aside the triumvirate, which holds the executive power and center it in a president. We must grant him sufficient authority to enable him to continue the struggle against the obstacles inherent in our recent situation, our present state of war, and every variety of foe, foreign and domestic, whom we must battle for some time to come.").

${ }_{169}$ Nagle, supra note 166, at 352 (highlighting the lack of an effective "check-and-balances" system among the branches of government in the newly independent Latin American nations). 
On the heels of the French Revolution, for example, the Venezuelan Constitution of 1811 explicitly prohibited one branch of government encroaching into another. ${ }^{170}$ The principle of separation of powers promptly evolved (or rather degenerated) into an absolute division or "walling" amongst the branches of government. In this context, strongmen have cracked down on the opposition by means of "legislative" decrees, unilaterally written by them, imposing restrictions on individual freedoms, and targeting political opponents. Also, oppressive executives have screened off the legislative and judicial branches from interfering with these regulations. The claim to legitimacy has been founded on the strong separation of powers doctrine, furthered by the lack of a system of "checksand-balances."

The Greek tragedy of the French revolutionary absolute separation of powers doctrine, that was applied to Latin America upon its independence from colonial power, is best illustrated by the particularities related to the generation, implementation, and enforcement of legislation. There have been enormous fights among the branches of government. This inner struggle for power in Latin America has been staged in parliamentary dictatorships, and also with the Supreme Court removing the heads of the Executive branch. ${ }^{171}$

In sum, the principle of strong separation of powers has not allowed active cooperation between peer offices of government. The newly-formed Latin American nations saw their branches of government in a constant struggle to gain supremacy over one another; a situation that continues today. Interestingly, the French concept of coup d'état, born during the early years of the Revolution, does not have an accurate translation into other languages. ${ }^{172}$

\footnotetext{
${ }^{170}$ Constitución Federal [Federal Constitution] of December 21, 1811, art. 189, available at http://www.cervantesvirtual.com/servlet/SirveObras/02461 621981246052976613/index.htm (“Artículo 189. Los tres departamentos esenciales del Gobierno, a saber: el Legislativo; el Ejecutivo y el Judicial, es preciso que se conserven tan separados, e independientes el uno del otro.") ("The three essential departments of the Government are: the Legislative; the Executive, and the Judicial, [sic] it is necessary that they be preserved very separate and independent the one from the other." (author's translation)).

171 For an analysis of the constitutionality of the removal of the President of Honduras by the Supreme Court of Justice and Congress, see Honduras: Constitutional Issues and Authorities, LIBR. CONG., http://www.loc.gov/law/help/honduras/index.php (last visited Mar. 20, 2011).

${ }_{172}$ Marvin Perry et al., Western Civilization: IdEAS, Politics \& Society 483-84 (2009) (discussing Napoleon's coup d'état against the Directory on November 9, 1799).
} 


\section{ABSOLUTE SUPREMACY AND MONOPOLY OF THE STATE CONCERNING LEGISLATION}

The revolutionary doctrine (i.e., a set of principles, ideology, and values) of holding a total wall of separation amongst the branches of government came to merge itself with the novel notion justifying the legitimacy of state action grounded on secular natural law. Both the principles of absolute separation of powers and legislative supremacy generated the theory that what is legal, for being an emanation from the sovereign, is legitimate and just. As the law derives from the legislature, the predominant organ of government, every action of the sovereign, that is, of the legislative branch, is clothed in a cloak of legitimacy. As one scholar puts it, "[a] cardinal tenet of the French was that all law-making power was to be vested in a representative assembly." 773 The law came to be presumed fair, just, and legitimate. ${ }^{174}$ All the powers of government are to back-up that notion with the strength of reason and, if necessary, of the sword. The inhabitants of the State, the Revolution proclaimed, became citizens qua members of the State; that is, their identity and membership in the community was determined and dependent upon their participation in the State. ${ }^{175}$

These ideas rapidly propagated around Europe in the early nineteenth century ${ }^{176}$ giving way in Latin America to the strong influence of the European absolute state and "not the constitutional parliamentary model that England gave to America." "177 From Europe, these theories spread into the Latin American region, where the theory of separation of powers never became a reality. ${ }^{178}$

As previously noted, the doctrine of absolute State power, founded on the concept of sovereignty, knows no limits as to the areas and extensions where

\footnotetext{
173 MERRYMAN ET AL., supra note 92, at 193.

174 See Merryman \& PéreZ-Perdomo, supra note 69, at 21 ("The legislative act was subject to no authority, temporal or spiritual ... sovereignty had two faces, an outer face that excluded any law of external origin and an inner face that excluded any law of local or customary origin.").

175 NeuHaus, supra note 53, at 128 (mentioning that when the State "owns" the right to determine who is a citizen and who is not, the "habit of beheading people for not being citizens" begins).

${ }^{176}$ Bernardo Periñán, A Romanistic Approach to Unified European Private Law, 4 ROMAN LEGAL TRADITION 104, 107 (2002), available at http://www.romanlegaltradition.org/contents/ 2002/RLT-PERINAN1.PDF (commenting that "[a]fter the French Revolution, on the other hand, Law was identified with 'the Law,' setting aside doctrinal and jurisprudential tradition in the interest of greater legal certainty. These ideas which took form in the Constitutions and codifications of the nineteenth century permeate most European societies.").

177 Jordan, supra note 153, at 34.

178 Id.
} 
the government may legislate. By giving the political majority its substratum in the legislature, the legislative branch is empowered to go into the citizens' bedrooms, kitchens, living rooms, and bank accounts, and to regulate intermediate social, religious and other organizations without any restriction. Nothing in society escapes the reach of the State, and the whole of the community becomes subject to its supreme power under this doctrine. ${ }^{179}$ The government holds a total monopoly over communal life as well.

The traditional legislative supremacy doctrine has been eroded and somehow, even repudiated in its cradle, France, during the last fifty years after World War II. ${ }^{180}$ One scholar identifies two of the main elements in this phenomenon, particularly in the aftermath of the 1958 Constitution. ${ }^{181}$ First is the case of the executive's autonomous legislating power by means of Article 37, according to which matters other than those reserved for the legislative domain are of an executive character. And second, the slow abandonment of revolutionary constitutional orthodoxy is the delegation of legislative power into the executive to issue administrative regulations. ${ }^{182}$ However, mainstream French constitutional authors think the strict principle of separation of powers has not been derogated by these recent developments. Despite the fact that the evolution has not altered the traditional pattern of State supremacy, they argue that, in reality, the primacy of the executive branch has been broadly reaffirmed with these innovations. ${ }^{183}$ At any rate, the original design of the revolutionaries is still malum consilium quod mutari non potest ("it's a bad plan that cannot be

179 Levasseur, supra note 108, at 773 ("Whatever is not contrary to legislation is licit.").

180 See generally Edward J. Pauw \& Ari Chaim Shapiro, Defamation, the Free Press, and Latin America: A Roadmap for the Inter-American Court of Human Rights and Emerging Democracies, 30 U. MIAMI L. REV. 203-41 (1998) (mentioning certain innovations in the French parliamentary-presidential system-or semi-presidentialism-including, among others: a dual executive; a president elected by popular vote; the appointment of the head of government by the president without parliamentary approval; the possibility of removal of the government by parliament; the power of the president and prime minister to dissolve the legislature and call new elections; the lack of presidential veto power over parliamentary action; and the delegation of legislative functions to the president, who then may legislate by decree).

181 Rogelio Pérez-Perdomo \& Lawrence Friedman, Latin Legal Cultures in the Age of Globalization 3 (2003) ("France... brought General de Gaulle to power in 1958, inaugurating a period of personalist democracy.").

${ }_{182}$ MERRYMAN ET AL., supra note 92, at 194 (discussing that, even though France created the Constitutional Council, with power to review the constitutionality of parliamentary legislation, and the Council of State, the constitutionality of executive legislation, "these changes conferred upon the executive a privileged position in the parliamentary law-making process").

${ }^{183}$ MerRyMAN \& PÉREZ-PERDOMO, supra note 69 , at 193-94 (discussing the changes brought about by the French Constitution of 1958 which meant a strengthening of the powers of the Executive Branch in that country after World War II). 
changed"). ${ }^{184}$ And from the time of independence, Latin American nations have followed suit in the sense that legislation has become "the work of the Ministry of Justice and other departments."

As power begets power, and the sovereign does not often willingly take criticism, truth becomes the first victim of absolute power. If truth in society is still a value, then the press has a role to fulfill in the polis. Accordingly, the sovereign has imposed restrictions on the freedom of the press and other related freedoms in the name of democratic legitimacy.

In a nutshell, history, at least in Latin America, has shown that a straight path exists from the French revolutionary doctrine of absolute separation of powers to widespread limitations on individual freedoms in nominem (in the name of) of State supremacy and sovereignty.

\section{LACK OF CONSTITUTIONAL EMERGENCY POWERS ${ }^{186}$}

The independence of Latin American countries was very violent, due to the fact, in part, that the Spaniards were militarily strong. Unlike the inexperienced revolutionary Creole armies, the Spaniards had known victory after victory, after defeating the Turks in Lepanto and gaining control over the Mediterranean in the Middle Ages. ${ }^{187}$ They were strong and very seasonable warriors. It was not just a few shots that were fired as it happened in Concord, Massachusetts, in 1776. ${ }^{188}$ The Latin American wars of independence, instead, were fought in huge strongholds and fortifications, ${ }^{189}$ and much blood spilled during those years.

After the Spaniards were expelled from Latin America, there remained different factions amongst the independentists. On the one hand, those

\footnotetext{
184 Author's translation.

185 MERRYMAN ET AL., supra note 92, at 194.

186 "States of Constitutional Emergency" refers broadly to the suspension of constitutional guarantees and freedoms. It is worth mentioning that the French Constitution of 1791 does not include a chapter or particular provisions on constitutional emergency powers; see supra note 4 and accompanying text.

187 See angus Konstam, Lepanto 1571: The Greatest Naval Battle of the RENAISSANCE 38 (2005) (describing the central military role of the Spanish Empire in the Holy League).

188 See generally EdWARd L. AYERS ET AL., AMERICAN PASSAGes: A History OF THE UNITED STATES 106-09 (2009) (reviewing the details of the the battles of Lexington and Concord, within the context of the War of Independence of the American colonies during the period 1775-1776).

${ }^{189}$ Miguel Schor, Constitutionalism Through the Looking Glass of Latin America, 41 TEX. INT'L L.J. 1, 14-15 (2006) ("Independence in Latin America was followed by unrelieved civil war for almost half a century throughout most of the continent whereas the United States enjoyed a series of peaceful presidential transitions throughout its history and did not face a civil war until the middle of the nineteenth century.").
} 
nursed in the Revolution despised everything that was Roman ${ }^{190}$ or Catholic. ${ }^{191}$ For them, a new world was supposed to emerge, with reference to nothing from the past. They created a new order, and in that sense, everything that was Roman, or based on the Roman heritage, had to go. ${ }^{192}$ The other faction consisted of those who rejected the political dominance of the Continent, but desired to preserve the ancient cultural and religiouslyinspired institutions under which they had lived and prospered for generations. ${ }^{193}$

Upon independence, the winning factions in the former Spanish colonies, rejected the influence of Spain, the former colonizing Empire. In doing so, they had to resort to some other model to shape their nascent constitutional and legal systems. They looked at the United States, but that model was too new, untested, and still unsettled, as it was immersed in a struggle between federalists and republicans. French ideas came over from Europe, as the liberators of Latin America had strong connections to the Continent. Bolívar and most leaders of the Independence, for example, were educated in Europe, mostly in France. ${ }^{194}$ Bolivar, himself, attended the crowning of

190 See Shael Herman, The Uses and Abuses of Roman Law Texts, 29 AM. J. ComP. L. 671, 672 (1981) ("Both the French doctrinal writers and code drafters rejected many aspects of Roman law, and they either transformed or tailored key concepts they allegedly 'borrowed' to fit the social and political order of post-Revolutionary France.").

${ }^{191}$ On the French Revolution's stand toward the Catholic Church, see generally JACQUES FrançoIs Lefranc, Le Volle Levé Pour les Curieux, OU, Le SeCret de LA ReVolution de FraNCE 77-94 (1816) (see, e.g., Chapter VII Les Frank Maçons veulent abolir la Hiérarchie Ecclésiastique, dans l'Eglise Catholique [The Frank-Masons want to abolish the Ecclesiastical Hierarchy in the Catholic Church] (author's translation)); JoHN MCMANNERS, THE FrENCH REVOLUTION AND THE CHURCH (1982) (reviewing the multiple attempts in all spheres of life undertaken by the French revolutionaries to annihilate the Catholic Church, concerning, among other, her doctrine, structure, property, public standing in society, concepts of the sacred, liturgy, festivities, etc.); ClaUde GEFFré \& JEAN-PIERrE JosSUA, 1789: THE FrENCH REvolution AND THE CHURCH 36 (1989) (stating, for example, that "1795 and 1796 were years propitious to the construction of a republican Christianity, purged by the dechristianising persecution"); see also STANLIS, supra note 42, at 175 ("Burke attacked the French revolutionists who naïvely supposed the violent destruction of evil kings and priests would result in universal peace."); Rosmini, supra note 66, at 1402 (recalling that Napoleon Bonaparte stated that modern philosophers "undertook every effort to persuade France that the Catholic religion was the implacable enemy of every democratic system").

${ }^{192}$ It is important to remember at this point that the National-Socialist Party Program included the demand that "Roman law, which serves a materialistic world view be replaced by a common German Law." Periñán, supra note 176, at 111.

${ }_{193}$ JAKSIĆ, supra note 6, at 178 (stating that, referring to the ruling classes of Chile, Andrés Bello is reputed to have said in 1836 that "people are less zealous about the conservation of their political liberties that about the conservation of their civil rights [and the perceived view that the] ability to participate in public affairs is infinitely less important than the ability to secure life and property").

${ }^{194}$ Mirow, supra note 11, at 183 ("French culture ruled Latin American culture and the élite 
Napoléon, and owned the largest Napoleonic library outside of France. ${ }^{195}$ The Chilean Liberator, Bernardo O'Higgins, attempted to rubber stamp the French Civil Code in Chile. Simón Bolívar, whose tutor was Andrés Bello, and the author of the most influential Civil Code in Latin America, ${ }^{196}$ deeply admired the Code Napoléon. ${ }^{197}$

In sum, the French Revolution had a great impact on shaping the legal systems, not only at the time of the Latin American independence movement, but this influence is still felt throughout the region. After all, it was France that had provided Latin America with the model for private law in the form of the Civil Code, of which Napoléon said would endure forever. ${ }^{198}$

As they had with the Civil Code, Latin Americans borrowed greatly from the French revolutionary constitutional mold. Consequently, when the new Latin American nations gained their independence, they looked at France for models in the realm of private law, but also sought to imitate France's constitutional law paradigm. The rationale was that, since France had the prestige to formulate the Civil Code, she was also thought to have the stature to give Latin America its constitutional model.

However, when the time came to follow guidelines relating to constitutional emergency powers, they found that France did not provide a model. $^{199}$ In effect, this omission was deliberate. The Revolution denied the branches of government emergency or discretionary powers altogether. Montesquieu had expressly rejected that discretionary powers be granted to the branches of government, because it would have involved the destruction,

of Latin America were a Francophone élite ... ruling classes of Latin America intellectually aligned themselves with the French intelligentsia and saw French progress somehow more in tune with Latin American cultural and societal aspirations.").

195 M.C. Mirow, The Power of Codification in Latin America: Simón Bolivar and the Code Napoléon, 8 TUL. J. INT'L \& COMP. L. 83, 97 (2000) ("[T]he books in Bolívar's library that formerly belonged to Napoleon were given special mention in Bolívar's testament .....").

196 Murillo, supra note 138, at 9 ("[T] adopted virtually in its entirety in Ecuador (Civil Code of 1860) and Colombia (Civil Code of 1873), while Argentina, Paraguay, Uruguay, Honduras, Venezuela, El Salvador and Nicaragua adopted specific provisions in their own civil codes.").

${ }_{197}$ Bolivar has been quoted as saying: "The Liberator President is highly aware of the wisdom with which the Code Napoleon was drafted." Letter from José D. Espinosa, General Secretary to Bolívar, to José Manuel Restrepo, Minister of the Interior (May 13, 1829), cited in Mirow, supra note 11, at 179.

${ }^{198}$ Lobingier, supra note 101 , at 133 ("Ma vraie glorie n'est pas d'avoir gagné 40 batailles. Ce que rien n'effacera, ce que vivra eternellement, c'est mon Code Civil.") ("My true glory is not in having won forty battles; Waterloo will blot out the memory of those victories. But nothing can blot out my Civil Code. That will live eternally." (author's translation)).

${ }^{199}$ See supra note 186; see also MERRYMAN \& PÉREZ-PERDOMO, supra note 69, at 206 (noting that the Norwegian legal doctrine admits that the idea of "emergency constitutional law," serves to legitimize irregular constitutional acts such as the secession from Sweden). 
or at least the posing, of commensurable threats to the doctrine of strict separation of powers. ${ }^{200}$

The fact that the French constitutional revolutionary model stemming from the very Constitution of 1791 lacked of a well-defined institutional structure dealing with constitutional emergencies went clearly against the Western legal tradition, where Roman law presented a model concerning constitutional emergencies. ${ }^{201}$ The importance of making a reference to the Roman model lies in that it was the only procedure for tackling constitutional emergencies in the West, up to the period of the French Revolution. ${ }^{202}$ In effect, Romans had the "constitutional dictatorship" model. ${ }^{203}$ According to this constitutional system, in cases of emergency, a dictator was appointed. ${ }^{204}$ The appointment procedure involved intricate stages, starting with the declaration of a period of emergency by the Senate, and the designation of two consuls. ${ }^{205}$ The consuls, in turn, appointed the dictator, who could not be a senator or a consul, for a specific period of time. ${ }^{206}$ The dictator usually would be a magistrate, detached from the political process, who could suspend constitutional guarantees as part of his emergency powers only for six months. ${ }^{207} \mathrm{He}$ could not take permanent measures, or imprison any of the members of the other powers of the State. ${ }^{208}$ Once the emergency period was over, the constitutional order was reestablished. ${ }^{209}$

Therefore, the French revolutionary constitutional theory passed into Latin America without a model for the exercise of emergency powers. In other words, the French model rejected such powers, and that vacuum was thought to embody a key constitutional principle of that model. Consequently, the revolutionary constitutional theory rotated around the

\footnotetext{
${ }^{200}$ Gabriel L. Negretto \& José Antonio Aguilar Rivera, Liberalism and Emergency Powers in Latin America: Reflections on Carl Schmitt and the Theory of Constitutional Dictatorship, 21 CARDOZo L. REV. 1797, 1817 (2000); see also PRESIDENTIALISM AND DEMOCRACY IN LATIN AMERICA (Scott Mainwaring \& Matthew Shugart eds., 1997) (examining the debate surrounding of whether the presidential form of government has been a major contributor to the impediments for real democracy to take root in Latin America).

201 Id. at 1815 (referring to the Roman type of dictatorship).

${ }^{202}$ Id. at 1804 (mentioning that "the 1811 Venezuelan constitution, the 1815 Argentinean charter, the 1818 Colombian constitution, and the 1824 Mexican charter did not include broad emergency powers").

${ }^{203}$ Id. at 1798 .

204 Id. at 1799.

${ }^{205}$ MCCARTHY, supra note 18, at 8 ("One of Rome's two consuls could appoint a dictator during a time of emergency.").

${ }^{206} I d$. (commenting that the dictator served "as supreme ruler during such times"-alluding to times of "war or internal struggles").

${ }^{207}$ Id. ("Rome's dictators would serve for six months.").

${ }^{208} \mathrm{Id}$.

${ }^{209}$ Id.
} 
principle of strict separation of powers, and the resulting denial of emergency powers.

This explains that, when political turmoil took place early during the independence movement, there was no model to follow. Executives appropriated the power to subdue the legislative and judicial branches, ${ }^{210}$ and in turn, acquiesced to executive claims to declare and maintain extensive periods of constitutional emergencies. ${ }^{211}$ The legislature showed virtually no opposition to such measures. ${ }^{212}$ The judiciary, likewise, ruled that constitutional emergency powers were a non-justiciable political question and, hence, to decide otherwise would have meant a serious violation of the principle of strong separation of powers. ${ }^{213}$

In sum, the logical consequences of the assumption of French revolutionary constitutional ideas in Latin America has allowed the unwarranted stance of the executive, the systematic subjugation of the legislature and the judiciary to the president, and massive human rights abuses during constitutional emergencies. In fact, Latin America has been ruled by emergency decrees and other types of transitory, emergency legislation for long periods, during the span of almost two centuries. ${ }^{214}$ In Colombia alone, during the twentieth century, a constitutional emergency lasted for about thirty years. ${ }^{215}$ All of this has happened thanks to the French Revolution's legal legacy in the region.

One hundred sixty-nine years after the Revolution, France created a system of constitutional emergencies with the Constitution of $1958 .{ }^{216}$ This is but another aspect of the so-called "French Deviation": 217 a detour from

${ }^{210}$ Nagle, supra note 166 , at 352 (referring to the status of servant that the judiciary achieved early since independence vis-à-vis juntas; that is, governments run by strongmen, usually after a military intervention).

${ }^{211}$ Id. (proposing that "the political patronage and turnmoil plaguing Latin America after independence [caused that] instead of the judiciary being the objective branch and balancing and neutralizing the power of the political branches, it became their servant").

${ }_{212}$ Id.

213 Id. at 351,358 .

214 Id. at 352.

215 Negretto \& Rivera, supra note 200, at 1807 ("Colombia was ruled under emergency provisions for almost three-fourths of the time between 1958 and 1988.").

${ }_{216}$ See generally DE GUILLENCHMIDT, supra note 97, at 334-38 (expounding the operation and ramifications of Article 16 of the Constitution of 1958, and highlighting the lack of constitutional control prior to that date); THIERRY S. RENOUX, CODE CONSTITUTIONNEL 37072, 436-37; see also ANNE-MARIE Le POURHIET, Droit ConstitutionNel 342-46 (2007) (analyzing the ramifications of Article 16 of the Constitution of 1958, which deals with constitutional emergencies).

217 Garcia, supra note 100, at 1283 (quoting John Henry Merryman, The French Deviation, 44 Ам. J. ComP. L. 109, 111 (1996)). 
the principles of the Revolution, which changes nothing of the original revolutionary ideology of lack of constitutional emergency powers.

\section{DIMINISHED ROLE OF THE JUDICIARY}

Montesquieu, the true author of the misery that was to befall over the French judiciary and all of its post-1789 progeny, described the role of the judiciary in the new model in the following terms: "In republics, the very nature of the constitution requires the judges to follow the letter of the law; otherwise the law might be explained to the prejudice of every citizen, in cases where their honor, property, or life is concerned." ${ }^{218}$ The judiciary was thought to be subservient to the monarchy by the time of the Revolution. Since it was not possible for the Revolution to eliminate this "multitude of tyrants" 19 altogether, the Code Civil of 1804, itself an upshot of the Revolution, ${ }^{220}$ included particularly stringent provisions delimitating the role of judges. ${ }^{221}$ Namely, Article 5 established that judges are forbidden from issuing general dispositions in the cases adjudicated by them. ${ }^{222}$ The technical device of legislative referral (référé législatif) $)^{223}$ was conceived for cases repeatedly decided by the judiciary where no legislative solution existed. $^{224}$ Not even in those cases was precedential value recognized in judicial decisions. ${ }^{225}$ In the Montesquieuan ideology, judges were to become

218 Charles de SeCONDAT, supra note 73, at 75.

219 MERRYMAN \& PÉREZ-PERDOMO, supra note 69, at 126.

220 Lecture 15: "Europe and a Superior Being: Napoleon," HIST. GuIDE, http:/www.histor yguide.org/intellect/lecture 15a.html (last revised Feb. 8, 2006) ("There is no denying the fact that the French Revolution created Napoleon.").

221 MERRYMAN \& PÉREZ-PERdOMO, supra note 69, at 133 (stressing the aversion of Continental lawyers toward single-judge courts, "Juge unique, juge inique") ("A single judge, a unique yoke" (author's translation)).

${ }^{222}$ CODE CIVIL [C. CIV.] art. 5 (Fr.) ("Il est défendu aux juges de prononcer par voie de disposition générale et réglementaire sur les causes qui leur sont soumises.") ("It is forbidden to judges to decide the cases subject to their jurisdiction by means of general and reglamentary dispositions." (author's translation)).

2231791 CONST. tit. III ch. 5, para. 21 (Fr.), available at http://sourcebook.fsc.edu/history /constitutionof1791.html ("When, after two cassations, the judgment of the third court is protested in the same manner as the first two, the question may not be discussed further in the Court of Cassation without having been submitted to the legislative body, which shall pass a decree declaratory of the law, to which the Court of Cassation shall be required to conform."). The legislative referral was eliminated by law on June 27,1800 , but later reestablished by a law on September 16, 1807, and finally suppressed in 1837. BASDEVANT-GAUDEMET \& GAUDEMET, supra note 51 , at 427.

224 VAN CAENEGEM, supra note 21 , at 131 ("Where three tribunals persisted in judging to the same effect, the Tribunal de Cassation had to submit the question to the legislative assembly to obtain a legislative statute, which was then imposed on the judiciary at large.").

${ }^{225}$ CODE CIVIL [C. CIV.] art. 3 (Fr.) (providing that "judicial decisions are not binding but 
the "mouthpiece of the law."226 The extremely mechanical role ascribed to judges conspired to produce weak and, in many occasions, corrupt adjudication. $^{227}$

The history and reality of Latin America demonstrate that judges have traditionally been "extremely deferential" to the other two branches of government ${ }^{228}$ and thus subject to political manipulation. ${ }^{229}$ One scholar has accurately called the judiciary's self-perception as "a nearly 200 year-old inferiority complex,",230 coupled with a "self-imposed subservience to the executive branch, and to the legislative branch to a lesser degree."231 In sum, after the Revolution the judiciary emerged as a handicapped branch of government, and this legacy was passed onto Latin America, ${ }^{232}$ where the judiciary has accurately been called the "Cinderella of the public system." 233

Yet another consequence of the demolition of the judiciary at the hands of the Revolution has been that the role of interpreting the law was transferred from judges to legal scholars. Legal experts gained an unprecedented influence on adjudicatory procedures in the region. ${ }^{234}$ Thus, learned writing came to 'indirectly control [sic], to a great extent, the judges' understanding of the case law." ${ }^{235}$ The logic behind this scheme is that, since judges are not allowed to create law or rely on their own decisions or those of higher courts, learned treatises fill in the gaps by collecting and analyzing the most important cases, which in turn are relied upon by judges. ${ }^{236}$ This influence is

except with respect to the cases in which they are pronounced" (author's translation)).

${ }^{226}$ Montesquieu called judges: "inanimate beings who cannot moderate either its [sic] force or rigour." VAN CAENEGEM, supra note 21, at 123 n.16 (quoting ChARLES DE SECONDAT, THE SPIRIT OF THE LAWS (1748)).

${ }^{227}$ Baudenbacher, supra note 98, at 351 (pointing out that "judges in civil law countries tend to be career civil servants"). Id. at 358 ("Piero Calamandrei wrote in 1955 that an Italian judge has told him: 'We decided unanimously, because juridical logic required it, but when we parted we were all full of sadness.' ").

${ }^{228}$ Michael Pahl, Judicial One-Hit?: The Decriminalization of Personal Drug Use by Colombia's Constitutional Court, 6 IND. INT'L \& COMP. L. REv. 1, 51 (1995).

229 See William C. Prillaman, Chile's Coherent Approach to Judicial Review, in THE Judiciary and Democratic DeCay in Latin America: DeClining Confidence in the Rule of LAW 137 (2000); Matthew M. Taylor, Beyond Judicial Reform: Courts as Political Actors in Latin America, 41 Latin AM. Res. Rev. 279, 269-80 (2006).

${ }^{230}$ Nagle, supra note 166 , at $357-58$.

231 Id. at 358.

${ }^{232}$ Garcia, supra note 100, at 1284 ("Judicial function is 'something narrow, mechanical and uncreative,' and judges are 'unprestigious clerks at the bottom of the legal profession.' ").

${ }^{233}$ PÉreZ-PERDOMO \& FriedMAN, supra note 181 (mentioning many other evils affecting the judiciary in the region, among them, low quality recruitment and adjudication standards, corruption, bribery, and denial of justice).

${ }^{234}$ Id. at 6-9.

${ }^{235}$ MERRYMAN ET AL., supra note 92, at 209.

${ }^{236}$ Id. at 710 . 
predominantly important "when the law is unsettled, or there is no established law on a point."237

Again, unaccountable outsiders have added another layer of illegitimacy to an already incapacitated adjudicatory process, and this, thanks to the French Revolution of 1789.

\section{WEAK AND TROUBLED SYSTEM OF JUdiCIAL REVIEW}

The legal control of the activities of the other branches of government by the judiciary was hardly a preoccupation of the revolutionaries. An already diminished judiciary ${ }^{238}$ had to face reality soon after the revolutionary codes were enacted. That reality shows that the executive and the legislative branches often violate the constitution, the law, or trample upon the rights of citizens. Consequently, control over the two other branches was necessary to counteract their undue influence over judges, and also to ensure the correct interpretation and application of the law, as issued by the legislature. The alternatives were to either bestow additional powers on existing courts, or to create new tribunals.

Again, in the vein of the "French Deviation," the Cour de Cassation, created by the Constitution of 1791, had been given new powers over time. ${ }^{239}$ The Cour was conceived as dependent of, and subordinated to the legislative branch, ${ }^{240}$ to maintain the appearance of fidelity to, the revolutionary manifesto, to avoid judicial creativity and derailments in the interpretation of statutory law, and to ensure the correct application of the law. ${ }^{24}$ This organism, accordingly, "often only makes allusions to the facts" of a case. ${ }^{242}$ Cassation procedures eventually arrived in Latin America during the twentieth century. ${ }^{243}$

Consonant with the revolutionary spirit of a shackled judiciary, ${ }^{244}$ and to placate any potential activist aims of the Cour, ${ }^{245}$ the Constitution of 1791

237 Id. at 209.

238 See Pilar Domingo, Judicial Independence: The Politics of the Supreme Court in Mexico, 32 J. LATIN AM. STUD. 705, 718 (2000) (analyzing the lack of independence of the Mexican judiciary).

239 John Henry Merryman, The French Deviation, 44 AM J. CoMP. L. 109 (1996).

240 BASDEVANT-GAUdEMET \& GAUDEMET, supra note 51, at 345 ("[L]a loi plaçait the Tribunal de cassation auprès du Corps legislative.") ("The legislation placed the Court of Cassation close to the Legislature." (author's translation)).

241 See 1791 ConsT. tit. III, ch. V, paras. 19-23 (Fr.) (regulating the relationship of subordination of the Court of Cassation to the National Assembly).

242 Baudenbacher, supra note 98, at 352.

243 ANGEL OQuendo, LATIN AMERICAN LAW 272 (commenting that the Mexican cassation procedure had arrived from France via Spain).

${ }^{244}$ See T. Leigh Anenson, Note, For Whom the Bell Tolls . . . Judicial Selection by Election 
also created the institution of the référé législatif. ${ }^{246}$ This mechanism was established for cases where judicial activity would lead to statutory interpretation. ${ }^{247}$

In addition to the Cour de Cassation, a new tribunal called the "Constitutional Council" was created in $1958{ }^{248}$ This body was charged with control of the constitutionality of legislative activity. ${ }^{249}$ Allegedly, and to maintain consistency with the stated ideals of the Revolution, constitutional review was then called "political" rather than "judicial."250

The legality of administrative action, in turn, was entrusted to the Council of State. ${ }^{251}$ The Law of the Constituent Assembly of August 16-24, 1790, provided in article 13 that " $[\mathrm{t}]$ he judicial function is distinct and shall always be separate from the administrative function. Judges shall not ... interfere in any way in the actions of administrative agencies or exercise jurisdiction over administrators." 252 To maintain the little regularity that was left in the original revolutionary model of strict separation, the French envisaged the Council of State also as a non-judicial organism. ${ }^{253}$

Under the influence of the Revolution, twentieth-century France again created another tribunal, the Conflicts Tribunal, to resolve conflicts of jurisdiction between ordinary courts and the Council of State. ${ }^{254}$ Additionally, during the mid-twentieth century, France created special judicial bodies in an attempt to guarantee independence and impartiality in the appointment of judges. ${ }^{255}$

in Latin America, 4 Sw. J.L. \& Trade AM. 261, 277 (1997) (discussing the politization of judicial appointment processes in Latin America).

245 BASDEVANT-GAUDEMET \& GAUDEMET, supra note 51, at 345 (commenting that the référé is a mechanism whereby the judiciary refers a matter to the legislature whenever there is a need to interpret the existing law, or pass a new one).

246 MERRYMAN ET AL., supra note 92, at 709.

247 Id. at 706; see also Keith Rosenn, Judicial Review in Latin America, 35 OHIO ST. L.J. 785,787 (1974) (stating that "[d]eclaring legislation unconstitutional [by the judiciary in Latin America] is perceived as a political function and therefore unsuitable for the ordinary judiciary").

248 MERRYMAN ET AL., supra note 92, at 758.

${ }^{249} \mathrm{ld}$.

${ }^{250}$ Id.

251 Id. at 706 .

252 Id. at 705 .

${ }^{253}$ Id. at 729 .

$254 \mathrm{Id}$.

255 John O. Haley, Judicial Reform: Conflicting Aims and Imperfect Models, 5 WASH. U. GLOBAL STUD. L. REV. 81, 86 (2006) ("The French were the first to create a judicial council, the Conseil superior de la magistrature, for selection of judges and administration of the judiciary in the 1946 Constitution for the Fourth Republic."). 
As expected, these creationist trends affecting the judiciary have been imitated by Latin American nations, starting in the second half of the twentieth century. ${ }^{256}$ These nations created mixed systems of constitutional review, whether at the hands of supreme courts or by specially-created constitutional tribunals. ${ }^{257}$ Latin American courts, in turn, also followed suit and started releasing themselves from the doctrinal straightjacket imposed by the imported French revolutionary ideas. The main judicially-created procedural innovations include the design of constitutional writs ${ }^{258}$ to counteract the abuses brought about by executive absolutism. These novelties, however, have met strong and decisive counter-reactions from the other two branches, oftentimes creating constitutional instability and chaos.

The dangers of self-assertion and supremacy still lay hidden in the relationships between the branches of government in Latin America. This situation has been caused, to a great extent, by the constitutional legacy of the French Revolution, and its unbalanced constitutional principles.

\section{Legislative Process ConCEIVEd As a Rational AND SCIENTIFIC ENDEAVOR DETACHED FROM PRACTICAL CONSIDERATIONS}

Within the context of the Enlightenment, the French revolutionaries envisioned the legislative process as a rational and scientific endeavor disconnected from reality. ${ }^{259}$ At the core of the new movement was the belief that a few illuminati-enlightened men-may produce legislation based on pure reason that would last for many years with hardly any amendments. ${ }^{260}$ Andrés Bello, the great Latin American codifier, repeated this idea in the design of the Chilean Civil Code of $1855,{ }^{261}$ which is

\footnotetext{
${ }^{256}$ See generally MERRYMAN \& PÉREZ-PERDOMO, supra note 69, at 25 ("[T] $[$ hey insert a new element [after World War II] into the hierarchy of sources of law, which now must read 'constitution, legislation, regulations, and custom.' ").

${ }^{257}$ MERRYMAN ET AL., supra note 92, at 810 (commenting that Chile, in its 1980 authoritarian constitution, created two systems of constitutional review, one before the constitutional tribunal without the need of "cases or controversies" and prior to the promulgation of statutory laws; and the other "incidental" to judicial adjudication at the hands of the supreme court, which requires a "case or controversy"); see also F. Soibelman, Súmula vinculante na Emenda Constitucional $n^{\circ}$ 45/2004. (Teresina, a. 9, n. 618, 18 Mar. 2005) (discussing "súmulas vinculantes" in Brazil).

${ }^{258}$ See OQUENDO, supra note 243, at 290-303 (analyzing "the Judicially Created Protection Suit in Argentina").

${ }^{259}$ ERNESt A. Benians, 8 The Cambridge Modern History: The French Revolution, at v (Sir Adolphus William Ward ed., 1904) (referring to the revolutionary legislators' attempt "to break loose from the bonds of custom, convention, and tradition, and to build up a new scheme of human relations from a purely rational basis").

260 Id.

261 JAKSIĆ, supra note 6, at 154.
} 
"perhaps the most influential code in the development of Latin American private law." ${ }^{262}$ It is apparent from the principles of the Civil Code that its drafters thought that the solution for every legal problem could be derived with near mathematical certainty through a process of logical deduction. ${ }^{263}$

While it is true that Napoléon enacted the Civil Code and not the revolutionaries, the Civil Code, that magnum instrument of legal uniformity and domination, served as a formidable tool for the consolidation of the political victories in light of the totalizing revolutionary ideology. Hence lies the intimate connection between the Civil Code and the Revolution. ${ }^{264}$

The inner authoritarianism of the Civil Code is also reflected in its stated goal of comprehensiveness. Napoléon himself abhorred the prospect of having his Code become the object of expert commentary. ${ }^{265}$ The pretension to universality ${ }^{266}$ inherent in the idea of the Code Civil crashed upon inception. In fact, the first law promulgated jointly with the Code Civil is entitled, "Law on the Gathering of Civil Laws in One Body, Under the Title "Code Civil des Français.'" The inconsistency in the legislative aspiration of the Code is evident. If the Code Civil was going to encompass all possible situations where statutory law was necessary, what consistency exists if the same aforementioned law listed thirty-six laws that were "understood" to be a part of the Code Civil? Either the legislative technique was flawed, or the principle on which it was founded was unachievable. All elements of judgment and subsequent history lead to the latter conclusion. In fact, the original Code Civil of 1804 has gone through countless corrections,

\footnotetext{
262 Mirow, supra note 11 , at 183 .

263 JAKSIĆ, supra note 6, at 154 ("In Article 20 of the Código, Bello stated that 'the wording of the law is to be understood in the natural, obvious, and generalized meaning and usage of the words themselves.' The point of this emphasis was that citizens could not understand the law unless it was written in precise and grammatically sound language. Only then would they be able to read it and understand it, just as they understood the basics of day-to-day communication. Ultimately, if the law was to become common currency among citizens, it had to be easily accessible and recalled, perhaps not that much differently from how a poem could be recited thanks to meter and rhyme.").

264 BASDEVANT-GAUDEMET \& GAUDEMET, supra note 51, at 372 (stating that "the bourgeoisie and the nobility that sustain the political power of Bonaparte wish[ed] to consolidate the legal conquests of the Revolution" (author's translation)).

${ }^{265}$ Id. at $410 \mathrm{n} .7$ (citing Napoleon's words upon learning about the publication of a legal analysis of the Code by Maleville in 1805, "Un commentaire, mon Code est perdu") ("One comment, and my Code is lost" (author's translation)).

${ }^{266}$ Genaro Carrió, Judge Made Law Under a Civil Code, 41 LA. L. Rev. 993, 993 (1980) ("The sought-after ideal is that a solution to all problems and conflicts arising in such given area be found within a set of rules arranged in a rational way, free of gaps, overlappings, contradictions, obscurity and ambiguity."). The author, Carrió, goes on to call this ideal the "myth of codification." Id.
} 
additions, and amendments during the centuries. ${ }^{267}$ The enormous legislative mess present in Latin America is a direct consequence of the adoption of the Code Civil and its pretensions of totality.

Another ideal of the revolutionaries was to create legislation written and implemented in a manner that would make it accessible to the common man. ${ }^{268}$ The Enlightenment was the first fruit of philosophers and lawyers who thought highly of themselves and took every stride to differentiate themselves from commoners. As it turned out, due to the extensive borrowing of the Code Civil from Roman Law, ${ }^{269}$ the pretension of simplicity, accessibility, and easiness of reading, comprehension, and implementation went largely unfulfilled, thanks, in great part, to the French Revolution.

\section{CODIFICATION AS AN INSTRUMENT FOR BROAD GOVERNMENTAL CONTROL OF SOCIETY}

The idea of codification is an ancient concept, dating back at least to the promulgation of the Justinian Code in 534 A.D. ${ }^{270}$ Codification experiments also took place throughout Europe before the French Revolution, but only the French Civil Code achieved the stardom desired by other efforts. ${ }^{271}$ After its passage, the Civil Code triggered an almost universal codification movement. ${ }^{272}$ The Civil Code came to garner the main legal provisions applicable to a determined area of life, and in this way, provide legal certainty, stability, ${ }^{273}$ and facility of consultation through legislative

\footnotetext{
267 Xavier Blanc-Jouvan, Worldwide Influence of THE French Crvil COde of 1804, ON THE OCCASION OF ITS BICENTENNIAL CELEBRATION 2 (2007), available at http://scholarship.law.c ornell.edu/cgi/viewcontent.cgi?article $=1003 \&$ context=biss_papers (alluding to "two centuries of legislative additions and amendments" to the French Civil Code of 1804).

${ }_{268}$ Lobingier, supra note 101, at 114 (mentioning the simplicity of access to the law by every citizen as a revolutionary goal).

${ }^{269}$ JAKSIĆ, supra note 6, at 170-74 (reviewing "the Roman Law Foundations of the [Chilean] Civil Code"); see also Knütel, supra note 141, at 2 ("Por medio, especialmente de los códigos europeos, y sobre todo del francés, se han difundido estas normas, y con ellas el Derecho Romano, en todo el mundo.") ("Especially through the European codes, and above all the French Code, these provisions have been disseminated, and with them the Roman Law, throughout the whole world." (author's translation)).

270 Paul Berry, Outline History of Rome: From the Earliest Record (753 B.C.) To THE CODE OF JUSTINIAN (A.D. 534) 358 (2006) ("The Code of Justinian was enacted in 534.").

271 Id. at 398.

${ }^{272} I d$. at $367,419-23$.

${ }^{273}$ Id. at 419 ("[L]a promulgation des codes constitua pour beaucoup des jeunes États cherchant à former leur unité politique, le moyen de renforcer leur cohesión, et d'assurer la stabilité juridique recherchée.") ("The promulgation of codes constituted, for many of the new States seeking to form their political unity, a means to strengthen their cohesion, and to
} 
coherence. ${ }^{274}$ The Civil Code became the lege ferenda, the new law that would govern the polis from that time onwards, in a centralized manner. ${ }^{275}$

It is hardly disputed that the Civil Code was designed to be a means to greatly expand the governmental control of society. ${ }^{276}$ The Civil Code became the primary means of implementing the principles of codification and unification of the law proclaimed in Title I of the Revolutionary Constitution of $1791 .{ }^{277}$ Alongside the 1791 Constitution, the "Law on the Gathering of Civil Laws in One Body, Under the Title 'Code Civil des Français," already referenced, proscribed in Article 7 that: "commencing on the day these laws enter into effect, the Roman laws, ordinances, general or local customs, statutes [and] regulations cease to have the force of a general or particular law in the matters which are the subject of those laws composing the present Code."278 With Napoléon carrying the banner, the authors of the Civil Code believed that they were following the steps of Justinian, and that by replacing all pre-existing laws, the Civil Code "was suitable to govern the legal affairs of all nations at all times by dint of its rational content."279 Thus, the pretense of universality, broad government control, and state authoritarianism were clearly stated at the very onset of the revolutionary legal efforts.

The Civil Code of 1804 was followed by the Code of Civil Procedure of 1806, replaced in 1976; the Code of Commerce of 1807 and then the Code of Criminal Procedure of 1808, replaced in 1958; and the Penal Code of 1810 , replaced in 1994.

In Latin America, the Chilean Civil Code represented the model of civil legislation after the independence movement, and was utilized as an instrument to achieve the purported goal of social cohesion. ${ }^{280}$ Further reforms of the new legal systems came to fully rely on the philosophy, strength, and reach of the Civil Code. The contrast with the common law's

achieve the legal stability sought." (author's translation))

274 BASDEVANT-GAUDEMET \& GAUDEMET, supra note 51, at 359.

${ }^{275}$ Lobingier, supra note 101 , at 115 (commenting that codification required a centralized power).

276 VAN CAENEGEM, supra note 21, at 125 ("Sovereigns regarded the promulgation of national codes as an essential component of their policies of unification.")

2771971 CONST. Tit. I (Fr.), available at http://sourcebook.fsc.edu/history/constitutionofl 79 1.html ("A code of civil law common to the entire kingdom shall be drafted.").

278 Author's translation.

${ }^{279}$ WATKIN, supra note 106 , at 450.

${ }^{280}$ A prominent politician wrote to Andrés Bello à propos Bello's draft civil code for Chile "[W]e must take advantage of the wisdom of other countries, and especially the legal doctrines of our South America. This might well represent a first step toward the desired social unity of our continent." JAKSIĆ, supra note 6, at 174. 
approach to legislation is evident. ${ }^{281}$ Thus, in the case of Chile, the Civil Code of 1855 crowned itself as the true "pillar of the centralized state and established the basis from which more radical innovations would be introduced in the future, especially the anticlerical legislation of the 1880s." 282

The revolutionary French Constitution of 1791 clearly conceived the Civil Code as a tool for tight government control of society. Latin America, in accordance with that stated goal, followed the Revolution in due course, and for two hundred years has lived under the canopy of the French Civil Code of $1804{ }^{283}$

\section{PROMOTION OF A DYSFUNCTIONAL SYSTEM OF CRIMINAL LAW AND PROCEDURE}

The dysfunctionality of Latin American criminal law and procedure systems has been largely attributed to their inquisitorial character. Three hundred or more years of Iberian inquisitorial law and procedures in the Latin American colonies are said to have paved the way for a profoundly inhuman criminal system. To prove the influence of inquisitorial law and procedure on Latin American legal systems, frequent mention is made, for instance, to the Santo Oficio (Holy Inquisition), which was not abolished formally in Colombia until the Constitution of $1821 .{ }^{284}$

Oddly enough, colonial inquisitorial procedures were not different qua processus from criminal procedures instituted against persons charged with non-religious crimes. ${ }^{285}$ In fact, inquisitorial procedures signified a great advance in the temporal human quest for humane criminal justice. ${ }^{286}$ In fact, the Roman system, which was exclusively accusatorial, required the accuser

281 See E. Allan Farnsworth, A Common Lawyer's View of His Civilian Colleagues, 57 LA. L. REV. 227, 232 (1996) (referring to the "common lawyer's mistrust of legislation").

282 JAKSIĆ, supra note 6 , at 181.

283 BLANC-JouVAN, supra note 267, at 3 (referring to the "solid positions that our Code [the French Civil Code of 1804] retains in many countries, even those which want to take some distance from it. Among many examples ... in Latin America").

284 Nagle, supra note 166, at 352.

285 Henry A. Kelly, Inquisition and Other Trial Procedures in the Medieval West 443 (2001) ("There was not a single provision of the original ordo juris or rules of procedure for inquisition that privileged heresy cases over all other kinds of cases or limited due process for persons charged with heresy in ways that were not permitted for persons charged with other crimes.").

${ }^{286} I d$. at 480 ("In conclusion, inquisition was a brilliant and much-needed innovation in trial procedure, instituted by the greatest lawyer-pope of the Middle Ages [Pope Innocent III]. It served the generality of church courts very well and formed the basis of modern Continental criminal procedure."). 
to bear the penalties carried by the crime denounced, in case he failed to prove his accusation. ${ }^{287}$ Canonical law added two other kinds of criminal procedures: the denunciation, and the inquisition, which were meant to act as "substitutes for accusation." 288 The traditional criminal and civil procedures in the West were, in fact, accusatorial up to the time of the French Revolution. ${ }^{289}$ Trials consisted "of a contest between a plaintiff or accuser and a defendant, with the judge acting as moderator., 290

The inquisitorial procedure represented a true humanization of the ancient Roman criminal procedure from the system of private vengeance. ${ }^{291}$ These developments included the fact that the accuser would summon the accused and explain the charges brought against him; that the accused enjoyed a right to remain silent; that his guilt or innocence was to be determined in a decision based on evidence legally proffered before the court; and that he had a broad right to appeal unfavorable decisions at any stage of the proceedings. ${ }^{292}$ Such developments embodied a progress without precedent in human history.

Many of today's criminal procedural guarantees were created by canonical law and drawn expressly and directly from biblical sources. ${ }^{293}$ For instance, the Miranda right to remain silent when facing an arrest tracks its origin to the medieval inquisitorial right to silence, specifically "deduced from the canonical rules of due process." ${ }^{, 294}$ The same occurs with the defendant's right to receive a detailed explanation of the charges brought against him by a judge in a legally-ordained procedure. ${ }^{295}$ Human abuses in the form of blatant departures from established inquisitorial procedures undeniably took place, but even in those cases, prominent inquisitors did their best to correct such abuses. ${ }^{296}$

The Revolution seems to have looked at the available procedures under the ancient regime (accusatio-accusation; denunciatio-denunciation; and inquisitio-inquisition), and concluded that the latter fit squarely with the

\footnotetext{
287 Id. at 407.

288 Id. at 995.

289 MerRyMAN \& PÉREZ-Perdomo, supra note 69, at 128 (commenting that the Spanish Siete Partidas describes the criminal system as accusatorial).

${ }^{290}$ KELLY, supra note 285 , at 409.

291 MERRYMAN \& PÉREZ-PERDOMO, supra note 69, at 128.

${ }^{292}$ KeLLY, supra note 285 , at 2 (elaborating further in the chapter titled "Trial Procedures against Wyclif and Wycliffites in England and at the Council of Constance").

293 Id. at 995.

${ }^{294}$ Id. at 992.

295 Id. at 995.

${ }^{296}$ See id. at 999 (commenting on the correctional efforts of the great Spanish Inquisitor, Tomás de Torquemada).
} 
revolutionary concept of an omnipotent State, which recognized no other authority or sovereign superior to itself. ${ }^{297}$

A series of connections exist, therefore, between French revolutionary ideas and the "sorry state of criminal law" in Latin America starting in the early nineteenth century. ${ }^{298}$ A broad review of the criminal law reforms that took place after 1789 is necessary to track the monumental influence of the revolutionary agenda upon the nascent Latin American criminal systems. ${ }^{299}$

One of the priorities of the revolutionary program was the overall restructuring of the criminal system. ${ }^{300}$ This program comprehended the main aspects reviewed below.

First, revolutionary criminal law and procedure drew extensively from Cesare Beccaria, ${ }^{301}$ to date, the most influential author on criminal law in the West. ${ }^{302}$ In his blueprint work, On Crimes and Punishments, of 1764, Beccaria states: "[J]udges in criminal cases have no right to interpret the penal laws, because they are not legislators. Once the codes of laws are fixed, they should be observed in the literal sense and nothing more is left to the judge than to determine whether an action be or be not conformable to the written law." ${ }^{303}$ The revolutionaries sided with Beccaria's enlightened approach to the judicial function and, accordingly, institutionalized the judges' handicapped status as minor servants of the revolutionary justice machinery. ${ }^{304}$ However, since it was not possible for the French Revolution to get rid of criminal judges altogether, it maintained them at the lowest level of the government, subject to the will of the majority as represented by the legislature. $^{305}$

${ }^{297}$ Rogoff, supra note 65 , at 23 (alluding to the "Code of private law in France [which is based on] the principles of legislative supremacy").

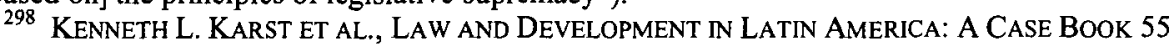
(1975) ("[M]uch of this penal law was barbaric and outdated.").

${ }^{299}$ MERRYMAN \& PÉrEZ-PERDOMO, supra note 69, at 125 (referring to the "sorry state of criminal law and procedure").

300 BasdeVAnt-GaudemET \& GaUdemet, supra note 51 , at 331.

${ }^{301}$ MerRYMAN ET AL., supra note 92, at 1060-63 (commenting on the influence of Beccaria on the criminal reforms implemented in the aftermath of the Revolution, particularly the principle of nullum crimen sine lege and nulla poena sine lege [crimes and punishment can only be determined by statutory law]).

302 Merryman \& PÉrez-Perdomo, supra note 69, at 125 (commenting on the strong influence of Beccaria's works throughout Europe during the eighteenth and nineteenth centuries).

${ }^{303}$ Cesare Beccaria, On Crimes and Punishments 12 (1764). Also cited in Merryman ET AL., supra note 92, at 1061 .

${ }^{304}$ Farer, supra note 34 (describing judges as "only a certain species of bureaucrat").

${ }^{305}$ Haley, supra note 255 , at 85 (analyzing the lingering risks of having "an absolutely independent judiciary"). 
Abundant information and scholarly work throughout generations show that the handcuffing of criminal judges in Latin America has cooperated extensively to the ruin of criminal procedures in the region, and perpetuated the sorry state of things. ${ }^{306}$ In contrast to the revolutionary ideal, minimal legal and logical thinking are sufficient to surmise that judges do, in reality, interpret criminal laws. To deny judges this essential attribute is tantamount to cripple the lame man twice. And this is what has happened in Latin America, thanks to the French Revolution.

Second, the French Revolution obliterated the presumption of innocence. The Revolution's initial overall goal of ridding society from-what they considered to be--the shackles of religion ${ }^{307}$ included an active contempt toward all things emanating from the Judeo-Christian concept of justice and guilt. ${ }^{308}$ In particular, the Enlightenment rejected those concepts of justice and guilt embodied in canonical law. The rebuff of religious law by the Revolution included the presumption of innocence, which was a notion omnipresent in and greatly familiar to the pre-revolutionary ius commune of Europe. $^{309}$

Third, the imposition of harsh criminal laws discouraging crime fit perfectly with the Robespierrean attachment to "guillotine justice" and the Beccarian exhortation to apply severe punishment to criminals. ${ }^{310}$ The aristocratic revolutionaries sought to protect themselves from the undesirables, and harsh criminal punishment was thought to be conducive to that effect. ${ }^{31}$ As a matter of criminal policy, the Revolution was more concerned with the preservation of the public order than with the rehabilitation of criminals. ${ }^{312}$ Crowded Latin American jails, in effect, bear witness to the harsh punishments inflicted on poverty-arisen crime. ${ }^{313}$

\footnotetext{
306 KARST ET AL., supra note 298, at 91 (describing the Latin American judge as "a kind of expert clerk").

${ }_{307}$ Neuhaus, supra note 53, at 86 (discussing the dogma of the secular Enlightenment proposing that "as people become more enlightened (educated), religion will wither away").

${ }^{308}$ See Sirach 11:7 ("Before investigating find no fault. Examine first then criticize.").

${ }^{309}$ KELLY, supra note 285 , at 444 ("I dismiss without further ado the modern notion that defendants in any canonical process, inquisitorial or not, were presumed guilty until proven innocent. No one could be legally convicted of a crime without adequate proof.").

${ }^{310}$ See BECCARIA, supra note 303, at 40 (commenting than the sentence of slavery is more severe and a greater deterrent than death).

311 Id.

312 BASDEVANT-Gaudemet \& Gaudemet, supra note 51, at 397 ("Il faut punir pour assurer la tranquillité publique.") ("It is necessary to punish to ensure public tranquility." (author's translation)).

${ }^{313}$ ChARLES DE SECONDAT, supra note 73, at 187 (describing the use of the death penalty as "the remedy, as it were, of a sick society").
} 
Fourth, the Revolution eliminated the criminal defendant's obligation to testify under oath on behalf of his own persona. ${ }^{314}$ This is certainly a controversial matter where religion and law, in their raw expressions, either collide or collaborate. In other words, the very origin of the concept of an oath is religious, and goes back to the Ten Commandments. Legal systems in the West built the procedural notion of oath based on the sacredness of the Judeo-Christian concept of oath. ${ }^{315}$ Therefore, the exigibility of an oath in a civil or criminal procedure, and the attached consequences for its violations do trace their origins to religion. An oath is the invocation of the sacred to back-up-or bring as a witness to-one's own testimony and may only be understood in the realm of the spiritual. ${ }^{316}$ The Commandment to not invoke the Lord's name in vain carries the implicit consequence of punishment in the afterlife in case of perjury. ${ }^{317}$ Since almost all Europeans were believers when the legal systems of the West were formed, either in the Christianized Roman law, or the subsequent ius commune, ${ }^{318}$ it was a natural step for those legal systems to incorporate a mandatory oath in their civil and criminal procedures. If the deponent was willing to take an oath in Church, he was even more prepared to take such oath in secular procedures, where available punishments affected the body, not the soul.

As stated, the French Revolution, keen to its secular spirit, eliminated the sacredness of the oath. ${ }^{319}$ It "laicized" the oath in the sense that it still compelled the criminal defendant to testify, but it eliminated the requirement

314 Karl Ludwig von Bar et al., A History of Continental Criminal LaW 319 (1999) (referring to the constitutional reforms undertaken by the French Constitutional Assembly of 1789 , which included, "6th, abolition of the accused's compulsory oath").

315 Exodus 20:7 ("You shall not take the name of the LORD your God in vain.").

316 Id.

317 Id. ("[F]or the LORD will not hold him guiltless who takes his name in vain.").

318 JAKSIC, supra note 6, at 172 ("[E]specially in [Spanish American] countries whose civil legislation is but a manifestation, indeed a copy, of Roman legislation."); id. at 174 ("With the exception of short-lived experiments in adopting the French civil code in Oaxaca (1827), Bolivia (1831), and Costa Rica (1841), most Spanish American countries continued to make do with the existing legislation. They were caught in the same dilemma of how to retain embedded legal traditions while adapting them to new republican political arrangements. Bello's careful balance between the two, combined with a consistent reference to Roman law, immediately captured the attention of other countries. From Colombia, Manuel Ancízar wrote to Bello on July $10,1856, \ldots$ 'This might well represent a first step toward the desired social unity of our continent.' "). Concerning the influence of Bello's Civil Code on other Latin American countries, see id. at 175-76 ("There is no doubt that Bello followed Roman law in the preparation of the Civil Code.").

${ }_{319} 1791$ CONST. tit. II, paras. 2, 4 (Fr.) (regulating the "civic oath" taken by private citizens in the context of naturalization procedures); $i d$. para. 5 (describing the civic oath as follows: "I swear to be faithful to the nation, to the law, and to the King, and to maintain with all my power the Constitution of the kingdom...."). Numerous other provisions refer to the civic oath taken by public officials. Id. 
that he do so under oath. A simple promise to tell the truth was not required anymore, and the violation thereof did not constitute grounds for further prosecution for perjury in the case of the accused.

Common law went a step beyond this evolution and eliminated the defendant's obligation to testify under oath altogether, with the addition that no inferences be drawn from the defendant's reluctance to testify. ${ }^{320}$ This election has deprived the trier of fact in common law of an important evidentiary means to establish the truth. This "negative" guarantee opens the possibilities for the guilty defendant to walk away unpunished, and thus paves the way for the mockery of the judicial criminal system. In that sense, the civil law system requiring all criminal defendants to testify under promise, without the threat of perjury, curbs the extreme risks of the common law. Such compulsion is slightly more in accordance with human reason and the ontological goal of all criminal procedures, the establishment of the truth.

Returning to the revolutionary influence in Latin American criminal procedures, these jurisdictions followed suit and eliminated the defendant's obligation to provide compulsory testimony under oath. ${ }^{321}$ However, the revolutionary approximation overlooked the core rational aspects of the compulsory oath. If the defendant is innocent, his testimony will help to establish the truth. ${ }^{322}$ No exposition to perjury occurs and justice is served. And justice being, allegedly, the ultimate goal of the whole legal apparatus, it may be fairly said that "malum quidem nullum esse sine aliquo bono." 323 if the accused is guilty, bearing in mind that he has already committed a crime (the underlying wrongdoing for which he is being prosecuted), the rationale was that he would have no obstacle in committing another crime (perjury) to get away from secular punishment. This rationale is insufficient in the sense that when the guilty defendant is compelled to testify under oath and commits perjury, it is not the end of the story. His confession must be

\footnotetext{
${ }^{320}$ For a discussion of the general differences between common law and civil law, see MERRYMAN ET AL., supra note 92, at 27-50.

321 See, e.g., Código de Procedimiento Penal [Cod. CRim. Proced.] art. 320 (Chile) ("La declaración del inculpado no podrá recibirse bajo juramento.") ("The testimony of the accused may not be received under oath." (author's translation)).

322 Elisabetta Grande, Dances of Justice: Tango and Rumba in Comparative Criminal Procedure, 9 Global JURIST 4, 8 (2009), available at http://www.bepress.com/gj/vol9/iss4/ art6/ (observing the Protestant influence in the common law adversarial criminal procedure, according to which no objective truth exists that needs to be discovered by the trier of fact, but whatever notion of truth the parties reach).

${ }^{323}$ "There is, to be sure, no evil without something good." Pliny the Elder, Latin Quotes and Latin Phrases - M\&N, YUNI, http://www.yuni.com/library/latin_4.html (last visited Nov. 20, 2010).
} 
contrasted with other evidence for the threshold, at least in common law, of guilt beyond reasonable doubt, to be fulfilled. ${ }^{324}$

In summary, the criminal defendant's testimony is, by itself, just another means of evidence that is not self-sufficient for purposes of the procedural determination of guilt or innocence. Additional evidence is necessary to effectuate a determination. The defendant's testimony is relevant to determine the facts of a case and thus the truth of the underlying events, ${ }^{325}$ in order to achieve justice, whether criminal or civil. This system was never meant to serve, and never a means to cause, a self-incriminatory oath. ${ }^{326}$ The revolutionary elimination of the compulsory oath in criminal procedures did not help to further the search for justice in such procedures. Contrary to these arguments, there is no reason not to have (even if by force) the defendant testify without requiring him to take an oath.

What the revolutionary ideologues apparently sought was lenience, especially for criminal defendants, by not exposing them to perjury by testifying under oath. The implicit caveat was that the defendant might do so voluntarily at any moment. Furthermore, revolutionary criminal law ideas never distinguished between the concealment of the truth from the outright making of false statements. ${ }^{327}$ The new concept of procedural justice failed to make this distinction, which was instrumental in the shaping of criminal procedure codes in Latin America as well. ${ }^{328}$

Still, the argument lingers that, by not requiring criminal defendants to testify under oath, the revolutionary lenience showed more humanity toward the natural tendency of the human soul to lie in self-defense. Even if, arguendo, the benefit of the doubt was given to these revolutionary "ideals," multiple evils are brought about by revolutionary "laicization" of the compulsory oath. Therefore, because the French Revolution eliminated the millenary mandatory oath in criminal procedures in the Western legal systems, many of the guilty have walked away unpunished, many of the innocent have been wrongly punished, and many victims have been deprived of their day in court.

\footnotetext{
${ }^{324}$ See generally James Q. Whitman, The Origins of Reasonable Doubt: Theological RoOTS OF THE CRIMINAL TRIAL 4 (2008) (referring to the Christian law principle extant since the Middle Ages stated as "A judge who is in doubt must refuse to judge.").

${ }^{325}$ Grande, supra note 322 , at 2 (referring to the role of the criminal procedure in the determination of an ontological truth).

${ }^{326}$ KELLY, supra note 285, at 1005 .

327 KARST ET AL., supra note 298 , at 55 ("Here, too, the liberalizing, rationalizing, and modernizing influence of the French Revolution and the Napoleonic Penal Code of 1810 was plainly reflected in Latin American codification.").

${ }^{328} I d$.
} 
Lastly, through the Chapelier Law of 1791, the Revolution eliminated the right to self-defense; that is, the right of the accused to be defended by legal counsel. ${ }^{329}$ The belief was that the modern man was self-sufficient and capable of defending himself without the need to resort to the assistance of a discredited profession: the advocates. ${ }^{330}$ In this way, the Revolution did away with a quintessential Romano-Canonical institution, i.e., the right to counsel, that even inquisitorial procedures respected and promoted. ${ }^{331}$ In sum, the denegation of the accused's right to counsel so often included in the indictments of Latin criminal procedures by common law commentators, ${ }^{332}$ is actually a legacy of the French Revolution to Latin America, and not a progeny of the Spanish legal legacy. ${ }^{333}$

\section{A CIVIL PRocEDURE MESHED WITH RIGIDITIES AND INCONSISTENCIES}

The revolutionary authoritarianism also made its influence felt in the realm of civil procedure. Emphasis was placed on governmental control of the different phases of the procedure: pleadings, gathering and production of evidence, weighing of the proof by the trier of fact, and multiple other processual junctures. ${ }^{334}$ Stiff statutory standards were imposed on judges for the review of evidence. Judicial discretion was greatly curtailed; in effect, contempt powers, equitable powers, and other related measures were visibly denied to the judiciary. ${ }^{335}$

\footnotetext{
329 See infra note 447.

330 Levasseur, supra note 108, at 771 (mentioning the French Revolution's view that "citizens [are able] to defend themselves").

331 KeLLY, supra note 285 , at 445 ("Persons accused of heresy had a right to be defended by legal counsel, just like persons accused of other crimes.... If one wants to find a legal system in which persons who were only charged with a felony were denied a trial lawyer, one can look to the English common law. This infringement of the defendant's rights was eliminated only in 1836.").

332 MERRYMAN ET AL., supra note 92, at 1063 (commenting that in inquisitorial criminal trials in civil law countries "the accused had no right to counsel").

${ }^{333}$ Carlos Rodrigo de la Barra Cousino, Adversarial vs. Inquisitorial Systems: The Rule of Law and Prospects for Criminal Procedure Reform in Chile, 5 Sw. J.L. \& TRADE AM. 323, 324-25 (1998) (describing the pains through which Chile has gone through to overcome the imperfections of its traditional criminal law procedure system). In the same vein, see generally Rafael Blanco et al., Reform to the Criminal Justice System in Chile: Evaluation and Challenges, 2 LOY. U. CHI. INT'L L. REv. 253 (2005) (describing the process of judicial reform in Chile). Alternatively: RECOPILACION DE LEYES DE LOS REYNOS DE LAS INDIAS [COMPILATION OF THE LAWS OF THE KINGDOMS OF THE INDIES] 255-58 (1774) (regulating the multiple aspects related to the right of defense of parties, and the duties of lawyers toward their clients in Spanish America).

334 See MERr YMAN \& PÉREZ-PERdomo, supra note 69.

${ }^{335}$ For a more detailed comparison of civil procedure in civil and common law systems, see APPLE \& DEYLING, supra note 3, at 26-31.
} 
A comparison is often drawn between the active role of the parties in common law procedures and their passive role in civil law systems. ${ }^{336}$ While there is some truth to this observation, the caveat is that the active role of the judge in Latin American civil procedures, in general, is a subordinated one. The latitude granted to the judge to intervene in the civil procedure has been already pre-determined in the law. Therefore, control of the civil procedure rests with the legislature and not the judges. If at first glance it appears that the judicial control of civil is conducive to the establishment of truth, the real mediate control is in the hands of the legislator.

Certain specific aspects of the revolutionary legal legacy on Latin American civil procedures deserve a more detailed review. First, as discussed above, the French Revolution rejected the use of mandatory sworn testimony in civil and criminal procedures, instituting the decisory oath instead. The typical decisory oath in Latin American civil procedures occurs when one party is summonsed to a special hearing where a sealed envelope containing a series of interrogative or affirmative questions prepared by the other party is opened, to which the summoned party must respond under oath. If the summoned party attends and readily admits the facts presented in the pre-set questions, the facts are taken as conclusively proven against that party. The same occurs if the summoned party refuses to attend the hearing with respect to the questions stated in the affirmative. ${ }^{337}$ Thus, the harshness attached to the refusal to appear to respond to these questions is a consequence of the removal of the mandatory oath in civil procedure by the Revolution.

Second, the disqualification of certain persons from providing testimony has deprived civil procedures from an important tool in determining the facts

\footnotetext{
${ }^{336}$ For a comparison of civil and common law systems, see Jean Louis Bergel, Principal Features and Methods of Codification, 48 LA. L. REV. 1073 (1988); Joseph Dainow, The Civil Law and the Common Law: Some Points of Comparison, 15 AM. J. COMP. LAW 419 (1966);

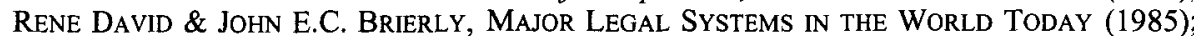

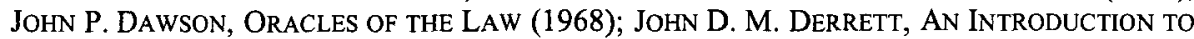
LEGAL Systems (William M. Gordon \& Olivia F. Robinson trans., 1988); Konstantinos D. Kerameus, A Civilian Lawyer Looks at Common-Law Procedure, 47 LA. L. Rev. 493 (1987); Hein Kotz, Taking Civil Codes Less Seriously, 50 MoD. L. REV. 1 (1987); MERRYMAN \& PÉrez-PERDOMO, supra note 69; JoHN H. MERRYMAN \& David S. Clark, Comparative LAW: WESTERN EUROPEAN AND LATIN AMERICAN LEGAL SYSTEMS (1976); OliviA F. ROBINSON ET AL., AN INTRODUCTION TO EUROPEAN LEGAL HISTORY (2d ed. 1987); MARTIN M. Shapiro, Courts: A COMParative and Political ANalysis (1981); ARThur T. VON MEHREN, LaW IN THE UNITED STATES: A GeNERAL AND CoMparative VIEW (1988); ARTHUR T. VON MEHREN \& JAMES R. GORDLEY, THE CIVIL LAW SYSTEM (2d ed. 1977).

${ }^{337}$ See generally MERRYMAN \& PÉREZ-PERDOMO, supra note 69, at 119 (describing weight given to different types of testimony); see also GOLBERT \& NUN, supra note 155, at 24 (mentioning that "[b]esides stating the pleadings or defenses and exceptions with which the defendant intends to oppose the action, the answer may include affirmative defenses").
} 
during the evidence-gathering stages. These disqualifications existed prior to 1789, but the French Revolution did nothing to overhaul them. ${ }^{338}$

Third, the evaluation of the evidence by the trier of fact is subject to stiff established statutory rules. ${ }^{339}$ These guidelines provide scarce latitude to the judicial appreciation of the evidence. The so-called system of "legal proof" consists of a set of mechanical rules that pre-determine the value that the judge is forced to assign to the evidence at hand. ${ }^{340}$ This arrangement greatly reduces the judicial discretion required for adjudication.

Fourth, the open-ended right of the parties to file direct appeals and interlocutory appeals in all of the stages of Latin American judicial process has caused a paralysis of adjudicatory activities. In fact, since the Revolutionary model was based on a deep distrust for the judicial role, broad rights to further hearings before higher courts were granted to litigants. ${ }^{341}$ Ensuing interminable lawsuits have been the general rule in civil adjudication in the region.

Fifth, lack of stare decisis has caused great docket congestions in Latin American courts. Consider, for example, that thousands of cases are filed every year at the supreme tribunal of Brazil ${ }^{342}$ on topics already decided by that court. Contrast these figures with the number of cases accepted by the U.S. Supreme Court via certiorari in a given period. ${ }^{343}$ These huge court

\footnotetext{
338 See French Code of Civil Procedure of 1806, art. 283 (Chez J.P. Giegler ed., 1806) (detailing the disqualification of certain persons to serve as witnesses).

${ }^{339}$ MerRyman \& PÉREZ-PERDOMo, supra note 69, at 118 (discussing the Medieval system of "legal proof," whereby all of the evidentiary means and their procedural weight are determined by the law).

340 Id. at 120 .

${ }^{341}$ C.H. van Rhee, The Influence of the French Code de Procédure Civile (I806) in 19th Century Europe," in De LA COMMÉMORATION D'UN CODE À L'AUTRE: 200 ANS DE PROCÉDURE CiviLE EN FrANCE 129-65 (L. Cadiet \& G. Canivet eds., 2006), available at http://arno.unima as.nl/show.cgi?fid=7053 (referring the broad availability of appellate review in the French Code of Civil Procedure of 1806).

${ }^{342}$ Richard J. Wilson, Reflections on Judicial Review in Latin America, 7 Sw. J.L. \& TRADE AM. 435, 443 (2000) ("The Brazilian Supreme Court decided the same issue over 10,000 times in a single year because of the lack of stare decisis and the mandatory nature of Supreme Court jurisdiction for certain matters."); see also Keith S. Rosenn, Judicial Review in Brazil: Developments Under the 1988 Constitution, 7 Sw. J. L. \& TRADE AM. 291, 291 (2000) (noting the lack of binding precedent in the Brazilian judicial system).

343 Rosenn, supra note 342, at 311-12 (highlighting that the U.S. Supreme Court, during the 1999-2000 term, had only 2,413 cases on its docket and decided 115 cases. Between the 1988 Constitution and 1996, cases filed in Brazilian courts increased from three hundred and fifty thousand, in 1988, to 3.7 million, in 1996. The number of cases for Brazil's highest courts, the Supreme Federal Tribunal and the Superior Tribunal of Justice, had an average of 3,622.5 cases per judge, and 7,830 cases per judge, respectively during the 1988 through 1996 period).
} 
backlogs have generated a great degree of distrust on the part of common citizens toward civil adjudication procedures in Latin America. ${ }^{344}$

Sixth, the litigants' lack of control over the procedures, and the resulting authoritarianism attached to them, has promoted a culture of secrecy in Latin American civil proceedings. The elimination of the pre-1789 civil courtroom and its substitution by closed chambers are responsible, to a great extent, for this development. ${ }^{345}$

Seventh, the judges' lack of contempt powers to compel the parties to comply with their decisions has, in many cases, generated a mockery of the justice system, ${ }^{346}$ and a protracted low esteem toward the judiciary in Latin America. ${ }^{347}$ Unlike common law, the Latin American civil law judge does not have contempt powers allowing him to impose penalties on the spot to those intervening in the proceedings. ${ }^{348}$ The imposition thereof is subject to a different adjudicatory process. ${ }^{349}$ This way, the threat of direct imprisonment or fines does not exist in Latin America. Therefore, the immediacy obtained by the use of broad contempt powers in the dispatching of cases is largely lost due to the prolonged capitis diminutio to which judges have been subjected to in Latin America.

This Article presents but a sample of the patent and latent defects germane to Latin American civil procedures shaped by French Revolution ideas. The new French Code of Civil Procedure of 1986 does away with many of the entrenched flaws, ${ }^{350}$ but the pillars of the French revolutionary civil procedural system still persist in Latin America.

\footnotetext{
${ }^{344}$ See generally Nagle, supra note 166, at 346 (noting the dissatisfaction of Latin American people with the judicial system).

${ }_{345}$ Robert M. Kossick, Jr., Litigation in the United States and Mexico: A Comparative Overview, 31 U. MIAMI INTER-AM. L. REV. 23, 24 (2000) (commenting on the configuration of court chambers in civil law jurisdictions in the context of the ex parte problem).

346 See M.C. Mirow, Latin American Law: A History of Private Law and Institutions IN SPANISH AMERICA 235-38 (2004) (pointing out disregard of the law as a significant problem in Latin America).

${ }_{347}$ MERRYMAN \& Pérez-PERdomo, supra note 69, at 122.

348 MERRYMAN ET AL., supra note 92, at 1021 ("The power to compel the production of documents, business records, and other evidence... is much weaker [in civil law jurisdictions] that it is in common law jurisdictions.... In the civil law, a person who disobeys a lawful order of the court in a civil action may thus be liable to a party for damages ..., but he cannot be punished by the judge ... . By contrast, the common law judge in a civil proceeding can punish for contempt.").

${ }^{349}$ MerRyman \& PÉREZ-PERDomo, supra note 69, at 123 ("'[T] production of documents, business records, and other evidence, power to subject a party's property to inspection are much weaker" in Latin American civil procedures.").

${ }^{350}$ MERRYMAN ET AL., supra note 92, at 1041.
} 


\section{A CIVIL CODE MARRED WITH INCONSISTENCIES AND INSTRUMENTAL TO A NOTION OF SOCIETY THAT BENEFITS THE FEW TO THE DETRIMENT OF THE MANY}

The Civil Code is, in many ways, the brainchild of the Enlightenment and, at the same time, the padlock imposed on the people by the Revolution. The Code is also the product of a philosophical movement that put reason at the center of every societal institution. Conversely, the Code's liberal ideas were unable to totally do away with the traditional values, the embedded culture, and the organization of the society that it came to rule. In that sense, the Code is a blend of positivism and natural law, the former being represented by Roman law and the latter by customary law. In fact, the Code borrowed extensively from Roman law in many areas, including contract law, ${ }^{351}$ property law, testaments, and certain patrimonial aspects of family law. ${ }^{352}$ But it clearly follows customary law, especially the Custom of Paris, in family law, the law of inheritance (with a strong emphasis on the unity of the family and the domestic power of husband and parents), the forced heirship of relatives, the recognition of children born out of wedlock, the administration of wills, and the acquisitive prescription in good faith..$^{353}$

The revolutionary assumption was that if sovereignty resides in the people and that elected representatives exercise sovereignty through legislation, then the works of the legislature are the supreme expression of the sovereign. This proclamation is at the root of the revolutionary homily. Therefore, the Code, with its implicit pretenses of being Table XI of the Mosaic Law, became a crucial tool of the political power for the total domination of society. Conversely, the Code came to recognize that same political power as its supreme lord. From the beginning of the independence movement, the Latin American founding fathers understood that the Civil Code was the most usable and resourceful tool for the political domination of the nascent nations. ${ }^{354}$ Moreover, there were serious efforts in Chile in 1822

\footnotetext{
351 Tunc, supra note 17, at 450 ("The law of contract is clearly designed for a period of liberalism.").

352 CoDE CIVIL [C. CIV.] arts. 1540-1548 (Fr.).

353 See generally Zweigert \& Kötz, supra note 56, at 89 (mentioning Article 2279 of the Code Civil des Français).

354 JAKSIĆ, supra note 6, at 156 ("On July 23, 1822, Supreme Director Bernardo O'Higgins delivered an enthusiastic call for the Chilean Congress to consider the adoption of the French civil code, also known as the Code Napoleon, for the Republic of Chile: 'You know how necessary it is to reform our laws,' he declared, 'let me hope that you will adopt the five celebrated codes [the grands codes], including the civil code, that are so worthy of the wisdom of the times, and that have exposed the barbarism of all previous legislation! Let us forever erase the institutions built under colonialism and eradicate ignorance! Let us proceed with determination and we will triumph over the obstacles." "). Id. at 180 ("Roman law was the
} 
to adopt the French Civil Code wholesale, an initiative that eventually failed. . $^{35}$

In this context, it is worth examining some of the substantive inconsistencies of the French Civil Code, which later passed on to most of Latin America via the Chilean Civil Code.

First, under the Montesquieuan aura, the Civil Code provided that judges were but the "mouthpiece" of the law and were absolutely banned from interpreting it. ${ }^{356}$ In the so-called "French Deviation," the Cour de Cassation was created in 1791 to empower its judges with the authority to annul judicial decisions. ${ }^{357}$ The function of cassation unavoidably implies the power to interpret statutory laws, and to deem judicial decisions contrary to the literal sense, purpose, intent, or scope of a given statutory material, as a ground to nullify those decisions. The contrivance of the Cour de Cassation as a non-judicial body is but a machination to conceal the undeniable, that is, that judges do interpret laws. This defect is very seriously affects the legal interpretation scheme conceived by the Civil Code.

Second, the denial of equitable powers to judges by forcing them to abide completely by acts of the legislature is also blemished with contradictions. Judges were supposed to adjudicate based on the law. If that law did not exist, they were forbidden from creating it. ${ }^{358}$ In that case, they had to resort to the institution of the legislative referral. ${ }^{359}$ An insuperable inconsistency exists here: Article 4 of the Code, ${ }^{360}$ which forces judges to decide cases under severe penalties even if no law exists, is incompatible with the whole etiology of the revolutionary judicial philosophy. ${ }^{361}$

most powerful intellectual weapon available for [the absolutist states'] typical programme of territorial integration and administrative centralism ....”).

${ }_{355} I d$. at 156.

356 PÉreZ-Perdomo \& Friedman, supra note 181, at 12.

3571791 CONST. tit. III, ch. V, art. 19 (Fr.) ("Il y aura pour tout le royaume un seul tribunal de cassation.") ("There shall exist for all the kingdom, only one court of cassation." (author's translation)).

${ }_{358} 1791$ ConST. tit. III, ch. V, art. 3 (Fr.) ("Les tribunaux ne peuvent... s'immiscer dans l'exercice du pouvoir legislative.") ("The courts may not interfere with the exercise of the legislative power." (author's translation)).

${ }_{359}^{35}$ See supra note 223, on the legislative referral (référé législatif).

${ }^{360}$ CODE CIVIL [C. CIV.] art. 4 (Fr.) ("Le juge qui refusera de juger sous prétexte du silence, de l'obscurité ou de l'insuffisance de la loi, pourra être poursuivi comme coupable de déni de justice.") ("The judge that refuses to adjudicate a case under the pretext that there is no law, or that the law is obscure or insufficient, may be prosecuted as guilty of denial of justice." (author's translation)).

${ }_{361}$ See Konrad Zweigert \& Hans-Jürgen Puttfarken, Statutory Interpretation-Civilian Style, 44 TUL. L. REV. 704 (1970), reprinted in CIVIL LAw 259 (Ralf Rogowski ed., 1996) (discussing the French Civil Code's "Inexcusability Rule"). 
Third, the Code's goal of comprehensiveness immediately faced the insurmountable and arch-repeated reality that "the most ingenious legislator could not foresee and determine all the possible problems which might arise." ${ }^{362}$ Namely, the drafters left unregulated many important areas of law, the main example being that of tort law, which is covered by a meager five provisions of the Code. ${ }^{363}$ Despite its pretensions of universality, countless other areas were left unregulated by the Code, including: commercial partnerships, checks and other commercial instruments, warehouses, maritime mortgage, a satisfactory mortgage system ${ }^{364}$ that would allow the detachment of the underlying transaction from the derivative stocks, ${ }^{365}$ an adequate treatment of the law of movables (personalty), a more thorough regulation of associative forms or legal entities, insurance, bankruptcy, product liability, ${ }^{366}$ class actions, ${ }^{367}$ a thorough regulation of vicarious liability, the liability in case of the dependent worker or employee, and multiple other modern types of contracts. ${ }^{368}$ Equally, key equitable theories

362 Zweigert \& Kötz, supra note 56, at 92; see also MERRYMAN ET AL., supra note 92, at 201-02 (quoting an Attomey General of the U.S. who referred to the Code's aim at regulating the whole of individual and social life as overlooking the fact that "no finite wisdom can provide for the infinite and unknown variety and complexity of future cases").

${ }^{363}$ CODE CIVIL [C. CIV.] arts. 1382-1386 (Fr.).

364 Tunc, supra note 17 , at 450.

365 For a review of recent laws concerning securitization operations and secured transactions in Latin America, see generally Richard C. Jordan, Will The Bubble Burst? Some Subprime Lessons for Mexico, Latin America's Leader in Asset Securitization, 42 INT'L LAW. 1181 (2008); Dante Figueroa, Civil Law Trusts in Latin America: Is the Lack of Trusts an Impediment for Expanding Business Opportunities in Latin America?, 24 ARIZ. J. INT'L \& COMP. L. 701 (2007); Francisco Sánchez, Synthesis and Perspectives of Securitization in Chile: Opportunities for Players in the Chilean Securitization Arena, GLOBAL Securitization Guide (2006); Georgette Chapman Poindexter et al, En Ruta Hacia el Desarrollo: The Emerging Secondary Market in Latin America, 34 GEO. WASH. INT'L L. REV. 257 (2002); Erica W. Stump, Securitizations in Latin America, 8 U. MIAMI BUS. L. REV. 195 (2000); Robert M. Kossick, Jr. et al., Structuring Private Equity Transactions in Mexico, 6 NAFTA: L. \& Bus. REV. AM. 105 (2000); Claire A. Hill, Latin American Securitization: The Case of the Disappearing Political Risk, 38 VA. J. INT'L L. 293 (1998); Boris Kozolchyk \& Dale Beck Furnish, The OAS Model Law on Secured Transactions: A Comparative Analysis, 12 Sw. J.L. \& TRADE AM. 235 (2006).

${ }^{366}$ On this topic, see Michael Gordon, Product Liability Claims on Both Sides of the Border, a Panel Discussion, 8 U.S.-MEX. L.J. 123 (2000); John F. Molloy, Miami Conference Summary of Presentations, 20 ARIZ. J. INT'L \& COMP. L. 47 (2003); Jorge Mosset Iturraspe, General Trends in South American Products Liability Law: An Overview, 20 ARIZ. J. INT'L \& COMP. L. 115, 116 (2003).

${ }^{367}$ Kossick, supra note 345 , at 52 ("Class action suits, as they are conceived, defined, and carried out in the United States, are not realized in Mexico.").

${ }^{368}$ See generally BLANC-JOUVAN, supra note 267 , at 8 (discussing the multiple modern contractual forms incorporated to the original French Civil Code of 1804 during the last two hundred years). 
of corporate law existing in common law systems have gone largely ignored by the Code, namely the doctrine of equitable partnership, the piercing corporate veil doctrine, the doctrine holding corporate promoters liable for their actions, the ultra vires theory, and the sham corporation doctrine, ${ }^{369}$ to name but a few.

Fourth, the overall structure of the Code begs logical strictness and rigurosity. For instance, matrimonial property law is regulated in Book one (On the Persons) whereas it should be included together in the institution of marriage. ${ }^{370}$ Tort liability is catalogued as a "mode to acquire property" instead of as a standing alone legal institution. ${ }^{371}$ Precisely this disorganization led the jurist, Planiol, to state that "Book Three [of the Code] is a rag-bag of heterogeneous matters." ${ }^{372}$

Fifth, contrasting with the terminological exactitude of the German Civil Code, one scholar ${ }^{373}$ has identified the sloppiness or lack of precision in the language of many key provisions of the Code. ${ }^{374}$

Sixth, the progressive dismantling of the Civil Code during the last two centuries has created a widespread sense of lack of legal certainty and a consequential disrespect for the law in Latin America. ${ }^{375}$ The combination of the Code's pretension for perennial universality (remember Napoléon's reference to the "eternity" of his Code) with its accompanying inability to foresee the many changes that would come in society, has left the Code in an

${ }^{369}$ For more on these topics, see Stephen Bainbridge, Abolishing Veil Piercing, 26 J. CoRP. L. 479 (2000); Madhavi Sunder, Piercing the Veil, 112 YALE L.J. 1399 (2002); and Peter B. Oh, Veil-Piercing, 89 TEX. L. REV. 81 (2010).

${ }^{370}$ Zweigert \& Kötz, supra note 56, at 94 ("The structure of the Code civil is plainly unsatisfactory.").

${ }^{371} I d$. at 95 .

${ }^{372} \mathrm{Id}$.

373 Id. at 92.

374 Id. at $92-93$ (identifying the following aspects: "(a) [a]ccording to art. 778 of the Code civil, an inheritance may be accepted either 'dans un acte authentique ou prive' or by means of an 'acte qui suppose necessairement son intention d'accepter': here in the same sentence the word 'acte' is used in the sense of 'deed' and in the sense of 'action. ...' [T] 'propiêté' is used in the sense of 'ownership of things ... [art. 544] and in the sense of wealth of all types [Title of Third Book]; (b) according to art. 1147 Code Civil, a person has to pay damages for breach of contract, unless he proves that a 'cause étrangère qui ne peut lui être imputée' was the reason for nonperformance; (c) according to art. 1148 the duty to make compensation ceases in the event of 'force majeure' or 'cas fortuity.' The relationship between [these terms] is never made clear. (d) "[T]he famous formula "en fait des meubles la possession vaut titre..." " [1]t was left to the courts of France to resolve the following questions: Under what conditions is possession a ground of defence to a rei vindicatio? What is meant by 'possession'? Is good faith required? If so, what constitutes good faith, and at what moment of time must it be established?").

375 See generally Mirow, supra note 11, at 186-89 (containing a succinct relation of the elements contributing to the "burying" of the Civil Code in Latin America). 
uncomfortable gap. The Civil Code's prestige of wisdom, stemming from its purported ability to provide solutions to the most imperative challenges in society, has tumbled vis-à-vis its flawed design.

The slow and painful agony of the Civil Code is witnessed in every corner of the world where its influence extended during the past two centuries. For instance, the patria potestas has been gradually eroded, the business capacity of the married woman greatly changed, and her position upon her husband's death improved, ${ }^{376}$ and the distinctions between legitimate children and others obliterated. ${ }^{377}$ Furthermore, one of the pillars of the Code, namely, contractual freedom, has been progressively worn away. ${ }^{378}$ Curiously, the same Leviathan that as supreme lawgiver erected the Code, that is the legislature, is the one that has systematically restricted such liberty. This has been the case of, for instance, the contracts of lease, sale, carriage, employment law, or insurance law, among the many. ${ }^{379}$ The field of strict liability has also been seriously expanded. ${ }^{380}$ Also, in an express recognition of the overtly wrong gagging of the judges, many recent amendments have granted certain limited equity powers to them. ${ }^{381}$

The overall effect has been that the courts have come to fill in the lacunae left by the Code. In France alone, entire areas of law have been subject to judicial creationism. ${ }^{382}$ Failed attempts at reforming the French Civil Code

${ }^{376}$ Id. at 96.
377 For example, the Constitution of El Salvador of 1983, Article 36, states that children born in or out of wedlock and adoptive children have the same rights in front of their parents. This constitutional provision has been ratified by decisions of the Supreme Court of Justice of El Salvador dated 27 November 1991 (Sala de lo Civil de la Corte Suprema de Justicia, San Salvador, Nov. 27, 1991, 9:00 a.m., in XCII Revista Judicial, Corte Suprema de Justicia 832 (Jan.-Dec., 1991), 3 December 1991 (Sala de lo Civil de la Corte Suprema de Justicia, San Salvador, Dec. 3, 1991, 9:00 a.m., in XCII Revista Judicial, Corte Suprema de Justicia 836 (Jan.-Dec., 1991), and 27 February 1992 (Sala de lo Civil de la Corte Suprema de Justicia, San Salvador, Feb. 27, 1992, 1:00 p.m., in XCIII Revista Judicial, Corte Suprema de Justicia 934 (Jan.-Dec., 1992).

${ }^{378}$ For an exponential increase of regulatory law in recent years in two particular Latin American jurisdictions, Brazil and Chile, see Brendan McNallen, Fixing the Leaks in Brazil's Water Law: Encouraging Sound Private Sector Participation Through Legal and Regulatory Reform, 9 GoNZ. J. INT'L L. 147, 193-94 (2005) (concluding that more legislation and regulation in Brazil's public utitilies sectors is necessary for public-private cooperation in infrastructure projects to prosper).

${ }^{379}$ Zweigert \& Kötz, supra note 56, at 96.

380 Phanor James Eder, A Comparative Survey of ANglo-American and LatinAMERICAN LAW 51-54 (1950).

381 Murillo, supra note 138, at 15.

382 See Zweigert \& Kötz, supra note 56, at 97 (referring to the law of the accident compensation; the social protection of workmen and employees, which go far beyond the Civil Code; the doctrine of abuse of rights, including the issuance of injunctions; the applicability of contracts for the benefit of third parties; insurance contracts; the innovation of 
have taken place since its first centennial. ${ }^{383}$ In 1945 a committee was also appointed to produce draft amendments of the Code. ${ }^{384}$ Only piecemeal reforms have gone through, causing the current Code to be nothing more than an inorganic patchwork of un-systematized legislative activity. ${ }^{385}$ For example, the scant five original provisions of 1804 concerning tort liability have been left almost intact in the current version of the Code, as if life had not changed during the intervening two hundred years. ${ }^{386}$

In sum, the subsequent dismantling of the Civil Code in vast areas of societal life, left unregulated by its drafters, has caused great legal uncertainty, insecurity, ${ }^{387}$ and distrust toward the law from Latin American

a general claim based on unjustified enrichment; the design of the tool of astreinte, a legal device akin to the common law contempt power; the prohibition of successive heirship by means of skillfully drafted wills; and the acceptance of paternity claims based on illegitimacy even before statutory amendments to the Code allowed them); see also MERRYMAN ET AL., supra note 92 , at 1021.

${ }^{383}$ Zweigert \& Kötz, supra note 56, at 98 ("In the centenary year of the Code civil, 1904, a committee was set up to reform it ....").

${ }^{384}$ BELL ET AL., supra note 123, at 24 (commenting reformist efforts undertaken in France during the twentieth century).

${ }^{385}$ Zweigert \& Kötz, supra note 56, at 99 (discussing partial legislative amendments to the Code in the areas of "matrimonial property law, the law of adoption, the legal position of illegitimate children, and the rules of incapacity").

${ }^{386}$ CODE CIVIL [C. CIV.] arts. 1382-1386 (Fr.), available at http://www.legifrance.gouv.fr/affi chCode.do?cidTexte=LEGITEXT000006070721. Only Article 1384, concerning vicarious liability, was amended in 2002. The text of the other provisions is the original from 1804 . CODE CIVIL [C. CIV.] art. 1384 (Fr.).

${ }^{387}$ JAKSIĆ, supra note 6 , at 158 :

Posterity will find it hard to believe that, having moved from a monarchic, despotic and semifeudal regime in order to become an almost democratic representative republic with a division of powers, we should have conserved for twenty one years not only the laws of [medieval] Castile, but also the colonial laws. They currently rule over our political, fiscal and civil administration with codes that concentrate omnipotent powers on a monarch whose government and courts sat three thousand leagues away from our land.

Id. quoting the "Oficio del Presidente de la República al Presidente del Senado," which was included in Cámara de Senadores, "Sesión 9, en 11 de Julio de 1831. Presidencia de Don José Ignacio Cienfuegos," in $A G B, I I, 54-55$. Id. at 161 (recalling that Bello "suggested that the old legislation was probably the best foundation for change, and presented the enterprise of codification as incremental rather than radical"). Id. at 166 ("[T]he new written law retained much of the Spanish colonial legislation, but adopted some provisions from other codes. For instance, in the section on persons, a combination of Roman law, canon law, and the French civil code was adopted to classify the status of children as legitimate, natural, and illegitimate. Canon law was followed on the validity of matrimony...."). Id. at 167 ("[F]or instance, the French civil code and the code of Sardinia were followed on the matter of rights of way and the use and distribution of water, for they were seen as the most conducive to enhancing the cultivation of land.... The section on inheritance stayed close to Roman law and the thirteenth-century Spanish Siete Partidas, but softened some of the edges concerning assignments to surviving spouses, and provided various formulas for the distribution of assets 
peoples. All of this has happened, thanks to the French Revolution's legal ideas that were assimilated in the region.

\section{Promotion of the Individual As the MEASURE Of All ThINGS}

The enlightened man, that is, the man of property who had a right to vote, with a high intellectual life, knowledgeable about business and about the world, is the one who won the French Revolution. This highly individualistic character, and to a certain extent with racist overtones, ${ }^{388}$ became the dominant actor in society. The Enlightened individualism had dire consequences in the legal field as it impacted Latin America since the early nineteenth century.

First and foremost, it is necessary to highlight that the Code's reaffirmation and, to a certain degree, sacralization of individual absolute ownership over all types of property, that is, the exultation of private property as inviolable and sacred, ${ }^{389}$ led to the destruction of communal property in Latin America. In fact, the Civil Code of 1804 prohibited communal property by giving all subjects an absolute right to dissolve undivided property. ${ }^{390}$ For this purpose, the Code created a legal action establishing that any joint property may be dissolved by the action brought by any of the undivided holders at any moment. ${ }^{391}$ The result was that, in fact, communal property became prohibited under the Code. ${ }^{392}$ The contrast between the anti-communal property provisions of the first Latin American

between surviving spouses and children. On contracts and obligations, the Chilean code followed some aspects, such as the nullity and rescindment of contracts, of the French civil code. It followed the codes of Sardinia, the Two Sicilies, and the French code again, on contracts and obligations involving minors and natural children. On the manner of choosing among codes in this section, the message stated that 'as a general rule, the code of the [Siete] Partidas and the French civil code have been the guiding lights that we have kept most constantly in view. Where they differ, we have chosen what seemed most adaptable and convenient [to our circumstances]." ").

${ }^{388}$ CHARLES DE SECONDAT, supra note 73, at 238 ("These creatures are all over black, and with such a flat nose that they can scarcely be pitied. It is hardly to be believed that God, who is a wise Being, should place a soul, especially a good soul, in such a black ugly body.").

389 BASDEVANT-GAUDEMET \& GAUDEMET, supra note 51 , at 348.

390 Mary ann Glendon, Comparative Legal Traditions in a Nutshell 16-57 (1999); Mirow, supra note 143, at 321 (referring to the elimination of limits on free alienation, the forced division of property that is owned in common, and the suspension of the division of property by agreements that are valid for only up to five years). On this last point, see CODE CIVIL [C. CIV.] art. 1317 (Fr.) (reaffirming those provisions).

${ }_{391}$ CODE CIVIL [C. CIV.] art. 815 (Fr.) ("Nul ne peut être contraint à demeurer dans l'indivision.") ("Nobody may be forced to hold property in common." (author's translation)).

${ }^{392}$ See, e.g., CóDiGo CIVIL [COD. CIV.] art. 1317 (Chile) (restating the same rule of art. 815 of the French Civil Code). 
civil codes, with the reality of Latin America before these codes were enacted, is paramount. ${ }^{393}$ In the New Indies, the native inhabitants had lived since immemorial times holding certain lands, mainly pastures, but also other lands, in common. ${ }^{394}$ An elucidatory example is the case of ejido lands in Mexico ${ }^{395}$ which have struggled over centuries to survive the harshness of the anti-communal property provisions of the Civil Code. As the Code could not do away with centuries of customary tradition in the colonies, ways were found to circumvent the anti-communal provisions, whether in the form of crafty contracting, or outright corruption. ${ }^{396}$ There is abundant literature arguing that, in Latin America, these tactics aided land accumulation instead of land distribution, ${ }^{397}$ and this happened, thanks in a great part to the French Revolution.

Second, the guilds, those great institutions of the ancien régime, where people gathered according to profession or craft (merchants, peasants, artisans, etc.) ${ }^{398}$ were utterly destroyed by the Revolution. ${ }^{399}$ These organizations provided a safety net for their members and ensured the welfare of every member. Cooperatives were also ruined by the Revolution. ${ }^{400}$ The cooperative and communal spirit was thought to belong

393 See, e.g., María Vázquez, Land Privatization in Mexico: Urbanization, Formation OF REGIONS, AND GLOBALIZATION IN EJIDOS 59 (2004) (describing how the ancestral situation of ejido lands in Mexico was negatively affected by the civil legislation enacted in the Mexican Civil Code).

394 See Mirow, supra note 346, at 11-18, 61-69, 84-94; MERryman \& PÉRez-Perdomo, supra note 69 , at $364-73$.

${ }_{395}$ M.C. Mirow, Latin American Legal History: Some Essential Spanish Terms, 12 LA RAZA L.J. 43 (2001).

${ }^{396}$ Ana MacLean, Rethinking Legal Education in Latin America, 12 L. \& BUS. REV. AM. 503 (2006) ("Throughout Latin America, but specifically in Peru, the legal profession is in crisis. The legal system is inefficient and corrupt, the number of lawyers is extraordinary, and the ones that actually exercise their profession are themselves considered inefficient and corrupt.").

397 See, e.g., Carlos Felipe Jaramillo \& Thomas Kelly, Deforestation and Property RIGHTS IN LATIN AMERICA, available at $\mathrm{http}: / / \mathrm{ibcperu.org/doc/isis/6247.pdf.}$

398 DAwsON, supra note 44, at 203 ("The life of the medieval gild [sic] was a microcosm ... and its intense solidarity made its membership more important in the life of the individual than that of the city itself ...."). Id. at 204 (mentioning that there were guilds of bankers, lawyers, and also of "the less privileged workers"). Id. at 207 (stating that the functions of the guild included "the regulation of work and wages, the giving of assistance to fellow gild-men in sickness or misfortune, and the right to participate in the government of the city"); see also BELLOC, supra note 80, at 159 ("But the guild could and did undertake the common work and share out the benefits of the wealth it produced.").

399 See H.G. Koenigsberger \& ASA BRIGGS, EARLy Modern Europe: 1500-1789, at 310 (1987) (referring to the abolition of guilds by the Enlightenment).

4001791 CONST. pmbl. (Fr.), available at http://sourcebook.fsc.edu/history/constitutionof 17 91.html (" $[\mathrm{N}]$ either jurandes nor corporations of professions, arts, and crafts any longer exist."). 
to the lower classes of society and, as such, was a direct threat to the individual capitalistic spirit, which was the true winner ${ }^{401}$ and owner of the Revolution. In that sense, the Revolution, together with inaugurating a new world era, destroyed a whole way of life. ${ }^{402}$

Third, at the core of the revolutionary spirit, there is a deeply-seated sense of distrust of the masses. ${ }^{403}$ In the case of the United States, for example, Jefferson showed some degree of discomfort after his initial wholehearted endorsement of the Revolution when he saw the slave uprisings in Haiti. This country had been the first Latin American nation to pass its own version of the Code Civil, in 1825.

Fourth, the triumph of individualism was erected to the detriment of the family in the way it had been organized for about fourteen hundred years in Europe prior to $1789 .^{404}$ More on this topic will be reviewed later under Thesis XIX.

\section{L'ORDRE BOURGEOIS: MUCH FOR THE FEW, LITTLE FOR THE MANY}

An author has rightly pointed out that "the original Code Civil was the law-book of the bourgeoisie." 405 The defense of the bourgeois property was a central worry of the revolutionaries. ${ }^{406}$ The Civil Code favored the unrestrained dominion of capitalism in the Western civil law world. ${ }^{407}$ In that sense, both the advantages and the evils of capitalism are intimately linked to it. ${ }^{408}$

\footnotetext{
${ }^{401}$ Basdevant-Gaudemet \& Gaudemet, supra note 51, at 331 ("triomphe de l'individualisme") ("the triumph of individualism" (author's translation)).

${ }^{402}$ For a review of modern alternative forms of business organizations inspired by preFrench Revolution principles and ideas, see Michael Naughton, The Corporation as a Community of Work: Understanding the Firm Within the Catholic Social Tradition, 4 AVE MARIA L. REV. 330 (2006).

${ }^{403}$ ChARLES DE SECONDAT, supra note 73, at 110 ("Democracy has, therefore, two excesses to avoid-the spirit of inequality, which leads to aristocracy or monarchy, and the spirit of extreme equality, which leads to despotic power, as the latter is completed by conquest.").

${ }^{404}$ BASDEVANT-GAUDEMET \& GAUDEMET, supra note 51, at 351 (quoting R. Szramkiewicz, for whom "la famille est tout a la fois cellulle monarquique et cellulle catholique") ("the family is at the same time a monarchical and Catholic cellule" (author's translation)).

${ }^{405}$ Zweigert \& Kötz, supra note 56 , at 95 .

406 BASDEvanT-GaUdemET \& GAUDEMET, supra note 51, at 396 (referring to the Code of Civil Procedure of 1806 as "la défense de la propriété bourgeoise constituait la préoccupation primordiale") ("The primary purpose was the defense of bourgeois property" (author's translation)).

407 VAN CAENEGEM, supra note 21, at 127 ("The law of these modern codifications proved itself to be perfectly adapted to the needs of the capitalist, middle-class economy of the nineteenth century.").

${ }^{408}$ See Keith S. Rosenn, The Success of Constitutionalism in the United States and Its
} 
In Latin America, the philosophy of liberal economy found in the Civil Code a decisive ally and promoter. ${ }^{409}$ When the industrial revolution hit the Western world, it struck Latin America even harder. The new elites threw themselves into the arms of the Civil Code and used it as their shield to protect accumulation and dominance. ${ }^{410}$ For instance, the sepulchral silence of the Code toward anti-competitive and monopolistic practices has been well documented throughout the West. ${ }^{411}$ The civil law idea that price is determined by the free interplay of offer and demand became a big ruse after the French Revolution. The fact is, contractual freedom and the free determination of prices by the interplay of offer and demand are illusory with respect to most vital items in the market. The emergence of the regulatory State in the twentieth century as an antonymic phenomenon to unfettered economic freedom is largely explained by. the idea of extreme individual economic freedom advanced by the Civil Code. ${ }^{412}$

Huge struggles took place about a hundred years ago to drill into the wall of the Civil Code statutory provisions protecting the small entrepreneur from those already established and exerting tight market dominance. ${ }^{413}$ Contracts of adhesion emerged as the legal expression of market imbalances favoring the overwhelming power of a few to the detriment of the many. Regulatory law emerged during the twentieth century in Latin America as a response to the abuses of capitalism in spite of, and against, the philosophy of the Civil Code.

Failure in Latin America: An Explanation, in THE U.S. CONSTITUTION AND THE CONSTITUTIONS OF LATIN AMERICA 70-71 (Kenneth W. Thompson ed., 1991) (commenting on the liberal tradition of France and its relation to the United Stated democratic experiment).

${ }^{409}$ JAKSIĆ, supra note 6, at 173 (remarking that the Civil code "served as a powerful blueprint for social and political arrangements based on both tradition and the exigencies of an emerging liberal economy").

${ }_{410}$ See Jorge L. Esquirol, The Failed Law of Latin America, 56 AM. J. ComP. L. 75, at 15 (2008) (stating that the protection of private property is one of the main elements of the liberal ideology - of which the Napoleonic Civil Code is a crucial landmark-and that part of the solution to Latin American socio-economic problems lies in broadening property opportunities to vast sectors of the population).

${ }^{41}$ See, e.g., The French Banking Act of January 24, 1984, which came to regulate monopolies in the banking industry, available at http://www.banque-france.fr/gb/publications/ telechar/autres_telechar/bankact.pdf; see also, e.g., IGNACIO DE LEÓN, LATIN AMERICAN COMPETITION LAW AND POLICY 10-42 (2001) (analyzing the emergence of a competition culture in Latin American legal systems).

${ }_{412}$ See Belloc, THE SeRVILE STATE 47 (2008) (analyzing the connection between capitalism, pauperism, and enlightened ideas on the economy).

${ }_{43}$ A good example of this struggle is the passage of laws allowing industrial and agricultural pledges without the transfer of possession of the pledged goods to creditors, thus permitting small entrepreneurs and farmers to obtain loans while continuing their productive activities. 
Only decades after the passage of the Civil Code in Latin America new doctrines emerged aimed at moderating the harsh effects of the Code's unrestrained capitalistic philosophy. ${ }^{414}$ These ideas originated in the Catholic Church and took expression in the notion of the social function of property. ${ }^{415}$ Colossal doctrinal battles ensued in Latin America, after 1893 , between Code-worshippers and the proponents of new legal concepts based on the Catholic principle of social justice and the duty to exercise one's rights without affecting the rights of others or the welfare of the masses. ${ }^{416}$

As a consequence of the revolutionary experiment, occasionally the masses in Latin America have placed their faith in extreme experiments such as communism, the ideology that has killed more people than any other political system in the history of humanity ${ }^{417}$ Again, these phenomena have been greatly facilitated by the ideas spread by French Revolution.

\section{Unleashing the IdEa That the SeXual Conduct of the Citizen IS A PURELY PRIVATE MATTER}

When the traditional family is up and running, little room is left for government intervention. In fact, when the nuclear family stumbles and is destroyed, the government's role is aggrandized. Many evils ${ }^{418}$ form the

\footnotetext{
414 See generally Pavel Kalenskí, Trends of Private International Law 58 (1971) (analyzing the connections between the expansion of capitalism and, among other, the French Civil Code).

${ }_{415}$ See Pope Leo XIII, Encyclical LetTers Rerum Novarum, No. 46 (1891), available at $\mathrm{http} / /$ www.vatican.va/holy_father/leo_xiii/encyclicals/documents/hf_l-xiii_enc_15051891_re_rum -novarum_en.html (alluding to the need to affirm private property for "as many as possible of the people to become owners"); see also POPE PruS XI, Quadragesimo ANNo, No. 53 (1931),

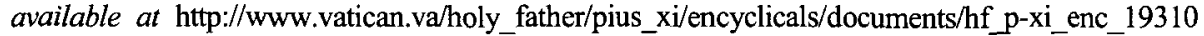
515_quadragesimo-anno_en.html ("[U]nless a man is expending labor on his own property, the labor of one person and the property of another must be associated, for neither can produce anything without the other. Leo XIII certainly had this in mind when he wrote: 'Neither capital can do without labor, nor labor without capital.' "); POPE JoHn PAUL II, CENTESimus ANNUS, No. 30 (1991), available at http://www.vatican.va/holy_father/john_paul_ii/encyclicals/documents/hf_jp-i i_enc_01051991_centesimus-annus_en.html ("Of its nature private property also has a social function which is based on the law of the common purpose of goods.").

${ }^{416}$ TOM BRASS, LATIN AMERICAN PEASANTS 342 (2003) (stating that the "mobilizing discourse used by the Falange in Chile ... was that of Roman Catholicism, and in particular the social teachings contained in the papal encyclicals Rerum Novarum and Quadragesimo Anno, both of which upheld the rights of private property and were against socialism and class struggle").

${ }_{417}$ See generally Benjamin A. VAlentino, Final Solutions: Mass Killing AND Genocide IN THE TWENTIETH CENTURY 91 (2005) ("Communist violence in these three states aloneSoviet Union, China, and Cambodia - may account for between 21 million and 70 million deaths.").

${ }^{418}$ Evils, including: adultery, divorce, incest, sodomy, children born out of wedlock, sexual
} 
breeding ground for an increase of the government's intrusion into the traditional family setting, which has been based, in the West, on the JudeoChristian concept of human sexuality. The breadth of these topics largely exceed the purpose of this Article, but these points show the enormously nefarious effect of the revolutionary ideas in family law throughout Latin America. When the aforementioned blights or a combination occurs, the government emerges as the necessary savior providing welfare services, and a myriad of benefits for the casualties generated by the destruction of the family.

But the government does nothing for free. It also arrogates for itself the power to define institutions that are as natural to man as man is to nature, which is what the revolutionaries of $1789 \mathrm{did}$. The institution of marriage, for example, which was at the root of the pre-Revolutionary social order, was redefined by the revolutionary ideologists. ${ }^{419}$ Marriage evolved from being a concept subject to many vices in pagan times, ${ }^{420}$ to becoming an indissoluble key social institution in 324 A.D. upon the conversion of Rome ${ }^{421}$ to the Church. ${ }^{422}$ By its broad acceptance of divorce, the Revolution transformed marriage into a dissoluble contract, and thus eroded the very foundations of a millenary legal order. Rightly so, marriage has been defined since immemorial times ${ }^{423}$ as the very foundation of the family and of society.

abuse, mistreatment of children, abandonment of children, care for the orphans, for the elderly, homelessness, alimony, pornography, and domestic violence. Tunc, supra note 17, at 447 (" "[T] he door open to divorce is the door open to abuse of divorce." ").

419 Francis Ronsin, Revolutionary Fever and Opposition to Marriage During the "GREAT FRENCH REVOLUTION" (2007), available at http://www.iisg.nl/womhist/ronsin2007. doc (" $[T]$ he text of the Constitution, adopted in August 1791, recognized marriage as a nonreligious contract while remaining silent on divorce. Citizens decided to skip this step. As soon as the Constitution was promulgated they divorced in front of a notary and remarried in front of their municipality."); see also SUzANnE DESAN, THE FAMILY ON TRIAL IN REVOLUTIONARY FRANCE (2006).

${ }^{420}$ Charles De SeCONDAT, supra note 73, at 75 ("At Rome the husband was permitted to lend his wife to another. Plutarch tells us this in express terms.").

${ }^{421}$ Christopher Dawson, The MaKing OF Europe 21 (1946) ("Christianity won the victory-against the Roman Empire-only after a long and bitter struggle."); see also BELLOC, supra note 80, at 25 (affirming that "the conversion of the Roman Empire was a conversion to ... the Catholic Church").

${ }^{422}$ See generally Andrew Alfoldi, The Conversion of Constantine and Pagan Rome 128 (1948) (mentioning the innovations brought about to family law by the Catholic Church within the Roman Empire, including "regulations for divorce, edicts against concubinage, the legitimization of marriage, the encouragament of the will to make gifts, the edicts against the gladiatorial shows").

${ }^{423}$ WATKIN, supra note 106, at 86 (explaining that since the conversion of the Rome, the Church began legislating on matters related to its doctrine, particularly marriage); see also Alan Watson, The MaKing OF THE CIVIL LaW 85 (1981) (citing the Roman Institutes as the source of "that association of man and woman that we call marriage"); SUSAN TREGGIARI, 
Therefore, if marriage is destroyed, the family follows suit, and the logical consequence is to expect an increase in the government's intervention to "remedy" the evils thus befallen society.

In fact, the revolutionaries substituted the notion of consent, as the essential 'rule, for the natural institution of marriage. ${ }^{424}$ In this way, they degraded what, before was considered a universally binding union, into a simple civil contract, ${ }^{425}$ rescindable at will by the parties. ${ }^{426}$ This permissive and relativistic rule obviously transformed the important institution of marriage into a contract to which one can get in or out of, regardless of its consequences. Divorce thus stood at the center of revolutionary family $\mathrm{law}^{427}$ as it fanned out in the West with formidable strength. Marriage dissolubility has accordingly thrown millions into the hands of the Welfare State, or made them totally dependent on charitable institutions.

It is fair to state at this point that, since the most important objective of the Revolution was to preserve the family property and not the institution of marriage, 428 "revolutionary law ruined the very foundations of the family." 429 In sum, this world, as we know it-or rather knew it-has changed dramatically for the worse, and, in good part, thanks to the French Revolution.

\section{ABOLITION OF INHERITANCE SCHEME FaCILITATED DEEP RESENTMENTS AT THE FAMILY AND SOCIETAL LEVELS}

One of the first and foremost principles of the French Revolution was to do away with the core elements of the system of succession of the ancien régime. ${ }^{430}$ The abolition of the inheritance order was de rigueur to consolidate the passing of bourgeois property to the next generation by

Roman Marriage; IUsti Coniuges from the Time of Cicero to the Time of Ulpian 5 (1991) ("Matrimonium is an institution involving a mother, mater. The idea implicit in the word is that a man takes a woman in marriage, in matrimonium ducere, so that he may have children by her.").

${ }_{424} 1791$ CONST. tit. II, para. 7 (Fr.) (“The law considers marriage only as a civil contract.").

${ }^{425}$ CODE CIVIL [C. CIV.] arts. 229-230 (Fr.).

${ }^{426}$ CHARLES DE SECONDAT, supra note 73, at 15 (stating that "the power of divorce can be given only to those who feel the inconveniences of marriage, and who are sensible of the moment when it is for their interest to make them cease").

${ }_{427}$ Id.

${ }^{428}$ See generally Zweigert \& Kötz, supra note 56, at 96 (mentioning the reduced rights over marriage property attributed to the wife as a result of being "unexperienced in business affairs").

${ }^{429}$ BASDEVANT-GAUDEMET \& GAUDEMET, supra note 51, at 353-54 (author's translation).

${ }^{430}$ Lobingier, supra note 101 , at 12 . 
means of instituting testamentary freedom. ${ }^{431}$ The revolutionary legal order considered itself empowered to regulate every aspect of the citizens' lives. The Revolution entrusted the government, that is, the political branch, ${ }^{432}$ with the determination of how this new system of succession would look. In other words, as Montesquieu describes, we inherit not because our parents so decide, but because the government allows it to happen. ${ }^{433}$

The key to the new inheritance scheme was the institution of the legitime, which was a portion of the estate that the testator was free to devise to any of his legitimate heirs, and was equivalent to one-fourth of the estate. ${ }^{434}$ The legitime was aggravated by another device, which was the testator's right to dispose of one-fourth of his estate freely, to anyone, whether or not a legitimate heir. ${ }^{435}$ In toto, the testator was free to devise up to one-half of his estate to any of his legitimate heirs. ${ }^{436}$ Under the Old Regime, the testator did not have that freedom, ${ }^{437}$ and this lack of freedom was considered vital to secure the welfare and unity of the family.

${ }^{431}$ CODE CIVIL [C. CIV.] art. 723 (Fr.) ("[L]a loi règle l'ordre de succéder entre les héritiers légitimes è leur défaut, les biens passent aux enfants naturels, ensuite à l'époux survivant; et s'il n'y en a pas, à la République.") ("The law regulates the order of succession amongst legitimate heirs; if they do not exist, the estate passes to natural children, then to the surviving spouse; and in default of this, to the Republic." (author's translation)).

${ }_{432}$ CHARLES DE SECONDAT, supra note 73, at 62 ("[T] shall provide for their children; but it does not oblige them to make them their heirs. The division of property, the laws of this division, and the succession after the death of the person who has had this division can be regulated only by the community, and consequently by political or civil laws.").

${ }_{433} I d$. at 63 ("A general maxim: it is an obligation of law of nature to provide for our children; but to make them our successors is an obligation of the civil or political law.").

${ }^{434}$ Zweigert \& Kötz, supra note 56, at 96 (called "quotité disponible"); see also BASDEVANT-GAUDEMET \& GAUDEMET, supra note 51, at 386 ("[L]e père dispose librement d'une partie de ses biens, la quotité disponible, pour avantager l'enfant de son choix.") ("The father disposes freely of a part of his property, called 'available quote,' to benefit the child of his election." (author's translation)).

${ }_{435}$ Zweigert \& Kötz, supra note 56, at 96 (called "quotité disponible"); see also BASDEVANT-GAUDEMET \& GAUDEMET, supra note 51 , at 386 (" $[\mathrm{L}] \mathrm{e}$ père dispose librement d'une partie de ses biens, la quotité disponible, pour avantager l'enfant de son choix.") ("The father disposes freely of a part of his property, called 'available quote,' to benefit the child of his election." (author's translation)).

${ }^{436}$ CODE CIVIL [C. CIV.] art. 731-8 (Fr.).

437 JAKSIC, supra note 6, at 169 ("Clearly, the time had not yet come in Chile for the introduction of progressive legislation on matrimony, civil registries, and cemeteries. Bello was also not entirely satisfied with the ultimate outcome of legislation on succession, for he was an advocate of the freedom to designate beneficiaries in wills. Instead, the Chilean code contemplated mandatory assignments, which depended on the number of surviving relatives. Despite these shortcomings, Bello scored major victories in recognizing the rights of children born outside church-sanctioned marriage; removing obstacles for the circulation of property, and abolishing the mayorazgos (entails). The elimination of the latter can be considered a 
The Montesquieuan idea of succession based on an almost absolute freedom of testation strongly impacted Latin America. The extent of this impact is complex and debatable. The institution of the legitime is to blame, in a significant proportion, for widespread quarrels within families. That is, those excluded from the last dispositions of the testator oftentimes have raised suspicions against those benefited. Since the testator is no longer around to clarify things, familial acrimonies have persisted among those left behind by virtue of la main mort, that is, the testator's will. Moreover, had it not been for the constraints that Andrés Bello encountered in Chile at the time of the passage of the Civil Code in 1855, little or nothing of the old system of inheritance stemming from Roman, and later Castilian law, ${ }^{438}$ would have been left. ${ }^{439}$

While it is true that the Civil Code kept the institution of the forced shares, ${ }^{440}$ as already mentioned, it limited them to one-half of the estate. ${ }^{441}$ That, in effect, did away with the old order of the families, under which the Western world had lived for about fifteen hundred years, under Pagan, and later Christianized Rome.

\section{Imposition Of A State Doctrine Based On The Principle OF UNIVERSALLY-MANDATED GOVERNMENT EDUCATION}

After the Revolution, the absolute State sought to perpetuate itself by means of the most effective of all means of control of society: the education of the minds. ${ }^{442}$ The Constitution of 1791 mandated that "public instruction

major accomplishment because two previous attempts in 1818 and 1828 had caused major unrest among landowners given this royal privilege during the colonial period. By converting the mayorazgos into rent-producing liquid assets, Bello was able to assure them that their property would not be lost. Clearly, Bello's interest in this matter was the elimination of privilege for the few while ensuring the sovereign character of private ownership. The principle of equality in civil (as distinct from political) terms was firmly established in such areas as the ability to acquire and dispose of property, and enter into contracts regardless of race, class, or national origin.").

${ }^{438}$ For a review of the Castilian succession law applicable to the colonies prior to their independence, see MIRow, supra note 346, at 61-69; see also CLIFFORd WALTON, THE CIVIL LaW IN Spain ANd Spanish-America 519-26 (2003).

${ }_{439}$ JAKSIĆ, supra note 6, at 169 ("Bello was not entirely satisfied with the ultimate outcome of legislation on succession, for he was an advocate of the freedom to designate beneficiaries in wills.").

440 Zweigert \& Kötz, supra note 56, at 96 (explaining that the forced shares that compose the estate is called reserve).

${ }_{441}$ See, e.g., Código CIVIL [COD. CIV.] arts. 1167, 1181, 1184 (Chile) (allowing the testator to devise in his last will and testament up to one-half of his estate).

442 See Hilaire Belloc, Survivals and New ARRIVAls 139 (speaking about the unwanted consequences befalling onto society in the name of a "universal compulsory educational 
for all citizens, free of charge in those branches of education which are indispensable to all men, shall be constituted and organized." ${ }^{, 43}$ The masses needed to be controlled, and education was the best antidote to avoid potential challenges to the new bourgeois order.

As lofty as the goals of universal education, or rather "instruction" 444 of the people were, the truth is that the mandate was and is intimately intertwined with content. The government mandates instruction, but only and exclusively in the substantive and topical programs determined by the government itself. As already stated elsewhere, whether a monarchy, aristocracy, autocracy, or democracy, the government does nothing for free. At the end of the day, the government ends up taxing parents and inculcating the content that it thinks is proper for children to learn, know, live by, and pass on to the next generation.

Besides content, governmental education focuses on intellectual formation and formal instruction, to the detriment of the holistic education of children based on values, aspiration, and ideals that only the family or a Church setting may provide. Even if well-intended, government-mandated education has caused a broad dereliction of parental obligations, at least in most of Latin America. By the end of the nineteenth century, leyes de instrucción primaria obligatoria (laws mandating primary education) and literacy programs swept through Latin America. ${ }^{45}$ Since education was thought to benefit society, and because it was the State's duty to avoid ignorance, the government would force children to attend school. ${ }^{446}$

In this sense, the Revolution claimed the totalizing power of the State in the present tense, but sought also to perpetuate itself by controlling the minds of future generations.

\footnotetext{
system").

${ }_{443} 1791$ ConST. tit. I (Fr.), available at http://sourcebook.fsc.edu/history/constitutionof 1791. html.

${ }^{444}$ BELloc, supra note 80, at 160 (recalling Danton saying that "after bread, the first need of the populace was instruction"); see also BELLOC, supra note 162, at 80 (stating, prophetically, "For instance, suppose a majority to order for all young children of the Modern State a certain course of instruction in certain sexual matters.").

445 Michael L. Kamil et al., 3 HandBoOK Of Reading Research 41 (2000) (referring to the spread of "literacy movements in Latin America").

446 GougH, supra note 14 (highlighting that the revolutionary agenda clearly included the replacement of the Christian religion by another religion built upon enlightened self-interest, called "Civic Education." For this purpose, in July 1793 the philosophical fanatics at the National Convention approved a plan for the creation of 20,000 boarding schools to provide compulsory education for boys from ages five to twelve. During this time they were to receive a strictly egalitarian education, all wearing the same clothes and receiving identical lessons, for them to become loyal citizens educated in Jacobin orthodoxy. This program eventually failed due to lack of funding, but not for lack of conviction).
} 


\section{A Legal Profession WITH LoOSE ETHICAL STANDARDS AND LAX ETHICS CONTROL MECHANISMS}

The legal profession is, literally more than figuratively, a survivor of the French Revolution. In fact, the Chapelier Law of 1791, in force until $1864,{ }^{447}$ reasoned that no mediators between the law and the citizens were needed. ${ }^{448}$ Accordingly, it abolished the profession of lawyer. ${ }^{449}$ Napoléon followed suit in his profound dislike for lawyers. ${ }^{450}$ In stark contradiction with the French Revolution's stance against lawyers and the right of representation by counsel, the ancien régime had afforded every litigant the opportunity to make use of an attorney. ${ }^{451}$

After the reinstatement of the profession of avocats, the legal profession survived, crippled, particularly in Latin America, under the broad influence of the Revolution. ${ }^{452}$ In that region, lawyers have been bred under the concept of legal positivism that teaches that the law is just and fair per se, that is, based on the mere fact that it emanates from the sovereign. ${ }^{453}$ However, in the many instances where the predicament of strict adherence to rigid notions of legal positivism is not fulfilled, the legal mind enters into an unsolvable conundrum. On the one hand, it is supposed to uphold the legal order, and on the other, it is a first-hand witness to the injustice of the law that it is supposed to defend. Whether the law is unfair or obsolete, the legal system and its professional oath still force judges and lawyers to apply it.

Precisely this detachment of the law from reality, and from what is fair, certain, and predictable, has widely caused lawyers to distrust the law as well. ${ }^{454}$ The road from distrust of the law, to disregard of the law, is a oneway street. In this scenario, considering that the judiciary is no longer trusted to impart justice, lawyers have habitually resorted to any means, some of them even clouded with illegality or illegitimacy, to obtain justice

\footnotetext{
447 BaSDEVANT-GAUdEMET \& GAUDEMET, supra note 51, at 391.

448 Id. at 348.

449 See VAN CAENEGEM, supra note 21 , at 131 (noting the expansion of the judge's role to create a more democratic access to justice for all).

${ }_{450}$ Lobingier, supra note 101 , at 124.

451 WATKIN, supra note 106, at 439 (highlighting that the right to counsel was instituted by the Ordonnance on civil procedure of 1667 ).

${ }^{452}$ Id . (commenting that post-Revolutionary France has supplied the structure and functions of the legal profession in much of the civil law world).

${ }^{453}$ See Código CIVIL [COD. CIV.] art. 1 (Chile), available at http://www.leychile.cl/Navegar ?idNorma $=172986$ (defining law as "a manifestation of the sovereign will").

${ }^{454}$ Maria Dakolias, A Strategy for Judicial Reform: The Experience in Latin America, 36 VA. J. INT'L L. 167, 168 (1995) ("A climate of distrust and frustration permeates the system and has been acknowledged by virtually every sector of society including private individuals, the business community and system insiders like judges and lawyers.").
} 
for their cases. ${ }^{455}$ The double allegiance of lawyers toward the law and their clients ended up generating great cynicism toward the legal system, or outright contempt for the law, in light of its unfairness or illegitimacy.

Furthermore, the legal profession well understands that its existence depends on the actions, reactions, and inactions of the political power. ${ }^{456}$ Its relations with the sovereign fluctuate, but the status and well-being of lawyers is ultimately reliant on the government. ${ }^{457}$ More than living, according to the rule of law, ${ }^{458}$ the legal profession has dwelled in postrevolutionary times in Latin America under the rule of the lawgiver. Thus, a legal profession with a very low self-esteem has been bred in Latin America, and this has happened thanks, in great measure, to the French Revolution.

\section{CONCLUSION}

Many theories attempt to explain away the flaws present in Latin American legal systems. Whatever the soundness of those explanations, the truth is that all the perceived weaknesses that linger in a society for whatever reason (wars, weather, wealth, or race) need a philosophical shape around which to consolidate themselves. These ideological underpinnings make it possible to write a Constitution and to draft laws that reflect the ethos of a people. The values that a society holds dear render it feasible to present a political project to the world based on philosophical foundations and not just on the dictatorial wimps of a ruler. In that sense, the French Revolution provided the catalyst for the new Latin American nations' failings upon their independence.

Experience and reason demonstrate that not every philosophical idea is correct or fair. The Revolutionary ideology is not the exception and it must be held accountable for the results it has provoked. ${ }^{459}$ That task has been

455 Maria Dakolias, The Judicial Sector in Latin America and the Cakibbean: ELEMENTS OF REFORM 62 (1996) ("[T] he punishments [of lawyers in Latin America] may be so minimal that enforcement does not deter unethical behavior by the lawyers.").

${ }^{456}$ See generally Rogelio PÉREZ-PERdomo, LATIN AMERICAN LAWYERS: A HiSTORICAL INTRODUCTION 42-48 (discussing the vicissitudes that Latin American lawyers have endured vis-à-vis the political power since the times of independence).

457 MERRYMAN \& PÉREZ-PERDOMO, supra note 69, at 1-19 (commenting on the challenges that the legal profession endures in post-Revolution Latin America); see also LUCAS SIERRA, Law, Social Change and Lawyers in Chile: From the Shrillness of THE 60s to The SILENCE OF TODAY (2002), available at http://law.yale.edu/documents/pdf/Law_Social_Chan ge_and_lawyers.pdf (discussing the relations between lawyers and the military regime during the military dictatorship of 1973-1990).

${ }_{458}$ JAKSIĆ, supra note 6, at 6-17 ("Therefore that rule is our true homeland, and that rule is the law, without which everything disappears.").

${ }^{459}$ For a discussion of the negative consequences brought throughout Europe by the French 
largely obscured, or is still pending with respect to Latin America. In this region, an implicit consensus across the board seems to exist in that only good fruits have emerged from the revolutionary seed. This paradigm needs to face history and reality and, consequently, change.

Certainly, ill "leanings" existed under Spanish colonial rule. For example, the most often overlooked legal obligation of encomenderos, to convert and educate the Indians, respect their customs, pay them their due, and protect and treat them as human beings. ${ }^{460}$ In fact, the Spanish Crown established the institution of the Protector of the Indians, to ensure their good treatment. ${ }^{461}$ Even if abolished, ${ }^{462}$ by the time of the independence movement, the old flavor of the enslavement of the Indians, which was illegal in the colonies, and sometimes carried out through the encomienda, still pervaded Latin American societies.

At any rate, all of these societal evils needed a philosophical shape, a substratum, to persist after independence, and they found it in the legal ideas spearheaded by the French Revolution.

The American constitutional experience shows that a strong system of check-and-balances counteracts abuses of power. ${ }^{463}$ As this Article posits, the French Revolution not only did not advance such a system, but it opposed it as a matter of principle.

Furthermore, there is an inherently discriminatory approach to equality in the French revolutionary ideas. Equality was not for everybody.

Revolution, see generally Edmund BurKe, Reflections on the Revolution IN France (1910)

${ }^{460}$ In the West, Catholic preachers were the first and foremost to cry foul on this old institution. See generally PAUL S. Vickery, 13 Bartolomé de las CASAS: Great Prophet of the Americas (2006); see also The Bull Sublimus Dei (ON the Enslavement and Evangelization of Indians IN THE New WORLD), of Pope PaUl III (1537) (putting the issue to rest when referring to the American Indians as "truly men ... [not to be] deprived of their liberty or the possession of their property... [to] freely and legitimately, enjoy their liberty [and not to be] in any way enslaved"). Protestant England, instead, never gave up slavery in the American colonies and neither did the Protestant Dutch in the Caribbean. The Catholic Medieval Age saw a gradual ascent from the slave to the serf and then to the free peasant. The Reformation undid all of this by first creating fertile ground for undeterred capitalism (the exploitation of the weak by the strong, in massive numbers), which in turn, generated the Communist response, which killed more human beings than any other doctrine in the past of humankind). Id.

461 RECOPILACIÓN DE LEYES DE LOS REYNOS DE LAS INDIAS (Andrés Ortega ed., 3d ed. 1774) (featuring Book VI, Title VI "De los Protectores de Indios") ("On the Protectors of the Indians" (author's translation)).

462 A royal cédula (decree) of 1721 by King Philip V, abolished definitively the encomienda system. MiRow, supra note 346, at 61-69.

463 Barbara A. Bardes et al., American Government and Politics today: The ESSENTIALS 89 (2008) (referring to the American model of vertical and horizontal check and balances system). 
Authoritarianism ran in tandem with the despising of the lower people. Rousseau, for example, the great inspirer of revolutionary legal ideas, admonished that private property was at the origin of all evils. In effect, Rousseau sustained that social evils began when the first man fenced a lot of land and claimed it for himself. ${ }^{464}$ Rousseau himself is supposed to have said "[y]ou forget that the fruits belong to all and that the land belongs to no one. ${ }^{, 465}$ However, taking a closer look at things, Rousseau not only twisted history, but neglected to notice that private property was not at the root of the social evils he described, but quite the opposite; the desire for accumulation of a few to the detriment of the right to private property by all is the true kernel of the phenomenon of accumulation. Ultimately, it was pride, the coveting of others' lands, that was at the source of all societal evils, and not the necessary and fundamental institution of private property.

Despite these contradictions, the Western world still lives under the aegis of the French Revolution, and many of its illnesses are patent today. Even the United States is not free from the influence of that movement. Thomas Jefferson, a friend, supporter, and promoter of the French revolutionaries, exalted the means and the ends of the Revolution early on when he said "that the revolution's glorious ends justified apocalyptic means. ${ }^{, 466}$ Jefferson, an unrepentant slave-owner, quickly accepted the revolutionary contempt toward the judiciary, and the fact that Marbury v. Madison occurred in the United States is despite or rather, against, his desires. ${ }^{467}$

464 Jean-JaCQues Rousseau, Discourse on the Origin and BaSis of INEQUality AMONG Men (Marc Michel Rey ed., 1754), cited in Peter Gay, The Basic Political Writings of JEAN JACQUES ROUSSEAU 25 (1987) ("The first man who, having fenced in a piece of land, said 'This is mine,' and found people naive enough to believe him, that man was the true founder of civil society.").

${ }^{465}$ M.A. Thiers, The History of the French Revolution 359 (Frederick Shoberl trans., 1877).

${ }^{466}$ Merrill Peterson, Jefferson Writings 1004 (14th ed. 1984). He also added, "[M]y own affections have been deeply wounded by some of the martyrs to the cause, but rather than it should have failed, I would have seen half the earth desolated." Id.

${ }_{467} \mathrm{John}$ Adams, a federalist in permanent political quarrel with and in opposition to Thomas Jefferson, wanted the judiciary to control the legislature, so he appointed his Secretary of State, John Marshall, as the Supreme Court Chief. Marshall, a federalist himself, used the first opportunity he had to assert the Supreme Court's power to control the constitutionality of the legislature, and issued the constitutional supremacy doctrine in Marbury v. Madison as an obiter dictum. In sum, the United States has enjoyed a democratic system based on the checkand-balances of the branches of government for two hundred years, and this, despite the Francophile Jefferson. His strong aversion toward the judiciary, his belief in a strong central government, the lack of check-and-balances, and the embracing of a revolutionary philosophy that profoundly distrusts the people, are still lingering threats to the American democratic experiment. See, e.g., Thomas Jefferson, Letter to Thomas Richie, 25 Dec. 1820, in WRITINGS OF THOMAS JEFFERSON 171 (Paul L. Ford ed. 1899) ("A judiciary independent of a king or executive along, is a good thing; but independent of the will of the nation is a solecism, at 
It is oftentimes pointed out that things in France followed a course of action different from that of Latin America, which has witnessed dictatorships and massive human rights violations. But a closer look at things bespeak otherwise. It would suffice to recall the casualties inflicted during the Napoleonic wars throughout Europe and elsewhere. Napoléon's Grande Armée alone lost more than three hundred thousand men during the invasion of Moscow in 1812. ${ }^{468}$ Napoléon's rise to power from Consul to dictator occurred in the spirit of, and thanks to, the Revolution's principle of strong separation of powers. Had the principle launched by the Revolution been otherwise, another fate would have befallen France, and Latin America in this case. In addition, many were massacred under the Vichy Regime during World War II. In summary, in just about two hundred years, millions lost their lives under the aegis of the French Revolution in Europe alone.

These events probably motivated France after World War II to revisit some of the liberal political principles it had lived by previously. But France was reluctant to recognize explicitly that those principles were wrong. Consequently, France started undoing some things that it had previously considered as carved in stone upon the Revolution. Significantly, it created a new court, the Constitutional Court, and refurbished the old royal State Council. However, it denied these tribunals the status of courts because, to do so, would have required denying the principle that judges do not have the power to strike down legislation, which is central to the whole idea of the separation of powers principle. In this evolution, the French also created a partial presidential veto power to control majorities. As the French were doing all of this after World War II, Latin Americans started looking at France anew to draw from the French legal wisdom. Consequently, Latin

least in a republican government."); Thomas Jefferson, Autobiography, 1821, in WRITINGS of THOMAS JefFERSON 113 (Paul L. Ford ed. 1899) ("They [the judges] are in fact the corps of sappers and miners, steadily working to undermine the independent rights of the States, and to consolidate all power in the hands of that government in which they have so important a freehold estate."); Thomas Jefferson, Letter to Charles Hammond, 18 Aug. 1821, in WritingS OF THOMAS JEFFERSON 331-32 (Andrew A. Lipscomb ed. 1904) ("The germ of dissolution of our federal government is in the constitution of the federal judiciary; an irresponsible body ... working like gravity by night and by day ... and advancing its noiseless step like a thief ... until all shall be usurped from the States and the government of all be consolidated into one."); Thomas Jefferson, Letter to A. Coray, 31 Oct. 1823, in WRITINGS OF THOMAS JEFFERSON 486-87 (Andrew A. Lipscomb ed. 1904) (calling the judiciary bodies "the most dangerous" members of "our government"). All citations are taken from THE OXFORD DictionaRY OF AMERICAN LEgAL QUOTATIONS 215 (Fred R. Shapiro ed., 1993).

${ }^{468}$ For a discussion of Napoléon's conquests, see FrEDERICK WHISHAW, MOSCOW: A STORY OF THE FRENCh INVASION OF 1812 (1905); THEODORE AYrault DOdGE, Napoleon's INVASION OF RUSSIA (2008); H.B. GEORGE, NAPOLEON'S INVASION OF RUSSIA (1899); R.G. BURTON, NAPOLEON'S INVASION OF RUSSIA (1914). 
American governments began implementing other French experiments without pondering the advisability of the very intellectual bases of their own constitutional and legal systems.

The question that begs now is: quo vadis (what happens now)? As it was advanced in the introduction, the purpose of this essay has been destructive, that is, aimed at exposing and demolishing the legal legacy of a philosophical and political movement that, at least in the context of Latin America, has largely exceeded its lifespan. The next chapter of this saga would be to propose an alternative model or framework, a different intellectual and philosophical foundation, which would provide sounder legal bases for Latin American societies. That task must be left for another, maybe better, day. Hopefully, not more than another two hundred years shall elapse until that happens. 